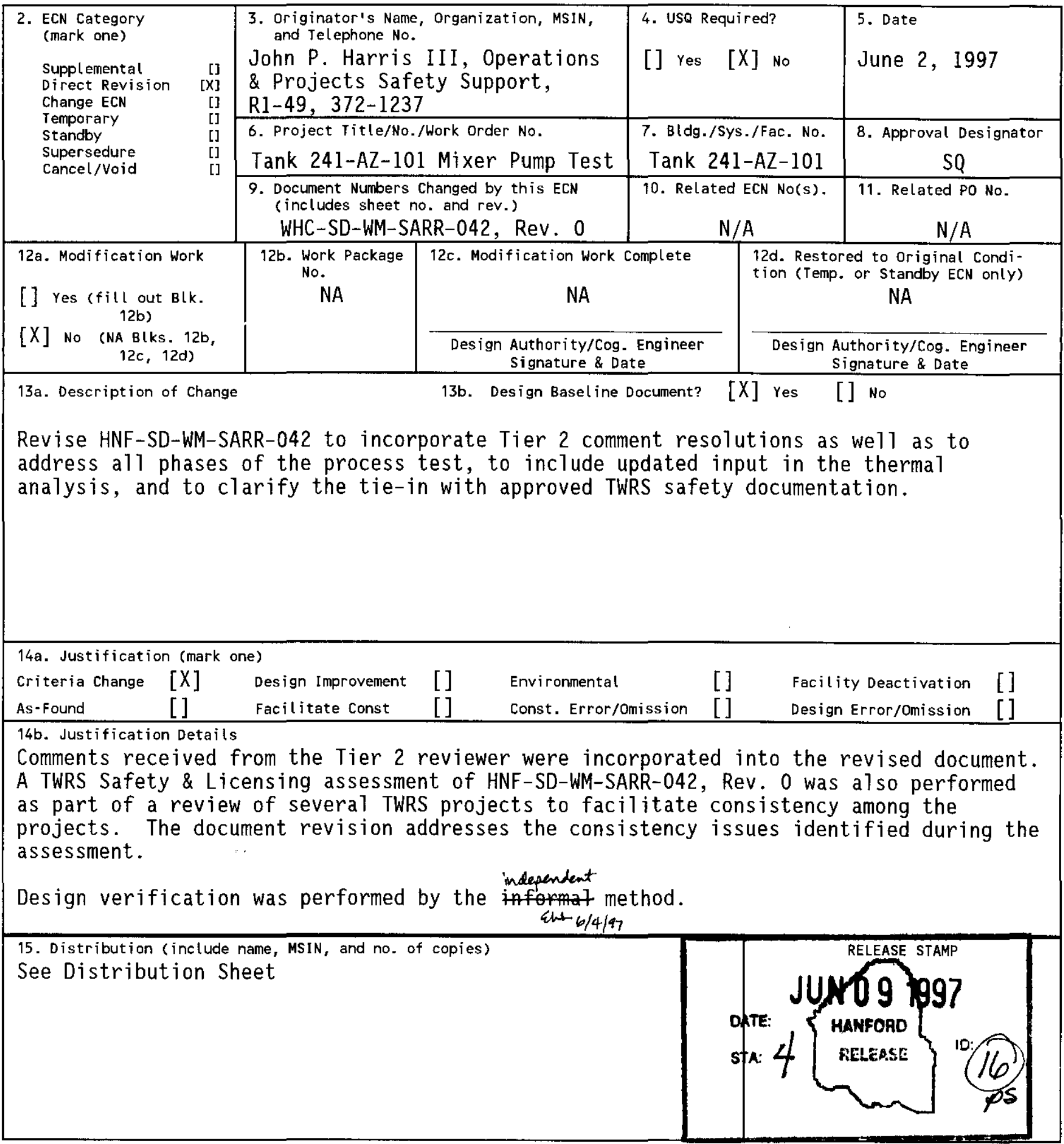









\section{Safety Analysis for Tank 241-AZ-101 Mixer Pump Process Test}

D. M. Hammond, J. P. Harris III, P. Mouette

Duke Engineering \& Services Hanford Company, Richland, WA 99352

U.S. Department of Energy Contract DE-AC06-96RL13200

$\begin{array}{lll}\text { EDT/ECN: } & 635108 & \text { UC: } 2020 \\ \text { Org Code: } & 2 \text { N140 } & \text { Charge Code: } \\ \text { B\&R Code: } & 39 E W 31301 & \text { Total Pages: } 159\end{array}$

Key Words: Mixer pumps, 101-AZ, process test, safety analys is

Abstract: This document contains the completed safety analys is which establishes the safety envelope for performing the mixer pump process test in Tank 241-AZ-101. This process test is described in TF-210-0TP-001. A11 equipment necessary for the mixer pump test has been installed by Project $W-151$.

ENRAF $^{T M}$ is a trademark of ENRAF, Incorporated.

EPI code - is is a trademark of Homann Associates, Inc.

TRADEMARK DISCLAIMER. Reference herein to any specific commercial product, process, or service by trade name, trademark, manufacturer, or otherwise, does not necessarily constitute or imply its endorsement, recommendation, or favoring by the United States Government or any agency thereof or its contractors or subcontractors.

Printed in the United States of America. To obtain copies of this document, contact: WHC/BCS Document Control Services, P.O. Box 1970, Mailstop H6-08, Richland WA 99352, Phone (509) 372-2420; Fax (509) 376-4989.
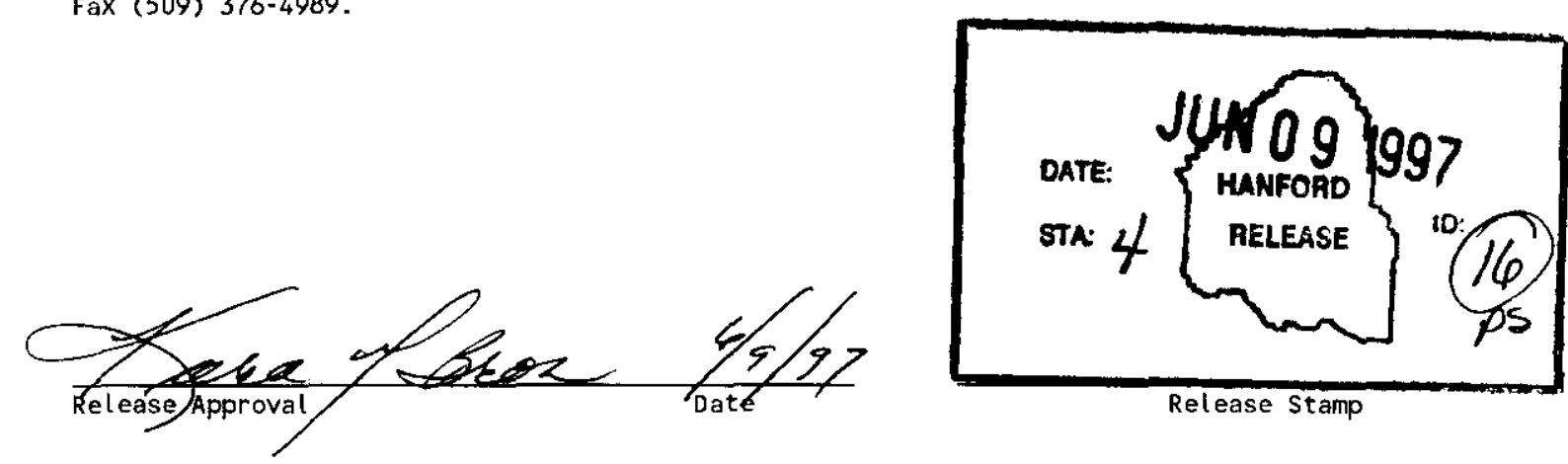

Approved for Public Release 
(2) Title

Safety Analysis for Tank 241-AZ-101 Mixer Pump Process Test

CHANGE CONTROL RECORD

\begin{tabular}{|c|c|c|c|}
\hline \multirow{2}{*}{ Revision } & \multirow{2}{*}{ (4) Description of Change - Replace, Add, and Delete Pages } & \multicolumn{2}{|c|}{ Authorized for Release } \\
\hline & & (5) Cog. Engr. & (6) Cog. Mgr. \\
\hline 0 & $\begin{array}{l}\text { (7) Intial release of safety analys is } \\
\text { report reference. (EDT } 614545 \text { ) }\end{array}$ & GR Tardiff & GN Hanson $8 / 22 / 96$ \\
\hline RS 1 & $\begin{array}{l}\text { Revised document to incorporate Tier } 2 \\
\text { comments as well as changes due to TWRS } \\
\text { Safety \& Licensing assessment. ECN } 635108\end{array}$ & $\begin{array}{l}\text { GR Tardiff } \\
\text { Ent for GRT } \\
(\text { Sec ECN })\end{array}$ & $\begin{array}{l}\text { DG Baide } \\
\text { ahd for } \\
\qquad D B(\sec E C N) / 9 / 97\end{array}$ \\
\hline & & & \\
\hline & & & \\
\hline & & & \\
\hline & & & \\
\hline & & & \\
\hline & & & \\
\hline & & & \\
\hline & & & \\
\hline & & & \\
\hline & & & \\
\hline & & & \\
\hline & & & \\
\hline & & & \\
\hline & & & \\
\hline & & & \\
\hline & & & \\
\hline & & & \\
\hline & & & \\
\hline & & & \\
\hline & & & \\
\hline & & & \\
\hline & & & \\
\hline & & & \\
\hline & & & \\
\hline & & & \\
\hline & & & \\
\hline & & & \\
\hline & & & \\
\hline & & & \\
\hline & & & \\
\hline
\end{tabular}


HNF-SD-WM-SARR-042 REV 1

This page intentionally left blank. 


\section{CONTENTS}

EXECUTIVE SUMMARY

1.0 SITE CHARACTERISTICS . . . . . . . . . . . . . . 1-1

1.1 INTRODUCTION ....................... . . . . . . . . .

1.2 REQUIREMENTS . . . . . . . . . . . . . . . . . . 1-1

1.3 SITE DESCRIPTION . . . . . . . . . . . . . . . . 1-1

1.4 ENVIRONMENTAL DESCRIPTION . . . . . . . . . . . . . . . . . . . 1-1

1.5 NATURAL PHENOMENA THREATS ................ . . . 1-1

1.6 EXTERNAL MAN-MADE THREATS . . . . . . . . . . . . 1-2

1.7 NEARBY FACILITIES ................. . . . . . . . . . . .

1.8 VALIDITY OF EXISTING ENVIRONMENTAL ANALYSES . . . . . . . . . $1-2$

2.0 FACILITY DESCRIPTION . . . . . . . . . . . . . 2-1

2.1 INTRODUCTION ................... . . . . . . . . . . .

2.2 REQUIREMENTS .................. . . . . . . . . . .

2.3 FACILITY OVERVIEW . . . . . . . . . . . . . . . . . 2-2

2.4 FACILITY STRUCTURE . . . . . . . . . . . . . . . 2-2

2.5 PROCESS DESCRIPTION ............... . . 2-5

2.5.1 Mixer Pump Testing . . . . . . . . . . . 2-5

2.6 CONFINEMENT SYSTEMS $\ldots \ldots \ldots$

2.6.1 241-AY and 241-AZ (Aging Waste Facility) Tank Farm Ventilation System - Project W-030 ...... 2-6

2.6.2 241-AY and 241-AZ (Aging Waste Facility) Tank Farm Ventilation System - 241-A-702 ........ . 2-7

2.6.3 Annulus Exhaust Flow Description . . . . . . . . . 2-7

2.7 SAFETY SUPPORT SYSTEMS . . . . . . . . . . . . . . 2-7

2.7.1 Existing Equipment . . . . . . . . . . . . 2-7

2.7.1.1 Liquid Level Measurement System . . . . . . . . 2-7

2.7.1.2 Temperature Monitoring . . . . . . . . 2-8

2.7.1.3 Hydrogen Monitoring . . . . . . . . . . . . 2-8

2.7.1.4 Tank Pressure Monitoring . . . . . . . . 2-8

2.7.1.5 Process Air System . . . . . . . . . . 2-9

2.7.2 Tank 241-AZ-101 Mixer Pump System Equipment .... 2-10

2.8 UTILITY DISTRIBUTION SYSTEMS . . . . . . . . . . . . . . . 2-13

2.8.1 Water Supply Systems . . . . . . . . . . . . 2-13

2.8.2 Electric Power Systems . . . . . . . . . . . 2-13

2.9 AUXILIARY SYSTEMS AND SUPPORT FACILITIES . . . . . . . . 2-13

3.0 HAZARD AND ACCIDENT ANALYSIS ............ . . 3-1

3.1 INTRODUCTION . . . . . . . . . . . . . . . . . . $3-1$

3.2 REQUIREMENTS .................... . . . . . . . . . . .

3.3 HAZARDS ANALYSIS . . . . . . . . . . . . . . 3-2

3.3.1 Methodology . . . . . . . . . . 3-2

3.3.1.1 Hazard Identification .......... . 3-2

3.3.1.2 Hazard Evaluation ............. . 3-2

3.3.1.3 Worker Health and Safety Requirements . . . . . 3-2

3.3.2 Hazard Analysis Results .............. 3-3

3.3.2.1 Hazard Identification . . . . . . . . . 3-3

3.3.2.2 Hazard Classification . . . . . . . . . 3-3

3.3.2.3 Hazard Evaluation .. . . . . . . . . . 3-3

3.3.2.4 Accident Selection .......... . 3-4 


\section{CONTENTS (Cont)}

3.4 ACCIDENT ANALYSIS . . . . . . . . . . . . . . 3-7

3.4.1 Methodology ........ . . . . . . . . . .

3.4.1.1 Radiological Consequence Calculation

Methodology .......... 3-8

3.4.1.2 Toxicological Consequence Calculation

Methodology . . . . . . . . . . . . . 3-10

3.4.2 Design Basis Accidents . . . . . . . . . . . . 3-12

3.4.2.1 Unfiltered Release of Radionuclides and Toxic Aerosols From the Tank . . . . . . . . . 3-12

3.4.2.2 Tank Bump Accident . . . . . . . . . . . . 3-25

3.4.2.3 Breach of Containment . . . . . . . . . 3-30

3.4.2.4 Criticality .......... . . 3-38

3.4.3 Beyond Design Basis Accidents . . . . . . . . 3-40

4.0 SAFETY SYSTEMS, STRUCTURES, AND COMPONENTS . . . . . . . . . 4-1

5.0 DERIVATION OF TECHNICAL SAFETY REQUIREMENTS ........ 5-

6.0 PREVENTION OF INADVERTENT CRITICALITY . . . . . . . . . . . . 6-1

6.1 REQUIREMENTS ................. . . . . . . . . .

6.2 FACILITY IMPLEMENTATION . . . . . . . . . . . . . . . 6-1

6.3 PROJECT IMPLEMENTATION ................. . . . . . . .

7.0 RADIATION PROTECTION . . . . . . . . . . . . . 7-1

7.1 REQUIREMENTS .................. . . . . . . . . . . .

7.2 FACILITY IMPLEMENTATION . . . . . . . . . . . . . . . . 7-1

7.3 PROJECT IMPLEMENTATION ................. . . . . . . .

8.0 HAZARDOUS MATERIAL PROTECTION . . . . . . . . . . . . 8-1

8.1 REQUIREMENTS ................. . . . . . . . . . . .

8.2 FACILITY IMPLEMENTATION . . . . . . . . . . . . . . . . 8-1

8.3 PROJECT IMPLEMENTATION ................. . . . . . . . .

9.0 RADIOACTIVE AND HAZARDOUS WASTE MANAGEMENT . . . . . . . . . . . . 9-1

9.1 REQUIREMENTS . . . . . . . . . . . . . . . . . . . . . . 9-1

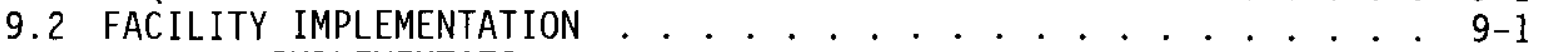

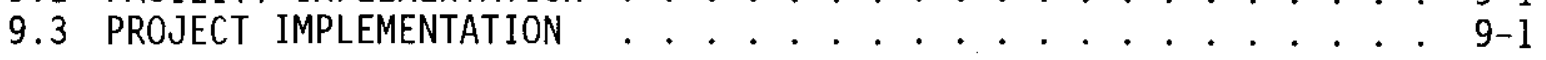

10.0 INITIAL TESTING, IN-SERVICE SURVEILLANCE, AND MAINTENANCE . . . . 10-1

10.1 REQUIREMENTS . . . . . . . . . . . . . . . 10-1

10.2 FACILITY IMPLEMENTATION $\ldots \ldots \ldots$. . . . . . . . . 10-1

10.3 PROJECT IMPLEMENTATION . . . . . . . . . . . . . . . . 10-1

10.3.1 Initial Testing ........... . . 10-1

10.3.2 In-Service Surveillance . . . . . . . . . . . 10-1

10.3.3 Maintenance . . . . . . . . . . . . 10-1

11.0 OPERATIONAL SAFETY . . . . . . . . . . . . . . . 11-1

11.1 REQUIREMENTS . . . . . . . . . . . . . . . 11-1

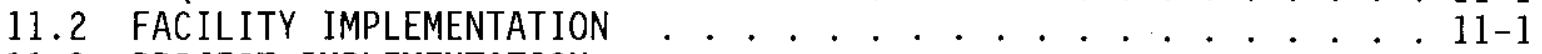

11.3 PROJECT IMPLEMENTATION . . . . . . . . . . . . . . 11-1 


\section{CONTENTS (Cont)}

12.0 PROCEDURES AND TRAINING ............... . . . . . .

12.1 REQUIREMENTS . . . . . . . . . . . . . . . . . . . . 12-1

12.2 FACILITY IMPLEMENTATION . . . . . . . . . . . . . 12-1

12.3 PROJECT IMPLEMENTATION . . . . . . . . . . . . 12-1

13.0 HUMAN FACTORS ............... . . . . . . . .

13.1 REQUIREMENTS . . . . . . . . . . . . . . . . . . . . . . . . . 13-1

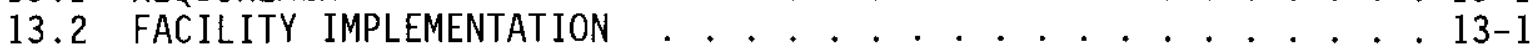

13.3 PROJECT IMPLEMENTATION . . . . . . . . . . . . . 13-1

14.0 QUALITY ASSURANCE . . . . . . . . . . . . . . 14-1

14.1 REQUIREMENTS . . . . . . . . . . . . . . . . . . 14-1

14.2 FACILITY IMPLEMENTATION $\ldots \ldots \ldots$. . . . . . . . . . 14-1

14.3 PROJECT IMPLEMENTATION . . . . . . . . . . . . . . 14-1

15.0 EMERGENCY PREPAREDNESS PROGRAM . . . . . . . . . . . 15-1

15.1 REQUIREMENTS ................... . . . . . . . . . . .

15.2 FACILITY IMPLEMENTATION . . . . . . . . . . . 15-1

15.3 PROJECT IMPLEMENTATION . . . . . . . . . . . . . . . 15-1

16.0 PROVISIONS FOR DECONTAMINATION AND DECOMMISSIONING . . . . . . 16-1

16.1 REQUIREMENTS . . . . . . . . . . . . . . . . . . . 16-1

16.2 FACILITY IMPLEMENTATION .................. . . . . . . . . . .

16.3 PROJECT IMPLEMENTATION . . . . . . . . . . . . . . . 16-1

17.0 MANAGEMENT, ORGANIZATION, AND INSTITUTIONAL SAFETY PROVISIONS . . 17-1

17.1 REQUIREMENTS .................. . . . . . . . . . . .

17.2 FACILITY IMPLEMENTATION $\ldots \ldots \ldots$

17.3 PROJECT IMPLEMENTATION . . . . . . . . . . . . . . 17-I

18.0 REFERENCES . . . . . . . . . . . . . . . . . 18-1

18.1 DOCUMENTS . . . . . . . . . . . . . . . . . . . . . .

18.2 U.S. DEPARTMENT OF ENERGY ORDERS, STANDARDS, AND HANDBOOKS . . 18-6

18.3 U.S. ENVIRONMENTAL PROTECTION AGENCY . . . . . . . . . . . . . 18-6

18.4 WESTINGHOUSE HANFORD COMPANY CONTROLLED MANUALS . . . . . . 18-6

18.5 NUCLEAR REGULATORY COMMISSION . . . . . . . . . . . 18-6 


\section{LIST OF FIGURES}

2-1 Top-view of Tank 241-AZ-101 . . . . . . . . . . 2-4

\section{LIST OF TABLES}

ES-1 Summary of Accident Consequences ... . . . . . . . . . . ES-5

ES-2 Summary of Preventive/Mitigative Actions . . . . . . . . . . ES-6

2-1 Project W-151 Mixer Pump Characteristics . . . . . . . . . . . . 2-5

3-1 Accident SeTection and Mapping to Analysis . . . . . . . . . 3-6

3-2 Radiological Risk Evaluation Guidelines . . . . . . . . . . . . 3-7

3-3 Toxicological Risk Evaluation Guidelines ........... . 3-7

3-4 Centerline Atmospheric Dispersion Coefficients . . . . . . . . . 3-8

3-5 Chronic Annual Average Atmospheric Dispersion Coefficients for 200 Area Tank Farms . . . . . . . . . . . . . . . 3-8

3-6 In-Tank Concentration of the 11 Radionuclides Chosen for Inclusion in Accident Analysis . . . . . . . . . . . . . . . . . . . 3-9

3-7 Unit Liter Doses for Inhalation and Ingestion........ 3-9

3-8 Release Durations for which the Maximum Puff $x / Q$ can be Applied . . 3-10

3-9 Tank Waste Liquids and Solids Analyte Concentrations ..... . . 3-11

3-10 Sum-of-Fractions for Risk Evaluation Guidelines for a Unit Release of Waste Chemicals . . . . . . . . . . . . . . 3-12

3-11 Radiological and Toxicological Consequences of a HEPA Filter Failure Due to Over-Pressure Accident, with Comparison to Risk Guidelines . . . . . . . . . . . . . . . . . 3-24

3-12 Tank bump Radiological and Toxicological consequences . . . . . 3-28

3-13 Radiological and Toxicological Consequences of a Flammable Gas Deflagration ............. . . . . . 3-32

5-1 Summary of Preventive/Mitigative Actions ......... . 5-2

\section{APPENDICES}

3.A HAZARDS AND OPERABILITY STUDY FOR PROJECT W-15l ...... 3 3-1 3.B HAZARDS ANALYSIS SUMMARY ............... 3B-1 


\section{LIST OF TERMS}

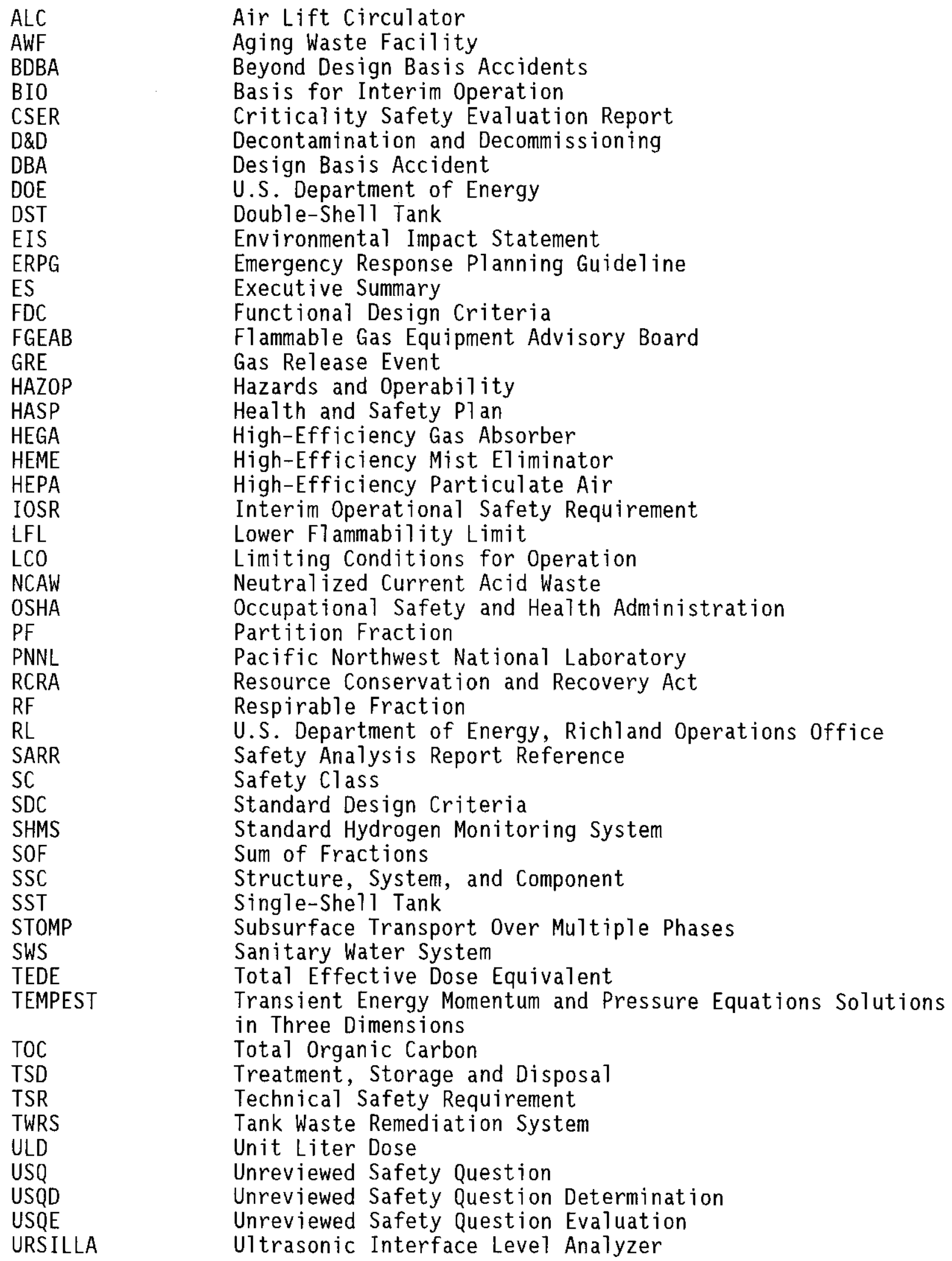


HNF-SD-WM-SARR-042 REV 1

This page intentionally left blank. 
HNF-SD-WM-SARR-042 REV 1

\section{EXECUTIVE SUMMARY}

\section{ES. 1 FACILITY BACKGROUND AND MISSION}

The purpose of this document is to describe and analyze the mixer pump test for Aging Waste Facil ity (AWF) Tank 241-AZ-101 and to address the "yes/maybe" responses marked for evaluation questions identified in Unreviewed Safety Question Evaluation (USQE) TF-94-0266. The scope of this document is limited to the performance of the mixer pump test for Tank 241-AZ-101. Unreviewed Safety Question Determination (USQD) TF-96-0018 verified that the installation of two mixer pumps into Tank 241-AZ-101 was within the current Tank Waste Remediation System (TWRS) Authorization Basis. USQDS TF-96-0461, TF-96-0448, and TF-96-0805 verified that the installation of the in-tank video camera, thermocouples, and Ultrasonic Interface Level Analyzer (URSILLA), respectively, were within the current TWRS Authorization Basis. USQD TF-96-1041 verified that the checkout testing of the installed equipment was within the current TWRS Authorization Basis. Installation of the pumps and equipment has been completed. An evaluation of safety considerations associated with operation of the mixer pumps for the mixer pump test is provided in this document. This document augments the existing AWF authorization basis as defined in the Interim Safety Basis (Stah1 1997), and as such, will use the existing Interim Operational Safety Requirements (IOSRs) of Heubach 1996 to adequately control the mixer pump test. The hazard and accident analysis is limited to the scope and impact of the mixer pump test, and therefore does not address hazards already addressed by the current AWF authorization basis. 
This document does not evaluate removal of the mixer pumps. Safety considerations for removal of the pumps will be addressed by separate safety documentation once that portion of the mission is defined. The mixer pump test has been evaluated to cover the use of either the existing ventilation system (241-A-702) or the ventilation system upgrade provided by Project $W-030$. Analysis of Project $W-030$ is outside of the scope of this document and is addressed in HNF-SD-WM-SARR-039 (Draft) which, should the W-030 system be in service at the time of the mixer pump test, will have been approved and made a part of the TWRS authorization basis.

The test will use two high-capacity mixer pumps in various configurations and modes to demonstrate solids mobilization of waste in Tank 241-AZ-101. The information and experience gained during the test will provide data for comparison with sludge mobilization prediction models; provide data to estimate the number, location, and cycle times of the mixer pumps; and provide indication of the effects of mixer pump operation on the AWF tank systems and components. The slurry produced will be evaluated for future pretreatment processing. This process test does not transfer waste from the tank; the waste is mixed and confined within the existing system. At the completion of the mixer pump test, the mixer pumps will be stopped and normal tank operations, maintenance, and surveillance will continue. Periodic rotation of the mixer pumps and motor shafts, along with bearing greasing, is required to maintain the pumps following the mixer pump test. 


\section{ES. 2 FACILITY OVERVIEW}

An overview of the AWF, including a description of the facility mission and stage of 1 ife-cycle, is provided in the TWRS Basis for Interim Operations (BI0) WHC-SD-WM-BI0-001, Rev 0. The TWRS BIO was approved on May 30, 1997 (Piper 1997). General TWRS and Hanford Site information is provided via reference to the approved TWRS BIO. Likewise, specific information pertaining to the AWF tanks is provided via reference to the approved TWRS BIO. Aspects of the mixer pump test and facility test configuration relevant to this safety evaluation are documented in Chapter 2.

\section{ES. 3 FACILITY HAZARD CLASSIFICATION}

TWRS facilities, including the AWF, have been designated as Hazard Category 2 facilities (Table 5.1-1 of the TWRS BI0). The mixer pump test does not impact the Hazard Classification assumptions of Tank 241-AZ-101 (no change to the inventory or amount of the material at risk). Thus, Tank 241-AZ-101 remains classified as Hazard Category 2.

\section{ES. 4 SAFETY ANALYSIS OVERVIEW}

Hazards associated with operation were evaluated using process hazard analysis and Hazards and Operability (HAZOP) evaluation techniques. From the results of the hazard analysis, six postulated events were identified as representative of the significant hazards. These events are: (1) a ventilation system high-efficiency particulate air (HEPA) filter failure, (2) backflow through open tank riser, (3) leakage via failed vent ducting, (4) a breach of the tank due to internal or external mechanisms, (5) a nuclear 
criticality induced by mixer pump operation, and (6) a seismic event. These postulated events were evaluated, based on specific causes and conditions associated with the mixer pump test as described in Section 3.3.2.4. This evaluation resulted in the identification of four design basis accidents that are analyzed in Section 3.4.2. These accidents are: (1) unfiltered release of radionuclide and toxic aerosols from the tank, (2) tank bump, (3) breach of containment, and (4) over-pressurization caused by criticality. The various causes and conditions associated with each of these accident scenarios are identified in Table 3-1. A summary of the accident consequences and a comparison to the risk evaluation guidelines are provided in Table ES-1. A summary of the preventive and mitigative features is provided in Table ES- 2 . 
Table ES-1 Summary of Accident Consequences

\begin{tabular}{|c|c|c|c|c|c|}
\hline \multirow[b]{2}{*}{ Design Basis Accident Scenario } & \multicolumn{4}{|c|}{ Mixer pump test Design Basis Accident consequences } & \multirow{2}{*}{$\begin{array}{l}\text { Risk } \\
\text { evaluation } \\
\text { guidelines }\end{array}$} \\
\hline & & & \begin{tabular}{|c|} 
without \\
prevention/ \\
mitigation
\end{tabular} & $\begin{array}{l}\text { with } \\
\text { prevention/ } \\
\text { mitigation* }\end{array}$ & \\
\hline \multicolumn{6}{|c|}{ Unfiltered release of radionuclides or toxic aerosols (Section 3.4.2.1) } \\
\hline \multirow{4}{*}{$\begin{array}{l}\text { HEPA filter faiture due to over- } \\
\text { pressure } \\
\text { (Section } 3.4 \cdot 2.1 .2 \text { ) } \\
\text { Frequency: EU }\end{array}$} & \multirow[t]{2}{*}{ Radiological (rem) } & Offsite & ** & $3.8 \mathrm{E}-3$ & 4 \\
\hline & & Onsite & ** & 2.7 & 10 \\
\hline & \multirow[t]{2}{*}{ Toxicological (SOF) } & Offsite & ** & $2.6 E-5$ & 1 (ERPG-2) \\
\hline & & Onsite & ** & $3.3 \mathrm{E}-1$ & 1 (ERPG-3) \\
\hline $\begin{array}{l}\text { Reverse flow through tank due to } \\
\text { tank dome collapse and breach of } \\
\text { conf inement (Sect ion } 3.4 .2 .3 .6 \text { ) } \\
\text { Frequency: BEU (See Breach of } \\
\text { Containment) }\end{array}$ & $\begin{array}{l}\text { This event is determined to } \\
\text { be beyond extremely unl ikely } \\
\text { for mixer pump test. }\end{array}$ & $\begin{array}{l}\text { offsite } \\
\text { and } \\
\text { Onsite }\end{array}$ & None & N/A & N/A \\
\hline \multirow{4}{*}{$\begin{array}{l}\text { Tank Bump (Section } 3.4 .2 .2) \\
\text { Frequency: } U\end{array}$} & \multirow[t]{2}{*}{ Radiological (rem) } & Offsite & .22 & None & 0.5 \\
\hline & & Onsite & 250 & None & 5 \\
\hline & \multirow[t]{2}{*}{ Toxicological (SOF) } & Offsite & .73 & None & 1 (ERPG-1) \\
\hline & & Onsite & $4.9 E+03$ & None & 1 (ERPG-2) \\
\hline \multicolumn{6}{|c|}{ Breach of containment (Section 3.4.2.3) } \\
\hline \multirow{4}{*}{$\begin{array}{l}\text { Flammable Gas } \\
\text { Deflagration } \\
\text { (Section } 3.4 .2 .3 .1 \text { ) } \\
\text { Frequency: Accident prevented } \\
\text { through Wicks et al. 1997. Open } \\
\text { USQ prevents quant ification. } \\
\text { Natural phenomena frequencies } \\
\text { probably drive this to EU. }\end{array}$} & \multirow[t]{2}{*}{ Radiological (rem) } & offsite & 0.004 & None & $\operatorname{TBD}^{\star \star \star \star}$ \\
\hline & & Onsite & 4.4 & None & 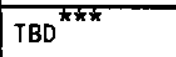 \\
\hline & \multirow[t]{2}{*}{ Toxicological (SOF) } & Offsite & 0.7 & None & 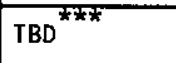 \\
\hline & & Onsite & 820 & None & 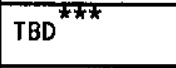 \\
\hline $\begin{array}{l}\text { Tank Dome Coll lapse (Section } \\
3.4 .2 .3 .6 \text { ) } \\
\text { Frequency: BEU }\end{array}$ & $\begin{array}{l}\text { This event determined to be } \\
\text { BEU for mixer pump test } \\
\text { structural loadings. }\end{array}$ & $\begin{array}{l}\text { Offsite } \\
\text { and } \\
\text { Onsite }\end{array}$ & None & N/A & N/A \\
\hline $\begin{array}{l}\text { Seismic during pumps operation } \\
\text { (Section } 3.4 .2 .3 .7 \text { ) } \\
\text { Frequency: BEU }\end{array}$ & $\begin{array}{l}\text { Analys is shows that pump } \\
\text { support and riser } \\
\text { conf iguration acceptable for } \\
\text { appl ied design requirements. }\end{array}$ & $\begin{array}{l}\text { Offsite } \\
\text { and } \\
\text { Onsite }\end{array}$ & None & N/A & N/A \\
\hline $\begin{array}{l}\text { Material degradation due to high } \\
\text { temperature } \\
\text { (Section } 3.4 .2 .3 .5 \text { ) } \\
\text { Erosion (Section } 3.4 .2 .3 .4 \text { ) } \\
\text { Missiles from the pumps (section } \\
3.4 .2 .3 .3 \text { ) } \\
\text { Frequencies: BEU }\end{array}$ & $\begin{array}{l}\text { Analyses show that these } \\
\text { events are prevented and not } \\
\text { credible. }\end{array}$ & $\begin{array}{l}\text { offsite } \\
\text { and } \\
\text { Onsite }\end{array}$ & None & $\overline{N / A}$ & $N / A$ \\
\hline $\begin{array}{l}\text { Criticality } \\
\text { (Section } 3.4 .2 .4 \text { ) } \\
\text { Frequency: BEU }\end{array}$ & $\begin{array}{l}\text { This event determined to be } \\
\text { BEU for mixer pump test. }\end{array}$ & $\begin{array}{l}\text { Offsite } \\
\text { and } \\
\text { Onsite }\end{array}$ & None & $\begin{array}{l}\text { N/A (no } \\
\text { preventive } \\
\text { or } \\
\text { mitigative } \\
\text { features } \\
\text { identified) }\end{array}$ & N/A \\
\hline
\end{tabular}

* Rrevention/mitigation listed in Table ES 2 .

* See Section 3.4.2.1.2.1 for discussion of unmitigated consequences.

TBD = To Be Determined. (After closure of Serrano 1996 allows quantification.)

$A=$ anticipated $(1 / \mathrm{yr}-102 / \mathrm{yr})$

$B E U=$ beyond extremely unl ikely $\left(\leq 10^{-6}\left(y^{r}\right)\right.$

EU = extremely unlikely $\left(10^{-4} / \mathrm{yr}-10^{-6 / y r}\right)$

$U=$ unl ikely $\left(10^{-2} / \mathrm{yr}-10^{-4} / \mathrm{yr}\right)$

$N / A=$ not applicable

SOF $=$ sum of fractions 
Table ES-2 Summary of Preventive/Mitigative Actions

\begin{tabular}{|c|c|c|}
\hline Accident Scenario & Preventive or Mitigative Actions during mixer pump test & $\begin{array}{l}\text { Applicable IOSR or } \\
\text { Other Control } \\
\text { Document }\end{array}$ \\
\hline $\begin{array}{l}\text { Unfiltered release of } \\
\text { radionucl ides and toxic } \\
\text { aerosols from the tank } \\
\text { (Section } 3.4 .2 .1 \text { ) }\end{array}$ & $\begin{array}{l}\text { Limiting the maximum activity on each filter to a level } \\
\text { that gives an equivalent dose rate of } 200 \mathrm{mrem} / \mathrm{h} \text { on contact } \\
\text { controls the amount of particulates that could be expelled. }\end{array}$ & $\begin{array}{l}\text { LCO } 3.4 .3 \\
\text { AWF IOSRS }\end{array}$ \\
\hline $\begin{array}{l}\text { Tank Bump } \\
\text { (Sect } i \text { on } 3.4 .2 .2 \text { ) }\end{array}$ & $\begin{array}{l}\text { - LCO } 3.4 .1 \text { requires ventilation operability to prevent tank } \\
\text { pressurization and an unfiltered release. Operation of the } \\
\text { vent system also provides a cooling mechanism to remove the } \\
\text { heat input due to mixer pump operation. } \\
\text { - sludge movement caused by mixer pump operation may build } \\
\text { up sludge to } 64 \mathrm{~cm} \text { ( } 25-\text { in.) or more under ALCs and tend to } \\
\text { plug them. Adjacent ALCs, as appropriate, will be operated } \\
\text { to remove sludge from around the affected ALC. Sludge } \\
\text { buildup will be monitored during the test to determine when, } \\
\text { and which, ALCs should be started (per Ross 1997). } \\
\text { - Upon loss of the primary ventilation system and backup the } \\
\text { mixer pump(s) will be turned off to control gas and heat } \\
\text { buildup in the tank. The primary ventilation recovery times } \\
\text { ( } 40 \text { hours when ALCs are not required and } 16 \text { hours when ALCs } \\
\text { are required per LCo } 3.4 .4 \text { ) are unchanged for the mixer pump } \\
\text { test. } \\
\text { - During normal operation of the pump(s) and at the end of } \\
\text { the test while the pumps are turned off, the waste } \\
\text { temperature will be monitored and the Air Lift Circulators } \\
\text { operated as soon as the temperature reaches } 230 \text { of for sludge } \\
\text { and/or } 200 \text { of for liquid. }\end{array}$ & $\begin{array}{l}\text { LCO } 3.4 .1 \text {, } \\
\text { AWF IOSRS } \\
\text { LCO } 3.4 .4 \\
\text { AWF IOSRs } \\
\\
\text { LCO } 3.4 .1 \\
\text { AWF IOSRS } \\
\\
\text { LCO } 3.4 .4 \\
\text { AWF IOSRS }\end{array}$ \\
\hline $\begin{array}{l}\text { Breach of Containment } \\
\text { (Section } 3.4 .2 .3 \text { ) }\end{array}$ & $\begin{array}{l}\text { - High temperature (3.4.2.3.5) : } \\
\text { - Primary and backup tank exhaust ventilation systems } \\
\text { shall be operable with one system operating. } \\
\text { - The primary tank waste temperature shall be } \\
\text { maintained } \leq 300{ }^{\circ} \mathrm{F} \text { and all heat generating equipment } \\
\text { (e.g., mixer pumps) shut off if this temperature is } \\
\text { reached } \\
\text { - Flammable gas deflagration ( } 3.4 .2 .3 .1) \text { : } \\
\text { - Implementation of Ignition source Control as well } \\
\text { as monitoring for flammable gas is a preventive } \\
\text { measure against deflagration and breach of the tank } \\
\text { and ventilation confinement in the event that an } \\
\text { episodic gas release exceeds } 100 \% \text { of the lower } \\
\text { flammability limit. } \\
\text { - Tank dome collapse due to overload (3.4.2.3.6): } \\
\text { - This event is deemed beyond extremely unlikely for } \\
\text { the mixer pump test based on analysis of dead load, } \\
\text { live load, jet impingement, and seismic loads. All } \\
\text { components of the support system were found adequate } \\
\text { to support the mixer pumps for both service and } \\
\text { extreme conditions. } \\
\text { - Seismic (3.4.2.3.7): } \\
\text { the pump support and riser conf iguration are } \\
\text { acceptable for the applied design requirements. }\end{array}$ & $\begin{array}{l}\text { LCO } 3.4 .1 \text {, } \\
\text { AWF IOSRS } \\
\text { LCO } 3.2 .2 \\
\text { AWF IOSRS } \\
\text { Tank Farms Standing } \\
\text { Order } 97-01 \\
\text { AC } 5.22 \\
\text { AWF } 10 \text {, } \\
\text { Design Feature }\end{array}$ \\
\hline $\begin{array}{l}\text { Criticality } \\
\text { (Section } 3.4 .2 .4)\end{array}$ & $\begin{array}{l}\text { A criticality Safety Evaluation Report prepared for } \\
\text { Project } W \text { - } 151 \text { identified no scenario associated with the } \\
\text { mixer pump test that could credibly lead to criticality. }\end{array}$ & $\begin{array}{l}\text { AC } 5.12, \\
\text { AWF IOSRS }\end{array}$ \\
\hline
\end{tabular}

$A C=$ Adninistrative Control.

AWF = Aging Waste Facility.

IOSRS = Interim Operational Safety Requirements

$L C O=$ Limiting Condition for Operation. 


\section{ES. 5 ORGANIZATIONS}

Prior to October 1, 1996, Westinghouse Hanford Company and ICF Kaiser Hanford were responsible for design, construction, and testing associated with the mixer pump test. Westinghouse Hanford Company was also responsible for operations, project management, and safety analysis. Since October 1, 1996, Fluor Daniel Hanford, Incorporated has acted as management contractor and is ultimately responsible for contract performance, which includes protecting the public, workers, and environment from anticipated hazards associated with Hanford Site operations, and for being the focal point for interaction with DOE and the stakeholders. Fluor Daniel Northwest has been responsible for design, construction, and testing; Lockheed Martin Hanford Corporation has been responsible for operations; Numatec Hanford Corporation has been responsible for project management; and Duke Engineering and Services Hanford, Inc. has been responsible for the nuclear safety analysis and licensing process.

\section{ES. 6 SAFETY ANALYSIS CONCLUSIONS}

It is concluded that conducting the mixer pump test does not require any additional controls beyond those currentiy existing in the AWF Interim Operational Safety Requirements (IOSR)s (Heubach 1996) and Standing Order 97-01 (Wicks et a1. 1997) to ensure protection of workers and the public. 


\section{HNF-SD-WM-SARR-042 REV 1}

\section{ES. 7 DOCUMENT ORGANIZATION}

This document is organized in the format of DOE-STD-3009-94. Genera] information pertaining to TWRS or the entire Hanford Site and specific information pertaining to the AWF tanks, but not directly relevant to the mixer pump test, are provided via reference to the approved TWRS BIO. 


\subsection{SITE CHARACTERISTICS}

\subsection{INTRODUCTION}

The objective of this chapter is to describe any changes to the site characteristics of the Hanford Site provided in Appendix $C$ of WHC-SD-WM-BI0-001, Rev. 0, Tank Waste Remediation System Basis for Interim Operation (TWRS BIO)(Wagoner 1997) due to the installation of the Project W-151 mixer pumps and performance of the mixer pump test. Tank 241-AZ-101 is located in the Aging Waste Facility (AWF) of the Tank Waste Remediation System (TWRS) in the 200 East Area of the Hanford Site. See Chapter 2.0 for the changes to the facility descriptions provided in Appendix B of the TWRS BIO and for the process descriptions of the mixer pump test.

It is not the intent of this chapter (including its references to the TWRS BIO) to provide all of the information suggested by the guidance of DOE-STD-3009-94. The objective of this chapter is to provide the information necessary to describe the facility s location, identify any hazards due to that location, and identify critical parameters used in Chapter 3.0.

\subsection{REQUIREMENTS}

See Appendix C of the TWRS BIO for the requirements for Hanford Site characterization in support of safety analysis and design. There are no changes to these requirements as a result of the installation of the W-151 mixer pumps or performance of the mixer pump test.

\subsection{SITE DESCRIPTION}

See Appendix C of the TWRS BIO for the Hanford Site description. There are no changes to the site description as a result of the installation of the $W-151$ mixer pumps or performance of the mixer pump test.

\subsection{ENVIRONMENTAL DESCRIPTION}

See Appendix C of the TWRS BIO for a discussion of the meteorology, hydrology, and geology of the Hanford Site. There are no changes to the environmental description as a result of installation of the $W-151$ mixer pumps or performance of the mixer pump test. This data from the TWRS BIO is used to calculate radiological and toxicological impacts to receptors (onsite and offsite) from accident scenarios outlined in Chapter 3.0 .

\subsection{NATURAL PHENOMENA THREATS}

See Appendix C, Section 1.5 of the TWRS BIO for a description of the natural phenomena threats. There are no changes to the natural phenomena threats as a result of installation of the $W-151$ mixer pumps or performance of the mixer pump test. The potential impact of natural phenomena threats as a result of performance of the mixer pump test is evaluated in Chapter 3.0 and in Appendix $3 \mathrm{~A}$. 


\subsection{EXTERNAL MAN-MADE THREATS}

See Appendix C, Section 1.6 of the TWRS BIO for a description of the external man-made threats. There are no changes to the external man-made threats as a result of the installation of the $W-151$ mixer pumps or performance of the mixer pump test.

\subsection{NEARBY FACILITIES}

See Appendix C, Section 1.7 of the TWRS BI0 for a description of nearby facilities. There are no changes to the potential effects on Tank Waste Remediation System (TWRS) facilities from nearby facilities as a result of installation of the W-151 mixer pumps or performance of the mixer pump test. Accidents associated with performance of the mixer pump test with the potential to affect the maximum onsite individual (which may include people at some of the facilities listed in Section 1.7.1 of Appendix C of the TWRS BI0) are discussed in Chapter 3.0.

\subsection{VALIDITY OF EXISTING ENVIRONMENTAL ANALYSES}

Project $W-151$ and the performance of the mixer pump test were evaluated by the U.S. Department of Energy, Richland Operations Office (RL) and found to be within the scope of the existing Environmental Impact Statement (EIS) DOE-EIS-0113, "Disposal of Hanford Defense High-Level, Transuranic, and Tank Waste" (Gerton 1990). The site characteristics data are in agreement with the data contained in the TWRS Environmental Impact Statement (DOE-EIS-0189). 


\subsection{FACILITY DESCRIPTION}

\section{I INTRODUCTION}

The purpose of this chapter is to describe any changes to the description of the Tank Waste Remediation Systems (TWRS) Aging Waste Facility (AWF) provided in Section 2.4.4.1.1 of Appendix B of the Tank Waste Remediation System Basis for Interim Operations (TWRS BI0), WHC-SD-WM-BI0-001 Rev 0, due to the installation of the $W-151$ mixer pumps and performance of the mixer pump test. The mixer pump test is similar in concept to previous mixer pump operations performed in Hanford waste tanks (Wicks 1997). However, the size and power of the mixer pumps used during this test will be considerably larger than those used in the past ( $300 \mathrm{hp} v \mathrm{~s} .75 \mathrm{hp}$ ). This chapter describes the process test to be performed in Tank 241-AZ-101. The facility and process descriptions (both in this chapter and the TWRS BIO) support the assumptions used in Chapter 3.0 .

The scope of this document is limited to the performance of the mixer pump test. Unreviewed Safety Question Determinations (USQDs) TF-96-0018, TF-96-0461, TF-96-0448, and TF-96-0805 verified that the installation of the two mixer pumps, the in-tank camera system, the profile thermocouples, and the Ultrasonic Interface Level Analyzer (URSILLA), respectively, into Tank 241-AZ-101 were within the current TWRS authorization basis, and USQD TF-96-104l verified that checkout testing of the installed equipment was within the current TWRS authorization basis. Safety considerations associated with performance of the mixer pump test are evaluated by this Safety Analysis Report Reference (SARR).

This document augments the current TWRS authorization basis. This document does not evaluate removal of the mixer pumps since no decision had been made regarding pump removal at the time that this SARR was approved. Safety considerations for removal of the pumps will be addressed by separate safety documentation if the decision is made to remove the pumps.

The mixer pump test has been evaluated to cover use of the existing ventilation system (241-A-702) or the ventilation system upgrade provided by Project $W-030$. Analys is of Project $W-030$ is outside of the scope of this document and is addressed in draft HNF-SD-WM-SARR-039. Should the Project W-030 ventilation system upgrade be in service at the time of the mixer pump test, HNF-SD-WM-SARR-039 will have been approved and made available as a referenceable source for additional information on the $W-030$ ventilation system equipment and safety analyses. The hazard and accident analysis within this SARR is limited to the scope and impact of the mixer pump test, and therefore, does not address hazards already addressed within the current authorization basis and not related to or affected by the mixer pump test.

The mixer pump test will use two high-capacity mixer pumps to demonstrate solids mobilization on Hanford waste in Tank 241-AZ-101. The information and experience gained during the test will provide data for comparison with sludge mobilization prediction models; provide data to estimate the number, location and cycle times of the mixer pumps; and provide indication of the effects of mixer pump operation on the AWF Tank systems and components. The slurry produced will be evaluated for future pretreatment processing. This process test does not transfer waste from or to the tank; the waste is mixed and 
confined within the existing system. At the completion of the mixer pump test; Tank Farm Operations will stop the mixer pumps and resume normal tank operations, maintenance and surveillance. The test is equivalent to any maintenance testing of pumping equipment, and provides a gradual operation of the system to determine maximum and minimum effectiveness.

\subsection{REQUIREMENTS}

See Project $W-151$ Functional Design Criteria (FDC) (Nordquist 1997) for identification of design codes, standards, regulations, and the U.S. Department of Energy (DOE) orders relevant to the design and construction of Project $W-151$.

\subsection{FACILITY OVERVIEW}

Project $W-151$ and the mixer pump test do not impact the currently defined mission of the TWRS facilities or the basic processes in use, as defined in Section 2.3.1 of Appendix B of the TWRS BIO. The following discussion is limited to providing information applicable to Project $W-151$ and the mixer pump test. Information provided here consists of any and a7l changes to the Aging Waste Facility (AWF) configuration and process description provided in Appendix B of the TWRS BIO.

The AWF tanks currently contain a mixture of liquid and sludge with both radioactive and hazardous compounds. The current waste inventory for Tank 241-AZ-101 is presented in Appendix B of the TWRS BI0. The current heat generation rate associated with Tank 241-AZ-101, without the mixer pumps, is $70,806 \mathrm{~W}(241,600 \mathrm{Btu} / \mathrm{h})$ (Hodgson 1995). The $300 \mathrm{hp}$ mixer pumps have a thermal input to the waste of $201,000 \mathrm{~W}(687,000 \mathrm{Btu} / \mathrm{h})$ each (Nordquist 1997), resulting in a total heat load for the tank, with both mixer pumps, of $472,806 \mathrm{~W}(1,613,000 \mathrm{Btu} / \mathrm{h})$.

\subsection{FACILITY STRUCTURE}

The following discussion is limited to providing information applicable to Project $W-151$ equipment. Information provided here consists of any and all changes to the AWF equipment description provided in Appendix B, Sections 2.4.3 and 2.4.4 of the TWRS BIO.

Figure 2-1 provides a top-view of the tank and locates the mixer pumps and temperature monitoring equipment within the tank provided by the $W-151$ project. See Appendix B of the TWRS BIO for additional information on AWF tank temperature monitoring equipment.

A brief listing of the characteristics of each mixer pump is provided in Table 2-1. Additional pump information is provided in Nordquist 1997, and WHC 1996a and WHC 1996b. The two mixer pumps are installed in Tank 24l-AZ-101 through existing $1.1 \mathrm{~m}(42-i n$.$) risers in the tank. The design life of the$ individual mixer pump components is five years or 44,000 hours. The design 1 ife of the permanent modifications of Tank 241-AZ-101 and non-replacement ancillary and support equipment is consistent with the remainder of the 50year design 1 ife of the 241-AZ tank farm, which was completed in 1976 . Replaceable equipment and components may have a shorter design 1 ife, but generally not less than five years. 
Analys is of pump-to-pump interaction has been completed in the vendor supplied information (Nordquist 1996). Pump effects, which included the effects of pump operational and environmental conditions, were found to be much greater on the smaller equipment already existing in the tank than for pump-to-pump interaction.

To determine the effects of pump operation on in-tank equipment, structural analyses were performed. Waters and Heimberger 1993 states that for the small number of cycles involved, the stress levels on in-tank components (including the Air Lift Circulators (ALCS)) are well below the allowable limits. Additional analysis (Julyk 1997) states there is a potential for some damage to the thermocouples attached to the ALCs (not safety related equipment) if there are agglomerations of hardened sludge adhering to the thermocouples. Tank 24l-AZ-101 has twenty-two ALCs used to establish convective currents within the tank's supernatant region, and to some degree, mobilize the sludge which settles to the bottom of the tank. During the mixer pump test, the ALCs will be left off as much as possible to determine the effectiveness of the mixer pumps. For the steam coil installed in Tank 241-AZ-101, an analys is was performed to determine the allowable number of stress cycles that could be withstood to support mixer pump operation at the steam coil's current location (Crass 1996). The number of stress cycles are determined by multiplying the mixer pump's rotational speed (the speed at which the entire mixer pump unit rotates about its vertical axis in the oscillating mode) by the time of the mixer pump operation. The rotational speed of the mixer pump assembly, including the casing, is relatively slow as compared to the pump impeller speeds $(0.05$ to $0.2 \mathrm{rpm}$, as compared to $1,200 \mathrm{rpm})$. Initially, it was thought that the steam coil would have to be raised out of the path of pump discharge. However, at the current location of the steam coil (approximately $53 \mathrm{~cm}$ (21-in.) from the tank bottom), the allowable stress cycles are 200,000 . These 200,000 stress cycles at a maximum rotational speed of $0.1 \mathrm{rpm}$ translates to 16,600 hours. At a maximum rotational speed of $0.2 \mathrm{rpm}$ the pumps can safely operate for 160,000 cycles or 6,650 hours (Crass 1996).

In addition, the potential for pump operation to result in erosion of the tank 1iner is addressed in Section 3.4.2.3.4. Erosion of in-tank equipment is considered to be bounded by that of the tank liner analysis. Erosion of in-tank equipment will not affect equipment operability and therefore is considered acceptable for the duration of the test. 
Figure 2-1 Top-view of Tank 241-AZ-101

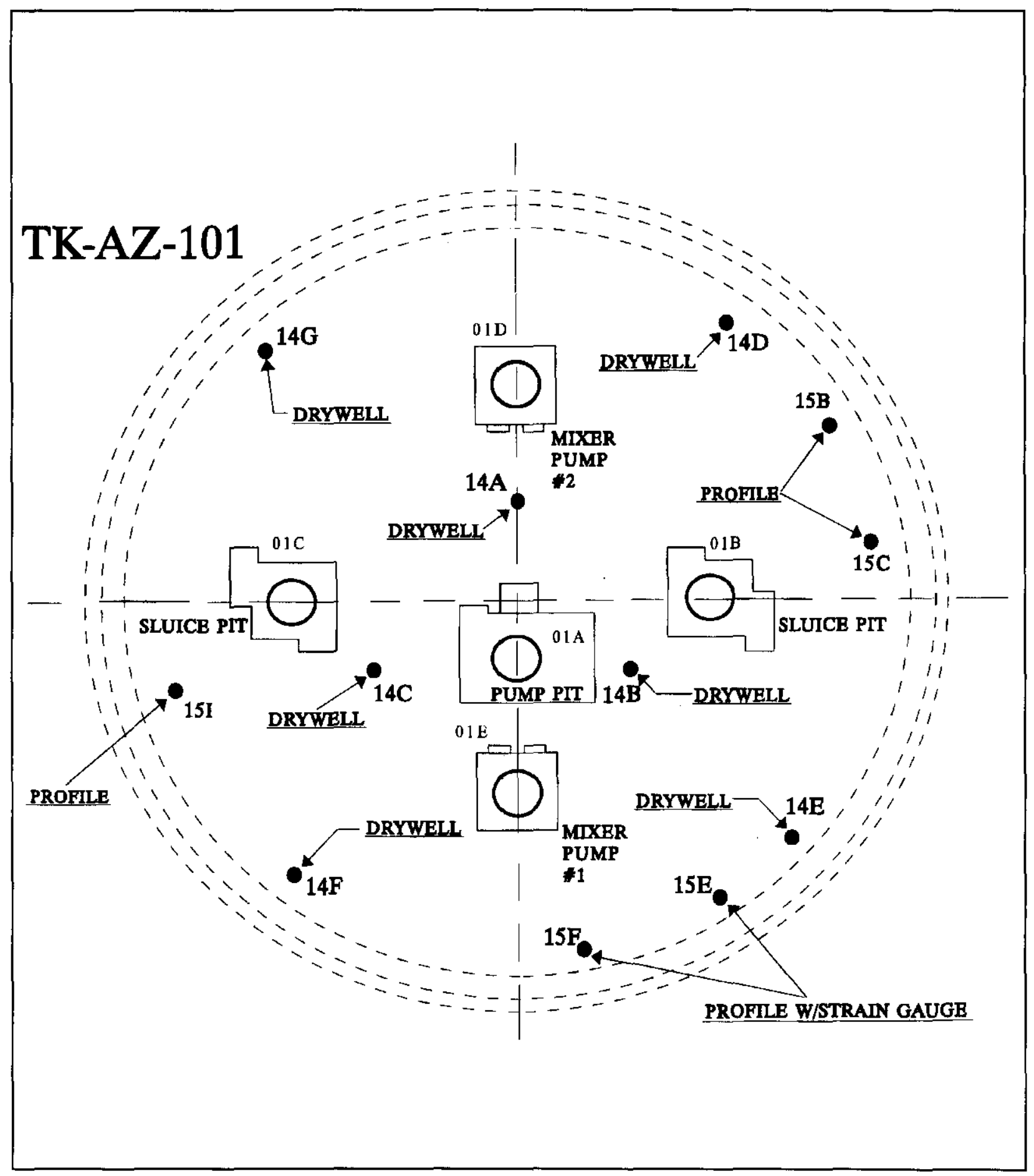

Note: "Profile" refers to the profile thermocouples present in the tank. 
Table 2-1 Project $W$-151 Mixer Pump Characteristics

\begin{tabular}{|c|c|}
\hline Pump type & Vertical line shaft drive mixer pump \\
\hline Motor type & $\begin{array}{l}300 \mathrm{hp}, 1,200 \mathrm{rpm}, 480 \mathrm{~V} / 3 \mathrm{Phase} / 60 \mathrm{HZ} \\
\text { weather-protected enclosure }\end{array}$ \\
\hline Total pump weight & $\begin{array}{l}12,247 \mathrm{~kg}(27,000 \mathrm{~Tb}) \text { (water column } \\
\text { filled) }\end{array}$ \\
\hline Pump dimensions & $\begin{array}{l}17 \mathrm{~m} \text { by } 41 \mathrm{~cm}(56 \mathrm{ft} \text { by } 16 \mathrm{in}) \text { (from } \\
\text { support connection to bottom of the } \\
\text { screen) }\end{array}$ \\
\hline Number of jet nozzles & (2) $180^{\circ}$ opposed \\
\hline Diameter of each nozzle & $15 \mathrm{~cm}(6 \mathrm{in})$ \\
\hline Max Flow rate of each nozzle & $19,680 \mathrm{~L} / \mathrm{mn} \quad(5,200 \mathrm{gpm})$ \\
\hline (Velocity) $x$ (nozzle diameter) & $2.7 \mathrm{~m}^{2} / \mathrm{s}\left(29.4 \mathrm{ft}^{2} / \mathrm{s}\right)$ \\
\hline Jet flow direction & Horizontal \\
\hline $\begin{array}{l}\text { Nozzle centerline distribution above } \\
\text { floor }\end{array}$ & $43 \mathrm{~cm}$ (17 in.) \\
\hline Pump rotation & $\begin{array}{l}\text { Fixed, or } 180^{\circ} \text { oscillating at } 0.05 \text { to } \\
0.2 \mathrm{rpm}\end{array}$ \\
\hline
\end{tabular}

Mixer pump system components and assemblies located at or within the double-shell tank (DST) are designed to withstand the anticipated radiation environment as specified in Nordquist 1997. In addition, mixer pump system components and assemblies that will contact the waste are compatible with the waste fluid properties present in the tank as specified in Nordquist 1997. Those in-tank parts of the mixer pumps and other in-tank equipment submerged in the liquid may potentially be exposed to waste at temperatures from $40^{\circ} \mathrm{C}$ to $100{ }^{\circ} \mathrm{C}\left(104\right.$ to $\left.212{ }^{\circ} \mathrm{F}\right)$ during normal operations.

\subsection{PROCESS DESCRIPTION}

Other than the installation of the mixer pumps, Project $W-151$ and the mixer pump test do not impact the facility's currently defined mission or the basic processes in use. This section describes the mixer pump test.

\subsubsection{Mixer Pump Testing}

Tank 24l-AZ-10l has been selected for the first full-scale demonstration testing of a mixer pump system. The tank currently holds over $3.63 \mathrm{ML}$ (960 Kgal) of neutralized current acid waste, including approximately $31.8 \mathrm{~cm}$ (12.7 in) of settling solids (sludge) at the bottom of the tank (Hodgson 1995). 
The mixer pump test goals are to provide actual in-tank operations of mixer pumps, effectively mobilize solids within the supernatant, provide empirical data for determination of the mixer pump effective cleaning radius (distance out from pump discharge at which the effectiveness of the pump in mobilizing tank solids significantly decreases), and provide further justification for use of mixer pumps on other DSTs. The mixer pump test may consist of three pump configuration phases, including:

- Single Pump - Fixed Mode

- Single Pump - Oscillating Mode

- Two Pumps - Oscillating Mode

In addition to the pumping or mixing modes, two other tank conditions during the mixer pump test are considered in this SARR and discussed as "modes":

- Pump Shutdown - Initial Waste Settling Phase

- Long-Term Re-compaction of solids

The mixer pumps are designed to operate in a fixed position (fixed mode during the single pump portion of the test) or to continuousiy oscillate from $\pm 180^{\circ}$ to $0^{\circ}$ (oscillating mode). In the oscillating mode, the effective rotation rate of the jet nozzles will be operated from $0.05 \mathrm{rpm}$ to $0.2 \mathrm{rpm}$ during the mixer pump test. Testing will also initially include slowly increasing from $700 \mathrm{rpm}$ to $1,200 \mathrm{rpm}$ instead of increasing directly to full power in order to evaluate the accuracy of modeling conclusions. It is expected that a reasonable duration of mixing to achieve maximum mobilization is from 10 to 20 days (Symons and Staehr 1996).

\subsection{CONFINEMENT SYSTEMS}

The mixer pump test was analyzed to cover the use of either the ventilation system upgrade provided by Project $W-030$ or the 241-A-702 ventilation system. The current ventilation system for Tank 241-AZ-101 is the 241-A-702 AWF ventilation system described in Appendix B, Section 2.4.3.7.1 of the TWRS BIO. However, Project $W-030$ will provide a ventilation system upgrade for the AWF (which includes Tank 241-AZ-101) as described in HNF-SD-WM-SARR-039 (Draft). Since there is uncertainty about which of these ventilation systems will be operational during the mixer pump test, the safety analyses provided in this document evaluate both ventilation systems. Either ventilation system can remove the calculated heat load for bulk waste temperatures (Sathyanarayana 1994, Rice 1992a, Rice 1992b, Collins 1992) for mixer pump operation (See Section 3.4.2.2 for additional information).

\subsubsection{1-AY and 241-AZ (Aging Waste Facility) Tank Farm Ventilation System - Project $W-030$}

See HNF-SD-WM-SARR-039 (Draft) for a description of the Project $W-030$ ventilation system. There are no changes to this ventilation system as a result of installation of the $W-151$ mixer pumps or performance of the mixer pump test. 
HNF-SD-WM-SARR-042 REV 1

\subsubsection{1-AY and 241-AZ (Aging Waste Facility) Tank Farm Ventilation System - 241-A-702}

See Appendix B, Section 2.4.3.7.1 of the TWRS BIO for a description of the 241-A-702 AWF ventilation system. There are no changes to this ventilation system as a result of the installation of the $W-151$ mixer pumps or operation of the mixer pump test.

\subsubsection{Annulus Exhaust Flow Description}

See Appendix B, Section 2.4.3.7.1 of the TWRS BI0 for a description of the AWF annulus ventilation system. There are no changes to this ventilation system as a result of installation of the $W-151$ mixer pumps or operation of the mixer pump test. Currently, the annulus exhauster is non-operational, and the conservative assumption has been made for the thermal analyses of Chapter 3.0 that it will remain unavailable during the mixer pump test. Should it be returned to service prior to the mixer pump test, additional tank cooling would be provided by the system, and all tank thermal margins to operational and safety limits would be increased.

\subsection{SAFETY SUPPORT SYSTEMS}

Existing equipment in Tank 241-AZ-101 monitors and records selected parameters during the mixer pump test. The following describes (1) the appropriate section of the TWRS BIO where descriptions of the existing equipment may be located, and (2) the Tank 241-AZ-101 mixer pump system equipment.

\subsubsection{Existing Equipment}

See Section 2.4.11 of Appendix B of the TWRS BIO for a description of the existing equipment within Tank 241-AZ-101 which will be used to monitor and record parameters during the mixer pump test. Any changes or additional cautions involved with using this equipment during the mixer pump test are discussed below.

\subsubsection{Liquid Level Measurement System}

During the mixer pump test, liquid level measurement will be taken either manually using a tape or by using an $\operatorname{ENRAF}^{(T M)}$ gauge to comply with Limiting Conditions for Operation (LCO) 3.1.1, "Primary Tank Waste Level Monitoring Systems" and LCO 3.4.4, "Air Lift Circulators (ALC)"(Heubach 1996). Caution is to be taken during mixer pump operation because the ENRAF $^{(T M)}$ liquid level detector could be damaged when lowered into the tank during mixer pump operation. The ENRAF ${ }^{(T M)}$ liquid level is a micro-processor-controlled tank gauge which accurately measures the liquid level. During testing, liquid level measurement with an $\operatorname{ENRAF}^{(T M)}$ gauge will be taken when the mixer pump(s) is off, or by other means (e.g., manually) in order to comply with the action statements of LCO 3.1.1 to measure tank waste level at least once every 36 hours. For the mixer pump test, level data will be measured and manually logged. 


\subsubsection{Temperature Monitoring}

Temperature monitoring, per LCO 3.2.1, "Primary Tank Waste Temperature Monitoring Systems", in the waste tanks is required to maintain tank operating conditions. For the mixer pump test, as described in the mixer pump test plan (Symons and Staehr 1996), the temperature data, collected and analyzed, provides information about the waste temperature within the tank before, during and after the mixer pump test. This system provides one method of identifying any potential localized accumulation of solids, which would develop into thermal "hot spots," and, if allowed to accumulate to a high enough Tevel (see Section 2.4.4.1.1 and Figure 2-24 of Appendix B of the TWRS BIO for details of the ALCS), could potentially block the functionality of the ALC at that location until the solids were re-distributed. Other process equipment is in place to also monitor solids distribution, as described in Section 2.7.2, because of a potential for unavailability of the ALC thermocouples due to the potential for damage from mixer pump jet forces (JuTyk 1997). See Chapter 3 for a description of the effects of solids accumulations.

In accordance with Symons and Staehr 1996, the tank bottom thermocouples, profile thermocouples, airlift circulator thermocouples, and sludge thermocouples may be used to monitor the growth of the effective cleaning radius area when the mixer pumps are operating. The thermocouple data will be monitored before, during and after pump operation. See Section 2.4.11.4.2 of Appendix B of the TWRS BI0 for a description of AWF Tank temperature monitoring equipment and locations.

\subsubsection{Hydrogen Monitoring}

Monitoring requirements for flammable gas accumulation in tank headspace are specified in the TWRS Standing Order 97-01 (Wicks et a1. 1997). A Standard Hydrogen Monitoring System (SHMS) cabinet has been installed on Tank 241-AZ-101, which will be used to take hydrogen concentration readings, as required, during the testing. Data from the SHMS will be recorded manual7y, as specified in Symons and Staehr 1996.

\subsubsection{Tank Pressure Monitoring}

The pressure/vacuum within the 241-AZ-101 primary tank (i.e., vapor space) is continuously monitored as discussed in Section 2.4.11.7 of Appendix $B$ of the TWRS BIO. 


\subsubsection{Process Air System}

The compressed air system provides process air to operate air-7ift circulators (ALC). Instrument air is generated to operate critical valves on the 702-A ventilation system. The compressed air system includes the following items:

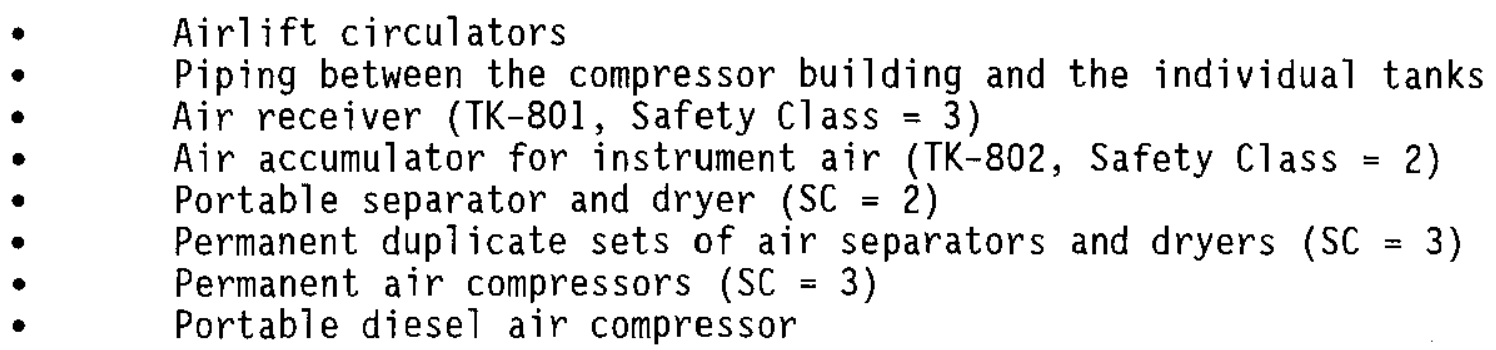

\subsection{Airlift Circulators}

There are 22 airlift circulators (ALC) in each of the 241-AY and 241-AZ Tanks. See section 2.4.4.1.1 of the TWRS BIO for a brief general description of the ALCs. Additional details of the ALC system are provided below.

The ALCs are relatively simple devices consisting of two basic components: a vertical lift riser pipe $76 \mathrm{~cm}(30-$ in.) in diameter, and a foot piece (air nozzle) located within and near the lower end. A $15 \mathrm{~cm}$ (6-in.) pipe suspends the lift riser from the tank dome and concentrically extends to a $3.8 \mathrm{~cm}$ (1.5-in.) inner diameter nipple. A $2.5 \mathrm{~cm}$ (1-in.) pipe, which supplies the motive air, is a removable insert that extends within the $15 \mathrm{~cm}$ $(6-i n)$ pipe to $5 \mathrm{~cm}(2-i n$.$) below the swaged nipple. This is the one$ component which can be replaced in the event of a pluggage. The entire unit is of mild steel construction. The lower ends of all the 1 ift risers are 76 $\mathrm{cm}(30-i n)$ above the tank bottom.

Air is injected into the lift riser at the foot of the air lift, draws in liquid from the bottom of the tank, and pushes the fluids up the circulator and out the top. The large liquid flow rates generated with the circulators will create turbulent flow in the tank contents. Liquids flowing along the bottom of the tank and up the draft tubes will carry solid particles out the top of the circulator as they are discharged in the upper region of the tank. The vertical fluid motion decreases the temperature differential between the top and bottom of the tank by transporting warm liquids and solids from the bottom of the tank to the cooler regions at the top. A computer analysis of the adequacy of the circulator capabilities for suspending and mixing was made by Pacific Northwest Laboratories (Fineman 1984).

\subsection{Air Compressor Building}

Process and Instrument Air is supplied to the 241-AY and 241-AZ Tank Farms from the 241-A-701 Compressor Building. The 241-A-701 building compressed air system was upgraded from late 1993 to 1995. It contains two Ingersol1-Rand glycol/water cooled electric air compressors. Each compressor is powered by a $125 \mathrm{Hp}$ electric motor and will supply about $2.1 \times 10^{-1} \mathrm{~m}^{3} / \mathrm{s}$ $(440 \mathrm{scfm})$ at $1.0 \mathrm{MPa}$ (150 1bf/in ${ }^{2}$ gauge). Normally one compressor will be operated, and the other acts as a backup. They will be rotated to ensure that 
they have about the same amount of use and that they remain operable. A dedicated portable diesel driven air compressor is available at the Compressor Building as backup. A portable safety significant $(\mathrm{SC}=2)$ air separator and air dryer system is available (in use) outside of 241-A-701 building. Minteer and Carpenter 1993 contain a discussion of the reduction of the compressor's safety class from SC 2 to 3 . See Chapter 4 for a further discussion of the correlation between the previous numbered safety class system used at the Hanford Site, and the DOE Standard 3009-94 terms "safety class" and "safety significant".

Air from the compressors passes through a cooler and separator to remove moisture and droplets. The air goes to an air receiver tank located behind 241-A-701. For instrument air, the air is routed through a separator and air dryer to further remove water droplets, particulates, and vapors. For process air, these dryers and filters are bypassed.

Process air is reduced to $0.3 \mathrm{MPa}\left(41 \mathrm{lbf} / \mathrm{in}^{2}\right.$ gauge) through a pressure reducing valve and then one $7.6 \mathrm{~cm}(3-i n$.$) line is routed to the 241-AX, AY,$ and $A Z$ tank farms. Process air is piped to the 801 buildings in the 241-AZ and 24l-AY Tank Farms. Another pipeline leaves the Compressor Building to the 241-A tank farm.

Instrument air from 241-A-701 is routed to a safety significant ( $S C=2)$ air accumulator, reduced in pressure to $0.2 \mathrm{MPa}\left(35 \mathrm{lbf} / \mathrm{in}^{2}\right.$ gauge) and then to the 241-A-702 ventilation building. Instrument air is routed to 241-AX, $A Y$ and $A Z$ farms through a $2.5 \mathrm{~cm}$ (1-in.) 1 ine.

Rotameters located in the 241-AY-801 and 241-AZ-801A Instrument Buildings are used to indicate the air flow rate to the individual circulators. An adjoining raw water header (and associated valving) are provided at this location for water flushing of the ALC lines. Connections are available for the emergency diesel air compressor at the air headers in the 241-AY-801 and 241-AZ-801A buildings, if required.

\subsubsection{Tank 241-AZ-101 Mixer Pump System Equipment}

The process control system for the mixer pump test consists of:

- Pump column water pressure normal and low indicators

- Pump column supply filter normal and high indicators

- Motor bearing high temperature alarm, and motor bearing maximum temperature alarm and interlock

- Motor winding maximum temperature alarm and interlock

- High pump current alarm, and maximum pump current alarm and interlock

In addition, the mixer pump test will use three existing safety control systems in support of process control. These are:

- Tank vapor pressure alarm and tank low vacuum alarms (existing) 
- Maximum tank temperature alarm (existing)

- Tank liquid level minimum, absolute minimum, and maximum alarms (existing)

The mixer pump motors and connections are above tank farm grade (i.e., in an area without direct connection or exposure to tank headspace) and contain no accumulation areas for flammable gas buildup around the motors. To provide cooling, the mixer pump line shaft bearings are enclosed in a water column, which also prevents sparking. In addition, the volute and impeller are 304 stainless steel and the process bearing is submerged in the waste, which prevent sparks (Crass 1993).

As noted in Section 2.5, the mixer pumps are being started slowly as part of the mixer pump process test. This will serve as a preventive measure against a sudden gas release, although gas pockets within the sludge are not expected (Hodgson 1996). In addition, the mixer pump test procedure (Ross 1997) contains requirements to comply with Wicks et al. 1997. Prior to startup of a mixer pump or change in the mixing test mode, the tank's exhaust or headspace must be sampled for flammable gas to verify it to be $<25 \%$ of the lower flammability limit (LFL).

The waste profile thermocouples and transfer pump are carbon steel and are installed in carbon steel risers. Normally, there is no movement of any of these pieces of equipment. However, due to mixer pump operation, they may sway (Waters and Heimberger 1993). The flammable gas hazard has been evaluated in Chapter 3.0, Section 3.4.2.3.1.

A closed-circuit television system, with videocassette recorder capabilities, will be installed in the tank headspace and will be monitored for information purposes to determine whether any in-tank equipment has been damaged or is being damaged by the mixer pumps. The use of the camera has been determined to be a prudent measure for defense-in-depth. (Analyses have shown safety equipment to be within allowable stress margins, though Julyk 1997 recommended that the ALCS be monitored by camera to avoid flow-induced resonant vibration coupling for more than a duration of one hour. Julyk 1997 also states that resonant coupling is not likely in the tank because of the non-uniform nature of the flow patterns.) It is intended that the closedcircuit television be operated during the entire mixer pump test. But, if the functionality of the camera is lost during the mixer pump test, the test may be continued, once the reason for the camera failure has been determined.

The surveillance camera is housed in a stainless steel, purged enclosure. This enclosure is designed, in accordance with the requirements of Wicks et a1. 1997 and approved by the Flammable Gas Equipment Advisory Board (Smet 1997), to provide a continuously isolated (purged and pressurized) environment for a potentially sparking camera system (either the electronics of the camera itself or the direct current pan and tilt motor for the unit) from a potentially flammable gas environment. Upon loss of purge, the in-tank camera equipment will shut down automatically, de-energizing the system and stopping all sparking potential. 
Two gamma profilers may be installed in existing drywell locations to help determine the mixer pump effective cleaning radius during the test and the degree of solids distribution within the supernatant. These pieces of equipment are manually operated (i.e., raised and lowered in the drywell manually) and the readings may be taken during mixer pump operation. In compliance with the requirements of Wicks et al. 1997, the drywells are checked for flammable gas accumulation to ensure integrity of the well on a monthly basis. The housing of the profilers are made from stainless steel and all electrical connections are above tank farm grade (i.e., in an area without direct connection or exposure to tank headspace).

Strain gauges installed on the profile thermocouple trees will monitor the impingement jet force from the mixer pump. The strain gauges are used while the mixer pumps are in operation. The collected data will be measured and stored in a personal computer data spreadsheet program, maintained by the operators. The strain gauges on the profile thermocouple trees are nonsparking during normal operation and all electrical connections are above tank farm grade (i.e., in an area without direct connection or exposure to tank headspace). The strain gauges are also isolated from the tank's vapor space with a welded cover.

Vibration of the mixer pump assembly will be measured by the use of a vibration switch mounted to the pump motor, which is preset to provide indication, should vibrations exceed vibration set-points.

The ultrasonic interface level analyzer (URSILLA) (Royce Model 2511) system consists of three individual units that use an ultrasonic ranging technique to measure the depth of the sludge interfaces within the supernatant. The URSILLA will be operated continuously, and collected data measured and stored in a personal computer data spreadsheet program, maintained by the test engineers. The URSILLA's sensors will be located approximately $4.5 \mathrm{~m}$ (15 ft) off the tank bottom, and will be housed and sealed from the tank's atmosphere and waste in $5.1-\mathrm{cm}$ dia (2-in) stainless steel housings and a11 electrical connections are above tank farm grade (i.e., in an area without direct connection or exposure to tank headspace). The three units provide a high degree of redundancy for process data. The mixer pump test plan only requires two of the three units to be operational during the mixer pump test.

Instrumentation monitors the following:

- Mixer pump motor and bearing temperature

- Pressure readings on pump bearing/seal lubrication water pressure

- Electrical parameters including current, voltage, and frequency

- Rotary position to determine pump orientation

- Bending of selected in-tank equipment through the use of strain gauges (See Figure 2-1). 


\subsection{UTILITY DISTRIBUTION SYSTEMS}

Utility distribution systems impacted by Project $W-151$ include the following:

- Water Supply Systems and

- Electrical Power Distribution System.

\subsubsection{Water Supply Systems}

All water for the 200 East Area is supplied from the Hanford Site export water system. Export water is defined as water that is pumped from the Hanford Site reservoir to reservoirs located in the 200 East and West areas. Water is distributed throughout the area by two separate systems, the raw water system and the sanitary water system. Raw water is untreated, and unchlorinated, and is used principally for cooling, flushing, and dilution systems. Sanitary water is treated (filtered, purified, etc.) and used for drinking and sanitary facilities, process, and fire protection.

For Project $W-151$, raw water is provided for mixer pump mechanical seals and bearings. Flushing of the mixer pump for decontamination during potential failed equipment removal and replacement would be provided by tanker-supplied hot water from the power house. Heat trace of the water piping from the tanker connection to the mixer pump is provided.

\subsubsection{Electric Power Systems}

An electrical substation and pump control facility was installed for Project $W-151$. The substation replaced the previous transformer (C8-S27) and, in addition to the existing C8-S27 loads, has the capacity to supply power for the two mixer pumps and associated equipment.

\subsection{AUXILIARY SYSTEMS AND SUPPORT FACILITIES}

No systems or facilities other than those described in the previous sections were identified as requiring descriptions in this document. 
HNF-SD-WM-SARR-042 REV 1

This page intentionaliy left blank. 
HNF-SD-WM-SARR-042 REV 1

\subsection{HAZARD AND ACCIDENT ANALYSIS}

\subsection{INTRODUCTION}

This chapter identifies and evaluates the hazards associated with the mixer pump test in Tank 241-AZ-101. In addition, it evaluates the consequences of potential accidents that could lead to a release of radioactive and hazardous materials. Potential consequences to the offsite public and onsite individuals are considered, as are the corresponding preventive and mitigative features. This chapter is limited to the scope and impact of the Tank 241-AZ-101 mixer pump test and therefore does not address all of the hazards analyzed and presented in the Tank Waste Remediation System (TWRS) Basis for Interim Operation (BI0), WHC-SD-WM-BI0-001, Rev. 0 (Wagoner 1997), or the current TWRS authorization basis (i.e., Interim Safety Basis, Interim Operational Safety Requirements, and Standing Orders).

\subsection{REQUIREMENTS}

The standards and U.S. Department of Energy (DOE) Orders that are required for establishing the safety basis of the mixer pump test are 1 isted below, and are consistent with those listed in Chapter 5.0 of the TWRS BIO. Only portions of these documents are relevant to this safety document; namely, those requirements pertinent to safety analysis.

- DOE 5480.22, Technical Safety Requirements (1992)

- DOE 5480.23, Nuclear Safety Analysis Reports, Change 1, (1994)

- DOE 6430.1A, General Design Criteria (1989) ${ }^{1}$

- DOE Standard 1027-92, Hazard Categorization and Accident Analysis Techniques for Compliance with DOE Order 5480.23, Nuclear Safety Analysis Reports

- DOE Standard 3009-94, Preparation Guide for U.S. Department of Energy Nonreactor Nuclear Facility Safety Analysis Reports

- DOE Standard 3011-94, Guidance for Preparation of DOE-5480.22 (TSR) and DOE-5480.23 (SAR) Implementation Plans.

\footnotetext{
${ }^{1}$ Non-safety related sections of DOE $6430.1 \mathrm{~A}$ will be phased out/canceled upon meeting the implementation conditions of DOE 0430.1 . The portions of DOE $6430.1 \mathrm{~A}$ related to nuclear safety for non-reactor nuclear facilities are canceled by DOE 0420.1 . As of this writing, the new orders have not been transmitted for compliance and therefore, compliance with DOE 6430.1A is required.
} 
HNF-SD-WM-SARR-042 REV 1

\subsection{HAZARDS ANALYSIS}

\subsubsection{Methodology}

The methodology used to perform this safety analys is is described in Section 5.2.1 of the TWRS BIO. The purpose of this safety analys is is to analyze the specific hazards related to the operation of two $300 \mathrm{hp} \mathrm{mixer}$ pumps in tank 241-AZ-101 and also to assess the changes (i.e., assumptions and conclusions) in the current analysis due to the performance of the test.

The hazards analyzed were those identified in the Hazards and Operability (HAZOP) effort presented in Appendix $3 \mathrm{~A}$ enhanced by subsequent evaluation and comparison with hazards analyses performed for the TWRS BIO and Tanks 241-SY101 and 241-AP-102 mixer pump additions (see Section 3.3.2.4). Sabotage and terrorism are not included. Single and multiple failures (equipment and human errors) are considered as well as common-cause failures.

\subsubsection{Hazard Identification}

The hazard identification procedure used is consistent with that described in Section 5.2.1 of the TWRS BIO.

\subsubsection{Hazard Evaluation}

The technique chosen for the mixer pump test hazards evaluation was the HAZOP study which is the method used in the TWRS BIO.

\subsubsection{Worker Health and Safety Requirements}

This safety analysis addresses the risks to hypothetical onsite individuals at $100 \mathrm{~m}(330 \mathrm{ft})$ and to the public at the Site boundary, and provides for safety equipment and administrative controls to reduce such risks to within risk evaluation guidelines (see Tables 5.3-2 and 5.3-3 of the TWRS BI0). Included are the risks from radioactive materials, toxic gases, and toxic chemicals. The risk evaluation guidelines for the workers and the public are those defined in Tables 5.3-2 and 5.3-3 of the TWRS BIO (see Tables 3-2 and 3-3). The onsite receptor is assumed to be $100 \mathrm{~m}(330 \mathrm{ft}$ ) from the source of releases. This safety analysis does not specify any new controls necessary to protect workers who are located closer than $100 \mathrm{~m}(330 \mathrm{ft})$ to the activity. The current controls that protect workers within $100 \mathrm{~m}(330 \mathrm{ft})$ are defined in the Hanford Site Radiological Control Manual (HSRCM-1 1995) and the Tank Farm Health and Safety Plan (HASP) (Hewitt 1996).

There is a potential for worker exposure to high concentrations of toxic gases during tank intrusive work around open tank risers or from emissions from the ventilation exhauster, including ammonia, nitrous oxide, and various organic species. Concentrations of these gases in the tank vapor space during the mixer pump operation work may be in excess of 0ccupational Safety and Health Administration (OSHA)-allowed values. Because the tank vapor space will be exhausted to the ambient air above the tank, a pathway for worker exposure is recognized to exist. Assessment of the hazards from these materials and protection of the workers is provided by the HASP. Significant elements of this plan include monitoring of the work area for organic vapors, ammonia, and other chemical species whenever there is a potential for elevated 
employee exposure levels. In addition, personnel monitoring is performed on those tasks which are judged to have the highest potential for exposure.

The Tank Farms are considered to be a Resource Conservation and Recovery Act (RCRA) Treatment, Storage and Disposal (TSD) facility, and all work in Tank Farms must comply with the HASP. The TWRS Industrial Hygiene staff has responsibility for implementation of the HASP, including monitoring and personnel sampling. Trained industrial hygiene technicians perform monitoring during each task. If any tank vapor levels are detected that present a possibility of employee over-exposure, the industrial hygiene technicians will take appropriate actions, including the use of personal protective equipment or suspending the activity to ensure that no employee over-exposures occur.

\subsubsection{Hazard Analysis Results}

The following section presents and evaluates the results of the HAZOP for the mixer pump test.

\subsubsection{Hazard Identification}

The results of the HAZOP are a number of postulated abnormal events that are ranked with respect to severity and frequency of occurrence. The Event Severity Index and Event Frequency Index are provided in Tables $3 A-2$ and $3 A-3$, respectively, of Appendix $3 A$.

The complete product of the HAZOP study is presented as a series of tables (Appendix 3A) showing the results of the study.

\subsubsection{Hazard Classification}

The hazard category, as defined in DOE-STD-1027-92 for Tank 241-AZ-101, which is a Double-Shel1 Aging Waste Tank, has been determined to be Category 2 (see Table 5.1-1 in the TWRS BIO). Since the mixer pump test does not segment the facility, change the type or form of waste being stored within the tank, and does not change its location (other than mobilizing the waste within the tank), the hazard classification remains Category 2.

\subsubsection{Hazard Evaluation}

Using the HAZOP evaluation techniques, a Hazard Analysis Summary table (Appendix 3B) was constructed. Hazard Analysis Summary tables have been used to compile the results of the hazard identification and evaluation process for this test. Each column in the hazard tables is described below.

Event Number. Sequential identification for the hazard or accident evaluated.

Event Category. Event category descriptor.

Postulated Event Description. Details on how the hazard or accident can occur.

Significant Causes or Energy Sources. Hazard or accident initiators. 
Receptor. Identifies the affected party (facility worker, onsite worker, public).

Credited Prevention. Engineered or administrative features that would prevent or reduce the probability of the hazard/accident from occurring.

Event Frequency. The qualitative or semi-quantitative assessment of the frequency of occurrence of the hazard/accident with and without preventive features.

Credited mitigation. Engineered or administrative features that would mitigate or reduce the consequences of the hazard/accident.

Consequences. The qualitative or semi-quantitative assessment of the consequences of the hazard/accident with and without mitigative features.

Risk Bin Number. Risk number based on the frequency, the consequences, and the receptor.

Defense-in-Depth Controls. Preventive and mitigative features not credited in the accident analyses.

HAZOP study estimates were made for the likelihood of occurrence (frequency) for each accident shown in the HAZOP study tables. There are four frequency categories. Also shown are four severity categories. These categories were used along with common release mechanisms to bin accidents with common attributes (i.e., accidents that would benefit from the same control and protection strategy). Bin numbers are shown on the HAZOP study tables.

An accident scenario was developed which bounds all common attribute accidents assigned to a bin. Only those accidents with a severity category of S3 and S2 were selected for further accident analysis (See Section 5.2.1.3 "Accident Selection" in the TWRS BIO). The accidents appearing in these categories for further analysis were grouped according to release mechanisms that could result in dispersal of contaminants to an occupied area of the facility, and/or to the onsite and/or offsite receptor. Four bins were identified and therefore, four bounding (candidate) accident scenarios were developed. The bounding candidate accidents are identified in the following section.

\subsubsection{Accident Selection}

The HAZOP study detailed in Appendix $3 A$ resulted in the identification of six postulated events. These events and their related causes and conditions are identified in Appendix 3B. These six postulated events are: (1) a ventilation system High Efficiency Particulate Air (HEPA) filter failure, (2) backflow through open tank risers, (3) leakage via failed vent ducting, (4) a breach of the tank due to internal or external mechanisms, (5) a nuclear criticality induced by mixer pump operations, and (6) a seismic event. 
The next step in the accident selection process involved an evaluation of the specific causes and conditions associated with the postulated events. Using the results of the HAZOP as a starting point, and evaluating the events identified with the analyses of the BIO and other similar analyses performed in support of the mixer pump additions to Tanks 241-SY-101 and 24l-AP-102, some corrections were necessary (particularly regarding inconsistencies in the consequence severity categories identified for the various events). The HAZOP and Hazards Evaluation Tables are included for historical reference. This evaluation identified causes and conditions related and not related to the mixer pump test. Postulated events that involve causes and conditions not related to the mixer pump test are not analyzed. In addition, postulated events bounded by similar accidents are not analyzed. For example, leakage via failed vent ducting is not analyzed since the causes of this accident are not related to the mixer pump test and the accident is bounded by the HEPA filter failure.

This evaluation resulted in the identification of four design basis accidents requiring further analysis: (1) un-filtered release of radionuclides and toxic aerosols from the tank, (2) tank bump, (3) breach of containment, and (4) over-pressurization caused by criticality. The unfiltered release includes an evaluation of HEPA filter failure and reverse flow through the tank.

The tank bump accident scenario is considered separately from the unfiltered release. The breach of containment accident scenario includes many causes and conditions, with the most significant being flammable gas deflagration.

Table 3-1 provides the four design basis accidents, causes and conditions of the accident scenarios, and mapping of the postulated events to the accident analysis in Section 3.4. 
Table 3-1 Accident Selection and Mapping to Analys is

\begin{tabular}{|c|c|c|}
\hline Accident & $\begin{array}{c}\text { Cause or condition due to mixer pump } \\
\text { operation }\end{array}$ & Map to accident analysis \\
\hline \multirow{8}{*}{$\begin{array}{l}\text { 1. Unfiltered release } \\
\text { of radionucl ides and } \\
\text { toxic aerosols from }\end{array}$} & \multicolumn{2}{|l|}{ HEPA filter failure due to: } \\
\hline & $\begin{array}{l}\text { Aerosol generation from chemical } \\
\text { reaction }\end{array}$ & $\begin{array}{l}\text { Waste is not to be added by or during this process test. Therefore, this scenario is } \\
\text { not relevant to this analysis. }\end{array}$ \\
\hline & $\begin{array}{l}\text { Ignition of flammable gases in dome } \\
\text { void space }\end{array}$ & $\begin{array}{l}\text { See } \mathrm{Flammable} \mathrm{Gas} \mathrm{discussion} \mathrm{in} \mathrm{Section} 3.4 .2 .3 .1 \text {. This scenario is presumed to cause } \\
\text { a high over-pressure peak that damages the ventilation equipment and is analyzed in } \\
\text { Section } 3.4 .2-1.2 \text {. }\end{array}$ \\
\hline & $\begin{array}{l}\text { - Increased aerosol generation due to } \\
\text { mixer pump action and heat input }\end{array}$ & $\begin{array}{l}\text { Aerosol generation during the mixer pump process test is analyzed in } \\
\text { Section } 3.4 .2 .1 .1 \text {. }\end{array}$ \\
\hline & $\begin{array}{l}\text { - Plugging of filters with particulates } \\
\text { or moisture }\end{array}$ & $\begin{array}{l}\text { Increased particulates and moisture generated due to mixer pump operation that would } \\
\text { result in a HEPA filter plugging is analyzed in Section } 3.4 .2 .1 .1 \text {. }\end{array}$ \\
\hline & - Tank bump & $\begin{array}{l}\text { A tank bump resulting in HEPA filter blowout is analyzed in Section } 3.4 .2 .2 \text {. The tank } \\
\text { bump scenario is not considered representative of this class of accident and is } \\
\text { therefore analyzed separately. }\end{array}$ \\
\hline & $\begin{array}{l}\text { Tank dome collapse and breach of } \\
\text { containment }\end{array}$ & \multirow{2}{*}{$\begin{array}{l}\text { Tank dome collapse is analyzed in Section } 3.4 .2 .3 .7 \\
\text { The consequences of a breach of vent ducting leading to cont inuous unfiltered release } \\
\text { are bounded by the HEPA filter failure (3.4.2.1.2), and are with in guidel ines for an } \\
\text { unl ikely event (seismic initiator). Therefore, this scenario is not analyzed further. }\end{array}$} \\
\hline & $\begin{array}{l}\text { Breach of vent ducting due to seismic } \\
\text { event }\end{array}$ & \\
\hline $\begin{array}{l}\text { Tank bump } \\
\text { (Section } 3.4 .2 .2 \text { ) }\end{array}$ & $\begin{array}{l}\text { Uncontrolled waste overheating above } \\
\text { saturation temperature: } \\
\text { - Waste re-distribution causing poor heat } \\
\text { transfer from the sludge to the I iquid } \\
\text { or potential ALC draft tube blockage } \\
\text { - Loss of ventilation } \\
\text { - Increased waste temperature due to } \\
\text { mixer pump operation heat input } \\
\text { - Seismic event during pump operation }\end{array}$ & The tank bump scenario is analyzed in Section 3.4 .2 .2 \\
\hline \multirow[t]{8}{*}{$\begin{array}{l}\text { 3. Breach of } \\
\text { containment } \\
\text { (Section } 3.4 .2 .3 \text { ) }\end{array}$} & Excess vacuum draw down & $\begin{array}{l}\text { Tank bottom buckling that would result in a breach of containment is not a credible } \\
\text { scenario. The waste level in the tank prevents buckling. Waste will not be added or } \\
\text { removed during the test. }\end{array}$ \\
\hline & Pressure from a flammable gas burn & See Flammable Gas discussion in Section 3.4.2.3.1 \\
\hline & $\begin{array}{l}\text { Equipment dropped into the tank during } \\
\text { installation or removal }\end{array}$ & $\begin{array}{l}\text { USQDS IF-96-0018, TF-96-0461, TF-96-0448, and TF-96-0805 address equipment } \\
\text { instal lation. This analys is only deals with the process test (section } 3.4 .2 .3 .2 \text { ) and } \\
\text { does not address installation or removal of equipment. }\end{array}$ \\
\hline & Missiles from pumps (pump impeller failure) & Internal missiles are analyzed in section 3.4.2.3.3. \\
\hline & Erosion during mixer pump operation & $\begin{array}{l}\text { A breach of containment from erosion caused by mixer pump operation is analyzed } \\
\text { in Section } 3.4 .2 .3 .4 \text {. }\end{array}$ \\
\hline & $\begin{array}{l}\text { Material degradation due to high } \\
\text { temperature }\end{array}$ & The analysis of this scenario is addressed in Section 3.4.2.3.5. \\
\hline & Tank dome collapse due to overloading & The analysis of this scenario is addressed in Section 3.4.2.3.6. \\
\hline & Seismic event during pumping operations & $\begin{array}{l}\text { A seismic event leading to failure of the mixer pump support assembly, riser } \\
\text { extension, and/or spray wash system is analyzed in Section } 3.4 .2 .3 .7 \text {. }\end{array}$ \\
\hline \multirow{2}{*}{$\begin{array}{l}\text { 4. Over-pressurization } \\
\text { caused by } \\
\text { criticality } \\
\text { (Section } 3.4 .2 .4 \text { ) }\end{array}$} & Mixer pump action during operation & Criticality is analyzed in Section 3.4.2.4. \\
\hline & Waste settling after mixer pump shutdown & Criticality is analyzed in Section 3.4.2.4. \\
\hline
\end{tabular}

HEPA = high-efficiency particulate air (filter). 


\subsection{ACCIDENT ANALYSIS}

This section presents the formal development of potential accidents. Section 3.4.1 refers to the relevant sections of the TWRS BIO for the description of the consequence calculation methods common to the accidents analyzed. Section 3.4.2 presents analyses of the design basis accidents (DBA). No beyond design basis accidents (BDBA) were evaluated for the mixer pump test, for the reasons stated in Section 3.4.3.

\subsubsection{Methodology}

This section summarizes the radiological and toxicological consequence calculation assumptions used in the mixer pump test related accidents selected for further analysis in Section 3.3.2.4.

The calculation methods used for health effects determination are those documented in Van Keuren 1996 and Van Keuren et a1. 1996. Where assumptions vary from those of the TWRS BIO because of the mixer pump test, consequence calculation methods are summarized in Sections 3.4.2 and 3.4.3. Accident consequences are combined with the accident frequency and compared to the risk evaluation guidelines as shown in Tables 3-2 and 3-3 (excerpts of Tables 5.3-2 and $5.3-3$ of the TWRS BIO).

Table 3-2 Radiological Risk Evaluation Guidelines (Excerpted from TWRS BIO Table 5.3-2)

\begin{tabular}{|l|c|c|c|}
\hline Frequency category & $\begin{array}{c}\text { Frequency range } \\
\left(\mathrm{yr}^{-1}\right)\end{array}$ & $\begin{array}{c}\text { Onsite } \\
\mathrm{mSV} \\
(\text { rem })\end{array}$ & $\begin{array}{c}\text { Offsite } \\
\mathrm{mSv} \\
(\mathrm{rem})\end{array}$ \\
\hline Anticipated & $>10^{-2}$ to $\leq 10^{0}$ & $\begin{array}{c}5 \\
(0.5)\end{array}$ & $\begin{array}{c}1 \\
(0.1)\end{array}$ \\
\hline Unlikely & $>10^{-4}$ to $\leq 10^{-2}$ & $\begin{array}{c}50 \\
(5)\end{array}$ & $\begin{array}{c}5 \\
(0.5)\end{array}$ \\
\hline Extremely unlikely & $>10^{-6}$ to $\leq 10^{-4}$ & $\begin{array}{c}100 \\
(10)\end{array}$ & $\begin{array}{c}40 \\
(4)\end{array}$ \\
\hline
\end{tabular}

Table 3-3 Toxicological Risk Evaluation Guidelines (Excerpted from TWRS BIO Table 5.3-3)

\begin{tabular}{|c|c|c|c|}
\hline \multirow{2}{*}{ Frequency category } & \multirow{2}{*}{$\begin{array}{l}\text { Frequency range } \\
\qquad\left(y r^{-1}\right)\end{array}$} & \multicolumn{2}{|c|}{$\begin{array}{c}\text { Primary concentration } \\
\text { guidel ines }\end{array}$} \\
\hline & & Onsite & Offsite \\
\hline Anticipated & $>10^{-2}$ to $\leq 10^{0}$ & $\leq E R P G-1$ & $\leq P E L-T W A$ \\
\hline Unlikely & $>10^{-4}$ to $\leq 10^{-2}$ & $\leq E R P G-2$ & $\leq \mathrm{ERPG}-1$ \\
\hline Extremely unlikely & $>10^{-6}$ to $\leq 10^{-4}$ & $\leq \mathrm{ERPG}-3$ & $\leq \mathrm{ERPG}-2$ \\
\hline $\begin{array}{l}\text { ERPG }= \\
\text { PEL }= \\
\text { TWA }=\end{array}$ & $\begin{array}{l}\text { sponse Planning } \\
\text { Exposure Limit } \\
\text { d Average }\end{array}$ & es & \\
\hline
\end{tabular}




\subsubsection{Radiological Consequence Calculation Methodology}

The radiological consequence calculation methodology is provided in Section 5.3.1.1 of the TWRS BI0. This section provides the assumptions and data applicable to the consequence calculations for the mixer pump test. This specific information is provided in Tables 3-4 through 3-8.

Table 3-4 Centerline Atmospheric Dispersion Coefficients (excerpt from Van Keuren 1996)

\begin{tabular}{|l|c|c|c|}
\hline \multicolumn{1}{|c|}{ Maximum individual } & $\begin{array}{c}\text { Bounding } \\
(99.5 \text { percentile) } \\
\text { integrated } x / 0^{\prime}\left(\mathrm{s} / \mathrm{m}^{3}\right)\end{array}$ & $\begin{array}{c}\text { Bounding } \\
\text { integrated } x / Q^{\prime} \\
\left(\mathrm{s} / \mathrm{m}^{3}\right) \text { with } \mathrm{PM}^{*}\end{array}$ & $\begin{array}{c}\text { Maximum puff } \\
x / Q\left(1 / \mathrm{m}^{3}\right)\end{array}$ \\
\hline $\begin{array}{l}\text { Onsite } \\
\text { (sector and distance) }\end{array}$ & $\begin{array}{c}3.41 \mathrm{E}-02 \\
(\mathrm{E} 100 \mathrm{~m})\end{array}$ & $\begin{array}{c}1.13 \mathrm{E}-02 \\
(\mathrm{ESE} 100 \mathrm{~m})\end{array}$ & $\begin{array}{c}9.85 \mathrm{E}-03 \\
(\mathrm{E} 100 \mathrm{~m})\end{array}$ \\
\hline $\begin{array}{l}\text { Offsite } \\
\text { (sector and distance) }\end{array}$ & $\begin{array}{c}2.83 \mathrm{E}-05 \\
(\mathrm{~N} 8,760 \mathrm{~m})\end{array}$ & $\begin{array}{c}2.12 \mathrm{E}-05 \\
(\mathrm{~N} 8,760 \mathrm{~m})\end{array}$ & $\begin{array}{c}1.14 \mathrm{E}-07 \\
(\mathrm{NNW} 8,690 \mathrm{~m})\end{array}$ \\
\hline
\end{tabular}

*NRC Regulatory Guide 1.145 (NRC 1982) plume meander correction applied.

Table 3-5 Chronic Annual Average Atmospheric Dispersion Coefficients for 200 Area Tank Farms (excerpt from Van Keuren 1996)

\begin{tabular}{|l|c|}
\hline \multicolumn{1}{|c|}{ Maximum individual } & Integrated $x / \mathrm{Q}^{\prime}\left(\mathrm{s} / \mathrm{m}^{3}\right)$ \\
\hline $\begin{array}{l}\text { Onsite } \\
\text { (sector and distance) }\end{array}$ & $4.03 \mathrm{E}-04$ \\
\hline $\begin{array}{l}\text { Offsite } \\
\text { (sector and distance) }\end{array}$ & $1.24 \mathrm{E}-07$ \\
\hline
\end{tabular}


Table 3-6 In-Tank Concentration of the 11 Radionuclides Chosen for Inclusion in Accident Analysis (excerpt from Table 5.3-4 from the TWRS BI0, Aging Waste liquids and solids)

\begin{tabular}{|c|c|c|}
\hline \multirow{2}{*}{ Nuclide } & \multicolumn{2}{|c|}{ Activity concentration } \\
\cline { 2 - 3 } & AWF L iquids & AWF solids \\
\hline${ }^{60} \mathrm{Co}$ & $7.7 \mathrm{E}+05$ & $4.9 \mathrm{E}+08$ \\
\hline $90 \mathrm{Sr}$ & $5.6 \mathrm{E}+09$ & $2.9 \mathrm{E}+12$ \\
\hline $90 \mathrm{Y}$ & $5.6 \mathrm{E}+09$ & $2.9 \mathrm{E}+12$ \\
\hline $137 \mathrm{Cs}$ & $8.8 \mathrm{E}+10$ & $9.8 \mathrm{E}+10$ \\
\hline $154 \mathrm{Eu}$ & $\mathrm{a}$ & $1.1 \mathrm{E}+10$ \\
\hline $237_{\mathrm{Np}}$ & $9.2 \mathrm{E}+04$ & $9.9 \mathrm{E}+08$ \\
\hline $238 \mathrm{Pu}$ & $2.8 \mathrm{E}+03$ & $6.7 \mathrm{E}+07$ \\
\hline $239 \mathrm{Pu}$ & $1.2 \mathrm{E}+06$ & $4.4 \mathrm{E}+08$ \\
\hline $241 \mathrm{Pu}$ & $3.4 \mathrm{E}+05$ & $1.7 \mathrm{E}+09$ \\
\hline $241_{\mathrm{Am}}$ & $1.1 \mathrm{E}+06$ & $1.1 \mathrm{E}+10$ \\
\hline $244 \mathrm{Cm}$ & $1.1 \mathrm{E}+04$ & $6.1 \mathrm{E}+07$ \\
\hline
\end{tabular}

a) No valid sample result exists. Analysis indicates this isotope, in the

liquids, is a negligible contributor to dose.

b) The $239 \mathrm{pu}$ activity concentration also includes $240 \mathrm{Pu}$.

AWF = Aging Waste Facility

The radionuclides concentration data in Table 3-6 represents bounding activity concentrations for dose assessments. The data are bounding for a11 the AWF tanks and are, therefore, conservative for 241-AZ-101.

Tank 241-AZ-101 contains radioactive materials in the form of 1 iquid and sludge. Table 3-7 presents the inhalation and ingestion Unit Liter Doses (ULD)s for the liquid and solid constituents of AWF tank waste. The inhalation and ingestion ULDs were reported in Cowley 1996. They were calculated with dose conversion factors in EPA 1988 using the GENII computer program (Napier et al. 1988)

Table 3-7 Unit Liter Doses for Inhalation and Ingestion (excerpt from Table 5.3-5 of the TWRS BI0)

\begin{tabular}{|c|c|c|}
\hline Composite & $\begin{array}{c}\text { Inhalation ULD } \\
(\mathrm{SV} / \mathrm{L})\end{array}$ & $\begin{array}{c}\text { Ingestion ULD } \\
(\mathrm{SV}-\mathrm{m} 3 / \mathrm{s}-\mathrm{L})\end{array}$ \\
\hline $\begin{array}{c}\text { Aging waste facility } \\
\text { liquids }\end{array}$ & $1.4 \mathrm{E}+03$ & 0.092 \\
\hline $\begin{array}{c}\text { Aging waste facility } \\
\text { solids }\end{array}$ & $1.7 \mathrm{E}+06$ & 8.1 \\
\hline
\end{tabular}

*Includes 24 hour ingestion of fruits and vegetables, ground shine, inadvertent soil ingestion, and inhalation of material re-suspended from the ground. 
Table 3-8 Release Durations for which the Maximum Puff $x / Q$ can be Applied

\begin{tabular}{|c|c|}
\hline Release & Duration \\
\hline Onsite receptor, ground-level release & $\leq 3.5 \mathrm{~s}$ \\
\hline Offsite receptor, ground-level release & $\leq 250 \mathrm{~s}$ \\
\hline
\end{tabular}

NOTE: The information in this table is from Van Keuren et al. 1996.

\subsubsection{Toxicological Consequence Calculation Methodology}

The toxicological consequence calculation methodology is provided in Section 5.3.1.2 of the TWRS BIO and defined as the toxicological Sum of Fractions (SOF) methodology. This methodology is based on the methodology provided in Van Keuren et a1. 1996. This section provides the assumptions and data applicable to the consequence calculations for the mixer pump test. This specific information is provided in Tables 3-9 and 3-10.

Since the toxicological Sum of Fractions (SOF) methodology does not directly correlate to single, chemical-specific emergency response planning guideline (ERPG) values, the toxicological SOF values calculated for a specific accident do not provide enough information for emergency response purposes. Depending upon the type, form, and location of waste released, the 24 analytes used in the toxicological SOF methodology may be reduced to a smaller set of peak contributors to be initially considered for emergency response purposes. For example, in double-shell tank liquids, there are five peak analytes ( $\mathrm{Na}, \mathrm{NaOH}, \mathrm{NH} 3, \mathrm{TOC}$, and $\mathrm{U})$. For double shell tank solids, there are twelve peak analytes $(\mathrm{Na}, \mathrm{Cd}, \mathrm{NaOH}, \mathrm{Co}, 0 x a 7$ ate, $\mathrm{Cr}, \mathrm{AS}, \mathrm{Tl}, \mathrm{U}$, Be, TOC, and Se). Determination of emergency response actions relies upon the location of the release, the potential release quantity, consideration of the primary (peak) analytes, and the location of any potentially affected individuals (onsite or offsite). The computer code EPIcode is used at the Hanford Site for emergency response, but not for SOF methodology discussed here. 
Table 3-9 Tank Waste Liquids and Solids Analyte Concentrations

\begin{tabular}{|c|c|c|}
\hline \multirow{2}{*}{ Analyte } & \multicolumn{2}{|c|}{ Composite concentration $(\mathrm{g} / \mathrm{L})$} \\
\hline & DST solids ${ }^{c}$ & DST $t$ iquids ${ }^{c}$ \\
\hline Ammonia $\left(\mathrm{NH}_{3}\right)$ & $6.6 E+00$ & $7.1 E+00$ \\
\hline Antimony (Sb) & $9.2 \mathrm{E}-01$ & $6.4 E-03$ \\
\hline Arsenic (As) & $5.7 E+00$ & $1.1 \mathrm{E}-02$ \\
\hline Barium (Ba) & $5.9 E+00$ & $3.3 \mathrm{E}-02$ \\
\hline Beryllium (Be) & $2.4 E-01$ & $3.8 \mathrm{E}-03$ \\
\hline Cadmium (cd) & $2.6 E+01$ & $7.0 \mathrm{E}-02$ \\
\hline Calcium (Ca) & $2.6 \mathrm{E}+01$ & $1.3 E+00$ \\
\hline Cerium (Ce) & $2.6 \mathrm{E}+00$ & $5.8 \mathrm{E}-02$ \\
\hline Chromium $\left(\mathrm{Cr}^{+3}\right)$ & $1.5 E+02$ & $a$ \\
\hline Cobalt (Co) & $4.4 E+00$ & $8.8 E-03$ \\
\hline Cyanide (CN) & $4.7 E-01$ & $9.1 E-02$ \\
\hline Dysprosium (Dy) & a & a \\
\hline Lanthanum (La) & $3.0 E+01$ & $1.0 E+00$ \\
\hline Mercury ( $\mathrm{Hg})$ & $1.2 E-01$ & $2.4 E-04$ \\
\hline Neodymium (Nd) & $7.0 \mathrm{E}+00$ & $5.6 \mathrm{E}-03$ \\
\hline Oxalate $\left(\mathrm{C}_{2} \mathrm{O}_{4}\right)$ & $2.8 \mathrm{E}+02$ & a \\
\hline Selenium (Se) & $1.9 E+00$ & $2.8 \mathrm{E}-01$ \\
\hline Sodium hydroxide (NaOH) & $2.3 E+02$ & $2.1 \mathrm{E}+02$ \\
\hline Sodium (Na) - $\mathrm{NaOH}^{\mathrm{b}}$ & $3.5 \mathrm{E}+02$ & $2.1 E+02$ \\
\hline Tellurium (Te) & $9.3 \mathrm{E}-01$ & $2.7 \mathrm{E}-03$ \\
\hline Thall ium (Tl) & $1.5 \mathrm{E}+01$ & $3.7 \mathrm{E}-02$ \\
\hline Total organic carbon (TOC)-oxalate & $7.5 \mathrm{E}+01$ & $4.0 \mathrm{E}+01$ \\
\hline Uranium (U) & $4.4 E+01$ & $1.1 E+01$ \\
\hline Vanadium $(V)$ & $1.2 \mathrm{E}-01$ & $2.1 E-03$ \\
\hline
\end{tabular}

NOTE: The information in this table is from sable 5.3-6 from the TWRS BIO.

a) The best available data indicates there is not a significant concentration of this analyte in the composite.

b) To avoid counting the same analyte twice, the oxalate concentration was subtracted from the TOC concentration and $\mathrm{NaOH}$ was subtracted from the Na concentration.

c) The Aging Waste Facility tanks, including 241-AZ-101, are grouped with the other double-shell tanks for toxicological analys is.

DST = double-shell tank. 
Table 3-10 Sum-of-Fractions for Risk EvaTuation Guidelines for a Unit Release of Waste Chemicals (excerpt from Table 5.3-8 of the TWRS BI0)

\begin{tabular}{|c|c|c|c|c|}
\hline \multirow{2}{*}{$\begin{array}{c}\text { Tank waste } \\
\text { type }\end{array}$} & \multirow{2}{*}{$\begin{array}{c}\text { Maximum } \\
\text { individual }\end{array}$} & \multicolumn{3}{|c|}{$\begin{array}{l}\text { Sum-of-fractions (s/L) as a function of } \\
\text { accident frequency }(1 / y r)\end{array}$} \\
\hline & & $1-10^{-2}$ & $10^{-2}-10^{-4}$ & $10^{-4}-10^{-6}$ \\
\hline \multicolumn{5}{|c|}{ DST solid or liquid continuous release } \\
\hline \multirow[t]{2}{*}{ DST 1 iquids } & Onsite & $1.0 \mathrm{E}+04$ & $7.5 \mathrm{E}+02$ & $2.1 \mathrm{E}+02$ \\
\hline & Offsite & $8.4 \mathrm{E}+00$ & $8.4 E+00$ & $6.2 \mathrm{E}-01$ \\
\hline \multirow[t]{2}{*}{ DST solids } & Onsite & $1.8 E+04$ & $3.3 E+03$ & $6.3 \mathrm{E}+02$ \\
\hline & Offsite & $1.9 E+02$ & $1.5 \mathrm{E}+01$ & $2.8 \mathrm{E}+00$ \\
\hline \multicolumn{5}{|c|}{ DST solid or liquid puff release } \\
\hline \multirow[t]{2}{*}{ DST 1iquids } & Onsite & $2.9 \mathrm{E}+03$ & $2.2 \mathrm{E}+02$ & $6.0 \mathrm{E}+01$ \\
\hline & Offsite & $3.4 \mathrm{E}-02$ & $3.4 \mathrm{E}-02$ & $2.5 \mathrm{E}-03$ \\
\hline \multirow[t]{2}{*}{ DST solids } & Onsite & $5.2 \mathrm{E}+03$ & $9.7 \mathrm{E}+02$ & $1.8 \mathrm{E}+02$ \\
\hline & Offsite & $7.7 \mathrm{E}-01$ & $5.9 \mathrm{E}-02$ & $1.1 \mathrm{E}-02$ \\
\hline
\end{tabular}

Note: The Aging Waste Facility tanks are grouped with the other double-shell tanks for the toxicological analysis.

\subsubsection{Design Basis Accidents}

\subsubsection{Unfiltered Release of Radionuclides and Toxic Aerosols From the Tank}

\subsection{HEPA Filter Plugging Due to Mixer Pump Aerosols Generation}

Wong and Waters 1994 attempted to evaluate the ability of a ventilation system to provide adequate de-entrainment of liquid and solid aerosols during mixer pump operations, and to determine if the radioactive aerosols will overload the HEPA filters.

Wong and Waters 1994 concluded that insufficient data exist to confidently estimate the magnitude of aerosol generation during tank waste mixer pump operations. However, it was noted by Wong and Waters 1994 that aerosol generation would not be expected to be a severe problem during ful1scale operations due to (1) the existing cooling system being able to handle the additional heat generated from mixer pump operations so that significant vapor rates are not expected to carry aerosols beyond the condensers, (2) aerosol testing conducted in Tank 241-AP-102 did not indicate a significant increase in aerosols, and (3) development tests indicate that Project W-030 will also adequately control the aerosol generation (HNF-SD-WM-SARR-039 Draft).

In addition, as stated in a letter report by Ligotke et a1. 1994, analysis shows the operation of the two mixer pumps may increase the generation of aerosols slightly over normal operations without air lift circulators (ALC)s but that the aerosol generation would be less than that expected for normal operation with ALCS. 
The values used in calculating the amount of aerosolized liquid in the vapor space bound operations with the mixer pumps alone, the ALCs alone, and the mixer pumps and ALCs together (see Section 3.4.2.1.2.3B). Since the consequences do not approach the risk evaluation guidelines, confirmation testing is not required at this time.

Two off-normal situations are considered. The first is the failure of the ventilation system heater (in either the 241-A-702 or W-030 systems). This failure would result in condensation build-up in the ventilation ducting. The second failure scenario considered is the situation where mixer pump and/or ALC aerosol generation rates exceed the upstream equipment's (de-entrainers in the 241-A-702 system, or the high-efficiency mist eliminator (HEME) and highefficiency gas absorber (HEGA) in the $W-030$ system) capabilities to prevent wetting of HEPA filters (by allowing increased liquid carryover). This could then create an excessive differential pressure across the HEPA filters and subsequent failure of the filters, resulting in a release of radioactive particulates. This release is mitigated through the implementation of LCO 3.4.3 (Heubach 1996), addressing radioactive material maximum loading on HEPA filters (see following Section 3.4.2.1.2).

The risk from HEPA filter damage caused by dust or moisture overload, and subsequent over-pressure, is reduced by Surveillance Requirement SR 3.4.1.1 (Heubach 1996). This requirement includes HEPA filter operability surveillance by checking the pressure drop across the filters every 12 hours. This pressure drop should not exceed the operability requirement values for the system. Therefore, any trending toward HEPA filter plugging due to mixer pump and/or ALC operation will be detected, and corrective action taken.

\subsection{HEPA Filter Failure Due to Over-pressure}

\subsection{HEPA Filter Failure Due to Over-pressure Accident Scenario}

The HEPA Filter Failure due to over-pressure accident is an AWF Design Basis Accident documented in Section 5.3.2.14 of the TWRS BIO and supported by Ryan 1996. However, this accident scenario requires additional evaluation due to the assumption that mixer pump operation could result in the release of solids entrained in the liquid during a continuous un-filtered release. Thus, the potential release of solid (as well as liquid) waste requires a reassessment of the consequences calculated in the TWRS BIO.

This section evaluates the consequences of an un-prevented HEPA filter failure due to over-pressure accident scenario using the same initial assumptions as were used in the TWRS BIO analysis (i.e., using the maximum radionuclide loading on HEPA filters equating to a dose rate of $200 \mathrm{mrem} / \mathrm{h}$ ). Therefore, all consequences given in this SARR for this scenario are considered to contain some degree of mitigation. Filter failure due to overpressure is postulated to require a mechanism such as hydrogen deflagration, which is an anticipated event without controls (see Section 5.3.2.14 of the TWRS BIO). The estimated frequency for this accident scenario (deflagration in Tank 241-AZ-101 during the mixer pump test with a complete filter failure due to over-pressure), was determined to be extremely unlikely. This frequency determination is based on the configuration of the ventilation systems and the duration of the mixer pump test. For the Project W-030 ventilation system (see HNF-SD-WM-SARR-039 [Draft] for additional details), 
there are four filtration elements in series (a HEME, two HEPA filters, and a HEGA), remotely located from each of the AWF tanks that would have to fail to varying degrees for this accident scenario. The varying degrees of failure for these pieces of equipment relate to the physical mechanisms involved for each component during a pressure pulse. For the HEME and the HEGA, which are not designed specifically for particulate filtration, the pressure pulse results in a temporary decrease in decontamination efficiency and carryover of additional liquids through the equipment. For the analysis regarding the HEPA filters, however, the pressure pulse results in a permanent rupture of the paper filtration media. For the 702-A ventilation system, the pressure pulse from a deflagration accident would be dampened by approximately one-quarter mile of 20-inch diameter ventilation ducting and two de-entrainers (similar "failure" mechanism as discussed above for a HEGA and/or a HEME) (See Section 2.4.3.7.1 of Appendix B of the TWRS BIO for additional details). The accident frequency is further reduced when considering that the mixer pump test has an anticipated duration of 1300 hours, or 0.15 year. Based on the above considerations, the likelihood of a deflagration event occurring during the approximate 1300 hour time period of the mixer pump test with a sufficiently powerful pressure pulse to fail the HEPA filters is considered to be extremely unlikely (frequency of $10^{-4}$ to $10^{-6}$ per year). These findings are also applicable to the currently anticipated $W-030$ ventilation system (four elements in series that would have to fail to varying degrees).

In this scenario, the failure due to over-pressure of a single bank of ventilation system filters is assumed to be followed by the active ventilation of the tank headspace. This would be a puff release (i.e., the loss of the HEPA filters) followed by a continuous release of unfiltered airflow as the system continues to operate for 24 hours. A 24 hour release is equivalent to two shift changes. It is assumed that the filter failure due to over-pressure goes without intervention (is undetected) during this time.

The accident involving failure due to over-pressure of the inlet HEPA filters (only existing on the $W-030$ vent $i l$ ation system) was considered during the HAZOP study. It is true that this accident has a higher frequency than the accident involving the downstream filters, but the consequences are significantly lower. The consequences of the HEPA filter failure due to overpressure evaluated in this SARR derive from two separate source terms:

(1) radioactivity previously entrained on the HEPA filters and released during the accident, and (2) radioactivity released from continued 24 hours operation of the ventilation system with no filtration. The consequences are dominated by the 24-hour release scenario. It is unlikely that the inlet HEPA filter would be as heavily loaded as the downstream HEPA filters, but even if it were, the consequences of an inlet filter failure due to over-pressure would be about three orders of magnitude less than a complete failure of the downstream filtration system. The ventilation system would continue to operate, provide negative pressure on the tank, and exhaust tank headspace vapors through the downstream HEPA filters.

The first step of the analysis is to evaluate the HEPA filter loading of particulates. To determine the consequences of releasing the accumulated particulates in a puff release, it is assumed that only liquid waste constituents accumulate on the filters during normal service (i.e., waste which re-condenses downstream of the de-entrainers or the HEME/HEGA (241-A-702 or $W-030$ ventilation systems, respectively). The next step is to evaluate the continuous flow contribution, conservatively assuming mixed waste aerosols 
(term "mixed waste" used in this document to denote a composite of 1iquids and solids as opposed to the regulatory usage of radioactive and hazardous wastes) are released due to mixer pump re-suspension. The final step is to determine the radiological and toxicological consequences of this accident scenario.

\subsection{HEPA Filter Failure Due to Over-pressure Accident Source Term}

\section{A. Source Term from the Filter}

The consequences of a HEPA filter failure due to over-pressure are dependent upon the initial filter loading and the loading in the ventilation ductwork and other components. For the ventilation system upgrade provided by Project $W-030$, the amount of material released would be that from a single bank of filters (two HEPA filters in series in one of two independent, parallel ventilation trains, with only one filter bank will be used at a time), and three additional volume equivalents to account for the loading in the HEME, HEGA, and the ventilation duct work. Therefore, the number of HEPA filter volumes released for Project $W-030$ would be 6 . For the 241-A-702 ventilation system, Van Vleet $1996 \mathrm{a}$ assumes the number of HEPA filter volumes is 30, considering 6 banks of 5 HEPA filter volume equivalents (2 HEPAs, 2 deentrainers, and one volume equivalent for ductwork), which is more limiting. This is conservative since 5 of the banks contain only 2 HEPAs and no deentrainers.

From the same calculation note, the maximum total amount of material potentially released is found to be $5.62 \mathrm{E}-3 \mathrm{~L}$. This result is based on considering ${ }^{137} \mathrm{Cs}$ as the predominant gamma emitter for the AWF source material for the liquids (the other gamma emitters have much smaller concentrations). In addition, a maximum loading on the filter is assumed to be no greater than the activity that would result in $200 \mathrm{mrem} / \mathrm{h}$ on contact for each filter or component, based on maximum allowable loading before filter change-out (LCO $3.4 .3)$.

\section{B. Source Term Released from Unfiltered Operation of the Ventilation System}

For the ventilation system upgrade provided by Project $W-030$, the design airflow through the ventilation system is $4.7 \times 10^{-1} \mathrm{~m}^{3} / \mathrm{s}(1,000 \mathrm{scfm})$. Also for Project $W-030$, the rate used for the unfiltered continuous release of the ventilation system assumes the simultaneous operation of both fans or $9.4 \mathrm{x}$ $10^{-1} \mathrm{~m}^{3} / \mathrm{s}(2,000 \mathrm{scfm})$ to bound the scenario. For the 24l-A-702 ventilation system, the design airflow through the system is $1.89 \mathrm{~m}^{3} / \mathrm{s}(4,000 \mathrm{scfm})$, which is more limiting.

With the mixer pumps running in Tank 241-AZ-101 during unfittered operation of the ventilation system, it is assumed that the supernatant and sludge is homogeneously mixed. This requires modification of the ULDs listed in Table 3-7 to reflect the presence of sludge particles in aerosols released to the tank headspace. The ULDs for the 1 iquid/sludge mixture are calculated using the 1iquid and solid ULDs given in Table 3-7 and the volume fractions of liquid and sludge in Tank 24l-AZ-101,

$$
U L D_{\text {mix }}=\left(f_{1} \times U L D_{\text {liq }}\right)+\left(f_{2} \times U L D_{\text {sol }}\right)
$$


where:

$$
\begin{array}{ll}
f_{1} & =\begin{array}{l}
0.96, \text { volume fraction of liquid in Tank 241-AZ-101 (data } \\
\text { from TWRS BI0, Appendix B, Table 2-3) }
\end{array} \\
f_{2} & =\begin{array}{l}
0.04, \text { volume fraction of solids in Tank 241-AZ-101 (data } \\
\text { from TWRS BI0, Appendix B, Table 2-3) }
\end{array} \\
U_{L D_{\text {liq }}} & =\text { unit liter dose for AWF liquids (Table 3-7) } \\
U_{L D} & =\text { unit liter dose for AWF solids (Table 3-7) }
\end{array}
$$

Using the above formula, the Inhalation and Ingestion ULDs for Tank 24l-AZ-101 mixed liquids and solids are calculated to be:

$$
\begin{gathered}
\text { Inhalation } U L D_{\text {mix }}(\mathrm{SV} / \mathrm{L})=6.9 \times 10^{4} \\
\text { Ingestion } U L D_{\text {mix }}\left(\mathrm{SV}-\mathrm{m}^{3} / \mathrm{s}-\mathrm{L}\right)=0.4
\end{gathered}
$$

The source term released from unfiltered operation of the ventilation system is drawn from all four AWF tanks, but the mixer pumps operate only in one tank. Therefore, the ULDs for the unfiltered release must be adjusted to represent the aerosols from one mixed tank and three un-mixed tanks,

$$
U L_{\text {mix }}^{\prime}=\left(0.25 \times U_{\text {mix }}\right)+\left(0.75 \times \mathrm{ULD}_{\text {liq }}\right)
$$

The Inhalation and Ingestion ULDs for the aerosols released from unfiltered operation of the ventilation system are calculated to be:

$$
\begin{gathered}
\text { Inhalation ULD' }{ }_{\text {mix }}(\mathrm{SV} / \mathrm{L})=1.8 \times 10^{4} \\
\text { Ingestion } U \mathrm{LD}^{\prime}{ }_{\operatorname{mix}}\left(\mathrm{SV}-\mathrm{m}^{3} / \mathrm{s}-\mathrm{L}\right)=0.17
\end{gathered}
$$

\subsection{HEPA Filter Failure Due to Over-pressure Accident Offsite Radiological Consequence Analys is}

\section{A. Offsite Radiological Consequence for a Puff Release from Filter Failure Due to Over-Pressure}

The TEDE for inhalation for offsite consequences for the loss of a HEPA filter can be found using the following Equation:

$$
D_{\text {inh-filter }}(S V)=Q(L) \times \frac{X}{Q^{\prime}}\left(\frac{s}{m^{3}}\right) \times R\left(\frac{m^{3}}{s}\right) \times U L D_{\text {inh }}\left(\frac{S V}{L}\right)
$$

where:

$$
\begin{array}{ll}
D_{\text {inh-filter }} & =\text { dose due to inhalation } \\
Q^{\prime} & \text { respirable source term } \\
X / Q^{\prime} & =\text { atmospheric dispersion coefficient } \\
\mathrm{R} & =\text { breathing rate } \\
U^{\prime} D_{\text {inh }} & =\text { inhalation unit liter dose }
\end{array}
$$


The type of material accumulating on the AWF filters is from the AWF liquids being deposited on the filter from normal ventilation air flow. The total effective dose equivalent (TEDE) for offsite consequence is found to be:

$$
\begin{gathered}
D_{\text {inh-filter }}=\left(5.62 \times 10^{-3} \mathrm{~L}\right) \times\left(2.83 \times 10^{-5} \mathrm{~s} / \mathrm{m}^{3}\right) \times \\
\left(3.3 \times 10^{-4} \mathrm{~m}^{3} / \mathrm{s}\right) \times\left(1.4 \times 10^{3} \mathrm{~Sv} / \mathrm{L}\right) \\
D_{\text {inh-filter }}=7.3 \times 10^{-8} \mathrm{~Sv}\left(7.3 \times 10^{-6} \mathrm{rem}\right)
\end{gathered}
$$

where:

$Q=V_{\text {released }}=5.62 \times 10^{-3} \mathrm{~L}$ (Section 3.4.2.1.2.2)

$X / Q^{\prime}$ (Table $3-4$, bounding offsite $)=2.83 \times 10^{-5} \mathrm{~s} / \mathrm{m}^{3}$

$\mathrm{R}=$ acute breathing rate $($ Van Keuren 1996$)=3.3 \times 10^{-4} \mathrm{~m}^{3} / \mathrm{s}$

ULD' $_{\text {liquid-inh }}($ Table $3-7)=1.4 \times 10^{3} \mathrm{SV} / \mathrm{L}$

These inputs are consistent with those used in Ryan 1996.

The TEDE for ingestion for offsite consequences for the loss of a HEPA filter can be found using the following equation:

$$
D_{\text {ing }}(S V)=Q(L) \times \frac{X}{Q^{\prime}}\left(\frac{s}{m^{3}}\right) \times U L D_{i n g}\left(\frac{S v^{m^{3}}}{s-L}\right)
$$

where:

$$
\begin{array}{ll}
D_{i n g} & =\text { dose due to ingestion } \\
Q^{\prime} & =\text { respirable source term } \\
X / Q^{\prime} & =\text { atmospheric dispersion coefficient } \\
\text { ULD } & =\text { ingestion unit liter dose. }
\end{array}
$$

The TEDE for offsite consequence is found to be:

$$
\begin{aligned}
& D_{\text {ing filter }}=\left(5.62 \times 10^{-3} \mathrm{~L}\right) \times\left(2.83 \times 10^{-5} \mathrm{~s} / \mathrm{m}^{3}\right) \times\left(0.092 \mathrm{SV}-\mathrm{m}^{3} / \mathrm{s}-\mathrm{L}\right) \\
& D_{\text {ing filter }}=1.4 \times 10^{-8} \mathrm{~Sv}\left(1.4 \times 10^{-6} \mathrm{rem}\right)
\end{aligned}
$$

where:

$$
U_{\text {Liquid-ing }}(\text { Table } 3-7)=0.092 \mathrm{~Sv}-\mathrm{m}^{3} / \mathrm{s}-\mathrm{L}
$$




\section{B. Offsite Radiological Consequence for 24 Hour Continuous Venting After Filter Failure due to Over-pressure}

The duration of 24 hours was selected to represent the continued venting of the system since this represents two shift changes. Radioactive material is carried from the tank waste material into the tank vapor space atmosphere through several physical processes. Only a fraction of the liquid waste constituents, the partition fraction (PF), in a tank will migrate into the vapor space atmosphere. The PF for AWF tanks is found to be $1 \times 10^{-8}$ under the worst case liquid waste agitation conditions (Ryan 1996, Appendix A). The value bounds severe waste surface agitation, such as ALC operation and tank boiling.

The amount of mixed waste released by operating the ventilation system can be found by:

$$
\begin{gathered}
V_{\text {release rate }}=V_{\text {rate }} \times P F \\
V_{\text {release rate }}=\left(1.89 \times 10^{3} \mathrm{~L} / \mathrm{s}\right) \times\left(1 \times 10^{-8}\right) \\
V_{\text {release rate }}=1.89 \times 10^{-5} \mathrm{~L} / \mathrm{s}
\end{gathered}
$$

where:

$$
\begin{aligned}
& V_{\text {rate }}=1.89 \times 10^{3} \mathrm{~L} / \mathrm{s}(4,000 \mathrm{scfm}) \\
& P F\left(\text { Ryan 1996) }=1 \times 10^{-8}\right.
\end{aligned}
$$

The dispersion coefficients $\left(X / Q^{\prime}\right)$ to be used for the 12-hour and 24-hour releases are calculated from the methodology presented in Van Keuren 1996.

\section{$x / 0^{\prime}$, Offsite (24-hour)}

To determine the $x / Q^{\prime}$ for the 24 -hour release, the logarithmic interpolation procedure described in Van Keuren 1996 is used to correctly identify the proper $x / Q^{\prime}$ to be used. The $X / Q^{\prime}$ used for the 2 -hour release is $2.12 \times 10^{-5} \mathrm{~s} / \mathrm{m}^{3}$ to account for plume meander (Table 3-4). Using the equation from Van Keuren 1996 yields:

$$
\frac{\log \left(2.12 \times 10^{-5}\right)-\log \left(\times / 0^{\prime} 24-\text { hour }\right)}{\log \left(2.12 \times 10^{-5}\right)-\log \left(1.24 \times 10^{-7}\right)}=\frac{\log (2 \text {-hour })-\log (24 \text {-hour })}{\log (2 \text {-hour })-\log (8,760 \text {-hour })}
$$

The offsite $X / Q^{\prime}$ (24-hour) is $4.62 \times 10^{-6} \mathrm{~s} / \mathrm{m}^{3}$.

The TEDE for inhalation for offsite consequences for the continued operation for 24 hours after the loss of a HEPA filter can be found using the same equation as was used for inhalation consequences in Section 3.4.2.1.2.3.A. 
TEDE for offsite consequence for 24 hour exposure is found to be:

$$
\begin{gathered}
D_{\text {inh vent }}=\left(1.89 \times 10^{-5} \mathrm{~L} / \mathrm{s}\right) \times\left(4.62 \times 10^{-6} \mathrm{~s} / \mathrm{m}^{3}\right) \times\left(2.7 \times 10^{-4} \mathrm{~m}^{3} / \mathrm{s}\right) \times \\
\left(1.8 \times 10^{4} \mathrm{~Sv} / \mathrm{L}\right) \times(24 \mathrm{~h}) \times(60 \mathrm{~min} / \mathrm{h}) \times(60 \mathrm{~s} / \mathrm{min}) \\
D_{\text {inh vent }}=3.7 \times 10^{-5} \mathrm{~Sv}\left(3.7 \times 10^{-3} \mathrm{rem}\right)
\end{gathered}
$$

where:

$$
\begin{aligned}
& Q=V_{\text {release rate }}=1.89 \times 10^{-5} \mathrm{~L} / \mathrm{s} \\
& X / Q^{\prime} \text { (offsite 24-hour) }=4.62 \times 10^{-6} \mathrm{~s} / \mathrm{m}^{3} \\
& \mathrm{R}=\text { chronic breathing rate }(\text { Van Keuren } 1996)=2.7 \times 10^{-4} \mathrm{~m}^{3} / \mathrm{s} \\
& \left.\mathrm{ULD}^{\prime}{ }_{\text {mix-inh }} \text { (Section } 3.4 .2 .1 .2\right)=1.8 \times 10^{4} \mathrm{~Sv} / \mathrm{L} .
\end{aligned}
$$

The TEDE for ingestion for offsite consequences for the continued operation for 24 hours after the loss of a HEPA filter can be found using the same equation as was used for ingestion consequences in Section 3.4.2.1.2.3.A.

The TEDE for offsite consequence is found to be:

$$
\begin{gathered}
D_{\text {ing vent }}=\left(1.89 \times 10^{-5} \mathrm{~L} / \mathrm{s}\right) \times\left(4.62 \times 10^{-6} \mathrm{~s} / \mathrm{m}^{3}\right) \times \\
\left(0.17 \mathrm{~Sv}-\mathrm{m}^{3} / \mathrm{s}-\mathrm{L}\right) \times(24 \mathrm{~h}) \times(3,600 \mathrm{~s} / \mathrm{h}) \\
D_{\text {ing vent }}=1.3 \times 10^{-6} \mathrm{~Sv}\left(1.3 \times 10^{-4} \mathrm{rem}\right)
\end{gathered}
$$

where:

$$
\text { ULD' }_{\text {mix-ing }}\left(\text { Section 3.4.2.1.2) }=0.17 \mathrm{SV}-\mathrm{m}^{3} / \mathrm{s}-\mathrm{L}\right.
$$

\section{Total Offsite Radiological Consequence}

Total offsite consequences ( $D_{\text {offsite }}$ ) for HEPA filter failure due to overpressure is the sum of the filter offsite consequences and the unfiltered operation of the ventilation system offsite consequences. The total offsite consequence is found to be:

$$
\begin{gathered}
D_{\text {offsite }}=D_{\text {inh-filter }}+D_{\text {ing filter }}+D_{\text {inh vent }}+D_{\text {ing vent }} \\
D_{\text {offsite }}=7.3 \times 10^{-8} \mathrm{~Sv}+1.4 \times 10^{-8} \mathrm{~Sv}+ \\
3.7 \times 10^{-5} \mathrm{~Sv}+1.3 \times 10^{-6} \mathrm{~Sv} \\
D_{\text {offsite }}=3.8 \times 10^{-5} \mathrm{~Sv}\left(3.8 \times 10^{-3} \mathrm{rem}\right)
\end{gathered}
$$




\subsection{HEPA Filter Failure Due to Over-pressure Onsite Radiological Consequence}

\section{A. Onsite Radiological Consequence For a Puff Release from Filter Failure Due to Over-Pressure}

The TEDE for onsite consequences for the HEPA filter is found using the same methodology and equation (see Section 3.4.2.1.2.3.A) as for the offsite. The TEDE for onsite consequence is found to be:

$$
\begin{gathered}
D_{\text {inh-filter }}=\left(5.62 \times 10^{-3} \mathrm{~L}\right) \times\left(3.41 \times 10^{-2} \mathrm{~s} / \mathrm{m}^{3}\right) \times \\
\left(3.3 \times 10^{-4} \mathrm{~m}^{3} / \mathrm{s}\right) \times\left(1.4 \times 10^{3} \mathrm{~Sv} / \mathrm{L}\right) \\
D_{\text {inh-filter }}=8.8 \times 10^{-5} \mathrm{SV}\left(8.8 \times 10^{-3} \mathrm{rem}\right)
\end{gathered}
$$

where:

$$
\begin{aligned}
& Q=V_{\text {released }}=5.62 \times 10^{-3} \mathrm{~L} \\
& X / Q^{\prime} \text { (Table } 3-4 \text {, bounding onsite) }=3.41 \times 10^{-2} \mathrm{~s} / \mathrm{m}^{3} \\
& \mathrm{R}=\text { acute breathing rate (Van Keuren } 1996)=3.3 \times 10^{-4} \mathrm{~m}^{3} / \mathrm{s} \\
& \text { ULD' }{ }_{\text {(iquid-inh }}(\text { Table } 3-7)=1.4 \times 10^{3} \mathrm{SV} / \mathrm{L}
\end{aligned}
$$

B. Onsite Radiological Consequence for 24 Hour Continuous Release After Filter Failure Due to Over-pressure.

Since shifts are limited to 12 hours, this is assumed to be the maximum exposure to the onsite receptor.

\section{$x / 0^{\prime}$, Onsite (12-hour)}

To determine the $x / Q^{\prime}$ for the 12 -hour release, the logarithmic interpolation procedure described in Van Keuren 1996 is used to correctly identify the proper $X / Q^{\prime}$ to be used. The $x / Q^{\prime}$ used for the 2 -hour release is $1.13 \times 10^{-2} \mathrm{~s} / \mathrm{m}^{3}$ to account for plume meander (Table 3-4). Using the equation from Van Keuren 1996 yields:

$\frac{\log \left(1.13 \times 10^{-2}\right)-\log \left(\times / 0^{\prime} 12-\text { hour }\right)}{\log \left(1.13 \times 10^{-2}\right)-\log \left(4.03 \times 10^{-4}\right)}=\frac{\log (2-\text { hour })-\log (12 \text {-hour })}{\log (2 \text {-hour })-\log (8,760 \text {-hour })}$

The onsite $X / Q^{\prime}\left(12\right.$-hour) is $5.54 \times 10^{-3} \mathrm{~s} / \mathrm{m}^{3}$.

Using the same equations as in Section 3.4.2.1.2.3, the TEDE for onsite consequences from the continuous release is found to be:

$$
\begin{gathered}
D_{\text {inh vent }}=\left(1.89 \times 10^{-5} \mathrm{~L} / \mathrm{s}\right) \times\left(5.54 \times 10^{-3} \mathrm{~s} / \mathrm{m}^{3}\right) \times \\
\left(3.3 \times 10^{-4} \mathrm{~m}^{3} / \mathrm{s}\right) \times\left(1.8 \times 10^{4} \mathrm{~Sv} / \mathrm{L}\right) \times(12 \mathrm{~h}) \times(3,600 \mathrm{~s} / \mathrm{h}) \\
D_{\text {inh vent }}=2.7 \times 10^{-2} \mathrm{~Sv}(2.7 \mathrm{rem})
\end{gathered}
$$


where:

$$
\begin{aligned}
& Q=V_{\text {release rate }}=1.89 \times 10^{-5} \mathrm{~L} / \mathrm{s} \\
& X / Q^{\prime} \text { (onsite } 12 \text {-hour) }=5.54 \times 10^{-3} \mathrm{~s} / \mathrm{m}^{3} \\
& \mathrm{R}=\text { acute breathing rate }(\text { Van Keuren } 1996)=3.3 \times 10^{-4} \mathrm{~m}^{3} / \mathrm{s} \\
& U^{\prime} D^{\prime}{ }_{\text {mix }- \text { inh }}(\text { Section } 3.4 .2 .1 .2)=1.8 \times 10^{4} \mathrm{SV} / \mathrm{L}
\end{aligned}
$$

\section{Total Onsite Radiological Consequence}

Total onsite consequences ( $D_{\text {onsite }}$ ) for HEPA filter failure due to overpressure is the sum of the puff and the continuous releases. This is found to be:

$$
\begin{gathered}
D_{\text {onsite }}=D_{\text {inh-filter }}+D_{\text {inh vent }} \\
D_{\text {onsite }}=8.8 \times 10^{-5} \mathrm{~Sv}+2.7 \times 10^{-2} \mathrm{sv} \\
D_{\text {onsite }}=2.7 \times 10^{-2} \mathrm{~Sv}(2.7 \mathrm{rem})
\end{gathered}
$$

\subsection{HEPA Filter Failure Due to Over-pressure Toxicological Consequences}

The toxicological consequences for the HEPA filter failure due to overpressure can be found using the method outlined in Section 5.3.1.2 of the TWRS BIO and the assumptions listed in Section 3.4.1.2 of this SARR. The unmitigated, un-prevented HEPA filter failure due to over-pressure accident frequency was determined to be extremely unlikely. The amount of material released from the filter was determined to be $5.62 \times 10^{-3} \mathrm{~L}$ and is a puff type release. The release rate for operation of the ventilation system without filters is $1.89 \mathrm{~m}^{3} / \mathrm{s}(4,000 \mathrm{scfm})$ and is a continuous type release.

\section{A. HEPA Filter Failure Due to Over-pressure Toxicological Consequences Due to a Puff Release}

As with the radiological source term, the type of material accumulating on Tank 24l-AZ-101 filters is from liquids being deposited on the filters from normal air flow (Sections 3.4.2.1.2.3 and 3.4.2.1.1).

The consequences for the offsite receptor from a filter failure due to over-pressure unmitigated puff release is:

$$
\begin{gathered}
T_{\text {puff off }}=V_{\text {released }} \times \text { SOF } F_{\text {liq puff off }} \\
T_{\text {puff off }}=\left(5.62 \times 10^{-3} \mathrm{~L}\right) \times\left(2.5 \times 10^{-3} \mathrm{~L}^{-1}\right) \\
T_{\text {puff off }}=1.4 \times 10^{-5}
\end{gathered}
$$

where:

$$
\begin{aligned}
& \text { SOF Liq puff off }=2.5 \times 10^{-3} \mathrm{~L}^{-1}(\text { Table } 3-10) \\
& V_{\text {release }}=5.62 \times 10^{-3} \mathrm{~L} \text { (Section 3.4.2.1.2) }
\end{aligned}
$$


For the onsite receptor, the SOF for an extremely unlikely event are also calculated in the same fashion as for the offsite receptor.

The consequence for the onsite receptor from a filter failure due to over-pressure unmitigated puff release is:

$$
\begin{gathered}
T_{\text {puff on }}=V_{\text {released }} \times \text { SOF liq puff on } \\
T_{\text {puff on }}=\left(5.62 \times 10^{-3} \mathrm{~L}\right) \times\left(6.0 \times 10^{1} \mathrm{~L}^{-1}\right) \\
\mathrm{T}_{\text {puff on }}=3.3 \times 10^{-1}
\end{gathered}
$$

\section{B. HEPA Filter Failure Due to Over-pressure Toxicological Consequences Due to a Continuous Release Following the Filter Failure}

For the continuous release, the SOF for an extremely unlikely event are calculated considering a liquid/sludge mixture source term.

$$
\text { SOF }_{\text {mix cont off }}=\left(f_{1} \times \text { SOF }_{\text {liq cont off }}\right)+\left(f_{2} \times \text { SOF } \text { sol cont off }\right)
$$

where:

$f_{1}=0.96$, volume fraction of 1iquid in Tank 241-AZ-101

(data from TWRS BI0, Appendix B, Table 2-3)

$f_{2}=0.04$, volume fraction of solids in Tank 241-AZ-101

(data from TWRS BI0, Appendix B, Table 2-3)

SOF $F_{\text {iq cont off }}=$ for DST liquids $($ Table $3-10)=6.2 \times 10^{-1} \mathrm{~s} / \mathrm{L}$

SOF $_{\text {sol cont off }}=$ for DST solids $($ Table $3-10)=2.8 \times 10^{\circ} \mathrm{s} / \mathrm{L}$

Using the above formula, the SOF for Tank 241-AZ-101 mixed 1iquids and solids is calculated to be:

$$
\mathrm{SOF}_{\text {mix cont off }}=7.1 \times 10^{-1} \mathrm{~s} / \mathrm{L}
$$

The toxic chemical release from unfiltered operation of the ventilation system is drawn from all four AWF tanks, but the mixer pumps operate only in one tank. Therefore, the SOF for the unfiltered release must be adjusted to represent the aerosols from one mixed tank and three un-mixed tanks.

$$
\begin{aligned}
& \text { SOF }_{\text {mix cont off }}=\left(0.25 \times \mathrm{SOF}_{\text {mix cont off }}\right)+\left(0.75 \times \mathrm{SOF}_{\text {liq cont off }}\right) \\
& \text { SOF }_{\text {mix cont off }}=7.1 \times 10^{-1} \mathrm{~S} / \mathrm{L} \\
& \text { SOF }_{\text {liq cont off }}=\text { for DST liquids }(\text { Table } 3-10)=6.2 \times 10^{-1} \mathrm{~s} / \mathrm{L}
\end{aligned}
$$


The SOF for the aerosols released from unfiltered operation of the ventilation system is calculated to be:

$$
\mathrm{SOF}_{\text {mix cont off }}^{\prime}=6.4 \times 10^{-1} \mathrm{~s} / \mathrm{L}
$$
is:

The consequence for the offsite receptor from the loss of an AWF filter

$$
\begin{gathered}
T_{\text {cont off }}=V_{\text {released }} \times S 0 F^{\prime}{ }_{\text {mix cont off }} \\
T_{\text {cont off }}=\left(1.89 \times 10^{-5} \mathrm{~L} / \mathrm{s}\right) \times\left(6.4 \times 10^{-1} \mathrm{~s} / \mathrm{L}\right) \\
T_{\text {cont off }}=1.2 \times 10^{-5}
\end{gathered}
$$

For the onsite receptor, the SOF for an extremely unlikely event is also calculated in the same fashion as for the offsite receptor for the liquid/sludge mixture.

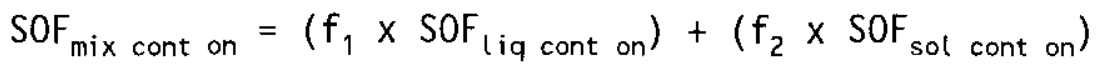

where:

$$
\begin{aligned}
& f_{1}=0.96 \text {, volume fraction of 1iquid in Tank 241-AZ-101 } \\
& \text { (data from TWRS BI0, Appendix B, Table 2-3) } \\
& f_{2}=0.04 \text {, volume fraction of solids in Tank 241-AZ-101 } \\
& \text { (data from TWRS BI0, Appendix B, Table 2-3) } \\
& \text { SOF }_{\text {liq cont on }}=\text { for DST 1iquids }(\text { Table } 3-10)=2.1 \times 10^{2} \mathrm{~s} / \mathrm{L} \\
& \text { SOF }_{\text {sol cont on }}=\text { for DST solids }(\text { Table } 3-10)=6.3 \times 10^{2} \mathrm{~s} / \mathrm{L}
\end{aligned}
$$

Using the above formula, the SOF for Tank 24l-AZ-101 mixed liquids and solids is calculated to be:

$$
\text { SOF }_{\text {mix cont on }}=2.3 \times 10^{2} \mathrm{~s} / \mathrm{L}
$$

The toxic chemical release from unfiltered operation of the ventilation system is drawn from all four AWF tanks, but the mixer pumps operate only in one tank. Therefore, the SOF for the unfiltered release must be adjusted to represent the aerosols from one mixed tank and three un-mixed tanks.

$$
\begin{aligned}
& \text { SOF }_{\text {mix cont on }}=\left(0.25 \times \mathrm{SOF}_{\text {mix cont on }}\right)+\left(0.75 \times \text { SOF }_{\text {(iq cont on }}\right) \\
& \text { SOF }_{\text {mix cont on }}=2.3 \times 10^{2} \mathrm{~s} / \mathrm{L} \\
& \text { SOF }_{\text {liq cont on }}=\text { for DST liquids }(\text { Table } 3-10)=2.1 \times 10^{2} \mathrm{~s} / \mathrm{L}
\end{aligned}
$$

The SOF for the aerosols released from unfiltered operation of the ventilation system is calculated to be:

$$
\mathrm{SOF}_{\text {mix cont on }}^{\prime}=2.2 \times 10^{2} \mathrm{~s} / \mathrm{L}
$$



is:

The consequence for the onsite receptor from the loss of an AWF filter

$$
\begin{gathered}
T_{\text {cont on }}=V_{\text {released }} \times \text { SOF }^{\prime} \text { mix cont on } \\
T_{\text {cont on }}=\left(1.89 \times 10^{-5} \mathrm{~L} / \mathrm{s}\right) \times\left(2.2 \times 10^{2} \mathrm{~s} / \mathrm{L}\right) \\
T_{\text {cont on }}=4.2 \times 10^{-3}
\end{gathered}
$$

\section{Sum of the offsite Toxicological Consequence}

The sum of the offsite puff release toxicological consequence and the offsite continuous release toxicological consequence gives the total offsite toxicological consequence:

$$
\begin{gathered}
T_{\text {total off }}=T_{\text {puff off }}+T_{\text {cont off }} \\
T_{\text {total off }}=1.4 \times 10^{-5}+1.2 \times 10^{-5} \\
T_{\text {total off }}=2.6 \times 10^{-5}
\end{gathered}
$$

\section{Sum of the Onsite Toxicological Consequence}

The sum of the onsite puff release toxicological consequence and the onsite continuous release toxicological consequence gives the total onsite toxicological consequence:

$$
\begin{gathered}
T_{\text {totat on }}=T_{\text {puff on }}+T_{\text {cont on }} \\
T_{\text {total on }}=3.3 \times 10^{-1}+4.2 \times 10^{-3} \\
T_{\text {total on }}=3.3 \times 10^{-1}
\end{gathered}
$$

\subsection{HEPA Filter Failure Due to Over-pressure Accident Comparison to Guidelines}

Table 3-1l shows that both radiological and toxicological consequences of a HEPA filter failure due to over-pressure fall within the risk guidelines for the extremely unlikely frequency category.

Table 3-11 Radiological and Toxicological Consequences of a HEPA Filter Failure Due to Over-Pressure Accident, with Comparison to Risk Guidelines

\begin{tabular}{||c|c|c|c|c||}
\hline \multirow{2}{*}{ RECEPTOR } & \multicolumn{2}{|c|}{ RADIOLOGICAL } & \multicolumn{2}{c|}{ TOXICOLOGICAL } \\
\cline { 2 - 5 } & Consequence & Guide Tine & $\begin{array}{c}\text { Consequence } \\
\text { (SOF) }\end{array}$ & $\begin{array}{c}\text { Guidel ine } \\
\text { (SOF) }\end{array}$ \\
\hline Onsite & $\begin{array}{c}2.7 \times 10^{-2} \mathrm{SV} \\
(2.7 \mathrm{rem})\end{array}$ & $\begin{array}{c}0.1 \mathrm{SV} \\
(10 \mathrm{rem})\end{array}$ & $3.3 \times 10^{-1}$ & 1 (ERPG-3) \\
\hline Offsite & $\begin{array}{c}3.8 \times 10^{-5} \mathrm{~Sv} \\
\left(3.8 \times 10^{-3} \mathrm{rem}\right)\end{array}$ & $\begin{array}{c}0.04 \mathrm{SV} \\
(4 \mathrm{rem})\end{array}$ & $2.6 \times 10^{-5}$ & 1 (ERPG-2) \\
\hline
\end{tabular}




\subsection{HEPA Filter Failure Due to Over-pressure Accident Summary of Safety Class/Safety Significant Structures, Systems, and Components (SSC)s and Technical Safety Requirement (TSR) Controls}

There are no new Safety SSCS required by this project to either the existing AWF ventilation system (241-A-702) or the upgraded ventilation system to be provided by Project $W-030$, associated with preventing or mitigating the consequences of the HEPA filter failure due to over-pressure accident.

The current control (LCO 3.4.3) (Heubach 1996) is still required to ensure the consequences of a HEPA filter failure due to over-pressure accident remain within the risk evaluation guidelines:

- LCO 3.4.3 requires the HEPA filters to be maintained such that the dose rate from them is $<200 \mathrm{mrem} / \mathrm{h}$. This ensures that HEPA filter loadings do not exceed the values assumed in this report.

\subsubsection{Tank Bump Accident}

\subsection{Aging Waste Facility Tank Bump Accident Scenario}

The thermal phenomenon known as a tank bump occurs when steam stored in the waste causes a waste rollover and a rapid steam pressurization of the tank headspace. The Aging Waste Facility Tank Bump Accident Scenario analys is strategy is addressed in Section 5.3.2.22 of the TWRS BI0. A tank bump is a safety concern because of the potential for a release of aerosolized waste to the environment. The following tank bump scenario description, used as a basis for the Tank 24l-AZ-101 mixer pump test analysis, is summarized from Section 5.3.2.22 of the TWRS BI0, Rev 0 .

The initial conditions for a tank bump accident to occur are those leading to local saturation temperature and steam buildup within the waste. Those require:

(1) a heat generation rate greater than 7,600 W(26,000 Btu/h), assuming no active ventilation, to reach waste saturation temperature $104{ }^{\circ} \mathrm{C}$ $\left(220^{\circ} \mathrm{F}\right)$ at atmospheric pressure,

Note: For Tank 241-AZ-101, the saturation temperature would be $126{ }^{\circ} \mathrm{C}\left(258{ }^{\circ} \mathrm{F}\right)$ at the bottom of the tank (accounting for hydrostatic pressure) and $104{ }^{\circ} \mathrm{C}\left(220^{\circ} \mathrm{F}\right)$ at the surface (Sathyanarayana 1994),

(2) an amount of non-convective and highly viscous sludge holding steam bubbles, and

(3) an in-tank waste heat removal system failure.

In addition to this, the higher the waste level is, the higher the saturation temperature and the energy stored before a bump. 


\subsection{Tank bump scenario analysis and controls for Tank 241-AZ-101 mixer pump test}

Tank 241-AZ-101 currently contains waste with a heat generation rate of approximately 70,806 W(241,600 Btu/h) (Hodgson 1995). The operation of the two $300 \mathrm{hp}$ mixer pumps will raise the tank heat generation rate significantly (i.e., by $402,000 \mathrm{~W}[1,374,000 \mathrm{Btu} / \mathrm{h}]$ for a total heat generation rate of $472,806 \mathrm{~W}[1,613,000 \mathrm{Btu} / \mathrm{h}]$ from Nordquist 1997 . This is well above the minimum heat load value that may lead, in certain conditions, to waste saturation temperatures $(7.6 \mathrm{~kW}[26,000 \mathrm{Btu} / \mathrm{h}])$; therefore, 241-AZ-101 is judged to have the conditions necessary for a tank bump.

For the unmitigated and un-prevented accident scenario, it was postulated that the cooling capability of the primary tank active ventilation system for Tank 241-AZ-101 would be lost for an indefinite amount of time. The annulus ventilation system is under repair as of this writing, and is therefore, not available to provide additional cooling for the tank waste. The conservative assumption has been made that this system would not be available during the mixer pump test. This results in a bounding analysis in that, should the annulus system be made available, all safety margins would be increased over analyzed values. Therefore, considering the assumption of the loss of the primary ventilation system, the frequency of a Tank 24l-AZ-101 tank bump with operating mixer pumps was categorized as an "anticipated" event (frequency greater than $10^{-2} / \mathrm{yr}$ ) based on the fact that mixer pump operation introduces an additional heat load large enough to potentially raise the bulk waste temperature above the atmospheric saturation temperature, placing the tank in a potential tank bump situation.

\section{A. Normal operation of the pumps and the primary ventilation system}

In addition to the heat introduced by the operation of the mixer pumps in tank 241-AZ-101, an increase in waste temperature may occur due to changes in heat transfer characteristics within the waste. These changes may result from re-suspension of solid particulates within the liquid waste as well as nonmobilized sludge areas (even with two pumps operating, it has yet to be determined how long it might take before the sludge becomes completely mixed). When the pumps are turned off at the end of the test or during test interruptions, the bottom of the tank could potentially experience a temperature excursion due to reduced thermal conductivity as the waste solids resettle. This effect is expected even with the primary ventilation system operating normally.

The tank bump protection strategy is one of prevention and relies on Air Lift Circulator (ALC) operation to prevent the potential for heat and steam bubble buildup within the sludge. Several tanks during the history of Aging Waste tanks (Bendixsen 1990) have had tank bumps. These tank bump accidents only occurred in "boiling" tanks (from 0.6 to $7 \mathrm{Million} \mathrm{Btu/h}$, and sludge temperatures well above $240^{\circ} \mathrm{F}$ ) prior to ALC full implementation (the cases involved situations in which either no ALCs were operating, only 4 ALCs were operating, or a case in which the ALCS had been stopped and were in the process of being re-started at the time of the bump). In most of the cases, these tanks were not provided with any active cooling ventilation system at the time of the bump. During over 40 years of Hanford Site operation, the ALCs have been the most successful method used to prevent "boiling" tanks from bumping. Several studies have been performed to assess ALC use for tank bump 
prevention. Among these are Fineman 1982, which measured ALC convective flow rates, and Fineman 1984, which contains a Pacific Northwest National Laboratories (PNNL) modelling evaluation of the minimum number of ALCs necessary to prevent tank bumps in ful1-scale, partial tank laboratory experiments. The latter study also included some modelling for in-tank equipment effects on ALC use (no effect was noted). The lack of effect of intank hardware (such as drywells, thermocouples, etc.) on ALC operation can also be seen in photographic evidence (PNL 1979) in which the surface of the liquid waste can clearly be seen to be entirely disturbed by the ALC operation, with no null areas visible. Tank 241-AZ-101 was constructed with 22 ALCs and, using established procedures for ALC use, has never experienced a tank bump. The current AWF Interim Operational Safety Requirements (IOSRs) (Heubach 1996, LCO 3.4.4) require that the ALCS be operated as soon as the temperature reaches $230^{\circ} \mathrm{F}$ for the sludge (or the bottom of the tank) and $200^{\circ} \mathrm{F}$ for the liquid. Thus, the normal operation of the mixer pumps is covered by the current controls and no additional controls are required. This LCO also requires that a minimum number of ALCS be available for operation, should the temperatures exceed the LCO temperature limits for supernatant or sludge. To comply with this portion of the LCO, sludge level monitoring by means of one of the available methods outlined in Chapter 2 will have to be maintained throughout the mixer pump test. Sludge movement caused by the mixer pump operation may cause sludge buildup to $64 \mathrm{~cm}(25-i n$.$) under the ALCs$ and plug the draft tubes (see Section 2.4.4.1.1 of Appendix B of the TWRS BIO for details of the ALCs). ALC draft tubes are $76 \mathrm{~cm}(30-i n$.$) above the tank$ bottom. Operation of adjacent ALCs may be necessary (as determined during the test) to remove sludge buildup from around the affected ALC draft tube.

\section{B. Off-normal situations:}

A prolonged and total loss of primary ventilation could result in tank waste conditions conducive to a thermal bump. This scenario is very unlikely given the existing backup ventilation system, as well as the existence of connection ports for hook-up of an alternate exhauster. However, in the case of a total loss of ventilation, the pumps will be turned off in accordance with LCO 3.4.1 which requires waste transfers and additions to stop upon a loss of ventilation in order to prevent further buildup of heat and gases. The tank bump potential arises because the ALCs are interlocked to turn off when the ventilation system is down. In fact, LCO 3.4.1 requires this to be verified immediately upon loss of ventilation to prevent tank overpressurization. LCO 3.4.1 addresses this situation as follows: (1) alternate ventilation is required within 40 hours if ALC operation is not required (i.e., waste temperature below $230^{\circ} \mathrm{F}$ for sludge and $200^{\circ} \mathrm{F}$ for 1 iquid), and (2) alternate ventilation is required within 16 hours if ALC operation is required (i.e., waste temperature above $230^{\circ} \mathrm{F}$ for sludge or above $200^{\circ} \mathrm{F}$ for supernatant).

For these off-normal situations, very conservative scoping thermal calculations (Sathyanarayana 1997) have shown that the time for the waste temperature to increase from maximum estimated initial conditions and reach local saturation is within the AWF IOSR time requirement to provide an alternate source of ventilation. Indeed, the analysis considers the hypothetical case of having half of the area of the tank's sludge (approximately $31.5 \mathrm{~cm}$ [12.5 inches] thick) being non-mobilized during the mixer pump test, and being covered by freshly settled solids from the other 
half of the tank at mixer pump shut-off. This fraction of sludge mobilization results in the maximum postulated thickness of sludge buildup in the nonmobilized zone. This would normally be an additional $15.75 \mathrm{~cm}$ (6.25 inches) of sludge, since it would be distributed over the entire tank area, but an additional conservatism is included that the sludge volume may be increased (or fluffed) by up to a factor of 2 because of the pumping action. This results in an additional $31.5 \mathrm{~cm}$ (12.5 inches) of sludge deposition, for a conservative value of $63 \mathrm{~cm}$ (25 inches) for the scenario. For this scenario, the time for the sludge temperature to increase from a maximum anticipated sludge temperature of $230^{\circ} \mathrm{F}$ to sludge saturation temperature $\left(255^{\circ} \mathrm{F}\right)$ is greater than 53 hours, well in excess of the LCO 3.4.1 requirement (16 hours). (Higher sludge temperatures before accident onset would have resulted in ALC operation, equilibrating sludge temperatures to a value closer to supernatant levels.) Moreover, this 53 hour minimum time needed to reach sludge saturation temperature conservatively assumes an instantaneous settling time for sludge after waste disturbance has ceased (actual settling time is more on the order of several days, based on sludge sample from Tank 241-AZ-101) (Gray et a1. 1993).

In addition to this scoping study, empirical data from previous Tank 241-AZ-101 ALC shutdown testing show no bottom temperature peaks close to waste saturation temperatures (Winkler 1995). The sludge temperature rose $5.2^{\circ} \mathrm{F}$ over 1296 hours (with primary ventilation on and annulus ventilation off). These data lend credence to the assertion that current controls are adequate for the performance of the Tank 241-AZ-101 mixer pump test without the need for additional controls.

\subsection{Tank Bump Offsite and Onsite Radiological and Toxicological Consequences Analysis and Comparison to Risk Guidelines}

The bounding accident analysis in Section 5.3.2.22.3 of the TWRS BIO is consistent with the Tank 241-AZ-101 assumptions. The associated calculations are documented in Board 1996.

The results are presented in Table 3-12 below.

Table 3-12 Tank bump Radiological and Toxicological consequences (Excerpt from Table 5.3.2.22-1 of the TWRS BI0)

\begin{tabular}{||c|c|c|c|c||}
\hline \multirow{2}{*}{ RECEPTOR } & \multicolumn{2}{|c|}{ RADIOLOGICAL } & \multicolumn{2}{c|}{ TOXICOLOGICAL } \\
\cline { 2 - 5 } & Consequence & Guideline & $\begin{array}{c}\text { Consequence } \\
\text { (SOF) }\end{array}$ & $\begin{array}{c}\text { Guidel ine } \\
\text { (SOF) }\end{array}$ \\
\hline Onsite & $\begin{array}{c}2.5 \mathrm{SV} \\
(250 \mathrm{rem})\end{array}$ & $\begin{array}{c}5 \times 10^{-2} \mathrm{SV} \\
(5 \mathrm{rem})\end{array}$ & $4.9 \times 10^{3}$ & 1 (ERPG-2) \\
\hline Offsite & $\begin{array}{c}2.2 \times 10^{-3} \mathrm{~Sv} \\
(0.22 \mathrm{rem})\end{array}$ & $\begin{array}{c}5 \times 10^{-3} \mathrm{~Sv} \\
(0.5 \mathrm{rem})\end{array}$ & 0.73 & 1 (ERPG-1) \\
\hline
\end{tabular}


The values of $2.2 \times 10^{-3} \mathrm{~Sv}\left(2.2 \times 10^{-1} \mathrm{rem}\right)$ for the offsite radiological dose meets risk guidelines, but the value of $2.5 \times 10^{0} \mathrm{~Sv}\left(2.5 \times 10^{2} \mathrm{rem}\right)$ for onsite radiological doses exceed the risk guidelines for the unlikely event of an un-prevented, unmitigated AWF tank bump accident analyzed in the TWRS BIO.

The offsite toxicological value is below one and is within the risk guidelines. The onsite toxicological dose is above one and exceeds the risk guidelines for an un-prevented, unmitigated tank bump accident.

Because the unmitigated, un-prevented accident frequency for tank bump during the mixer pump test is "anticipated", offsite radiological guidelines $(0.1$ rem) as well as onsite guidelines are not met. Therefore, the safety control and prevention strategy regarding the tank bump accident is to rely on the current LCO 3.4.4 for ALC operation (Heubach 1996). This LCO provides an enveloping set of controls covering the behavior of the waste during and after the mixer pump test, as well as the heat load additions from the pumps and waste mobilization effectiveness. This LCO permits a reduction in the frequency of the scenario to unlikely, the same as in the TWRS BIO analysis.

Given several uncertainties with respect to the heat load brought to the waste by the pumps and the waste mobilization effectiveness of the pumps (i.e., amount of sludge initially mobilized and time necessary to achieve maximum waste mobilization), the safety control strategy is to; (1) maintain operation of the primary ventilation system, (2) monitor the waste temperatures, and, (3) maintain availability of the ALCs to prevent steam bubble formation when the sludge temperatures reach $230{ }^{\circ} \mathrm{F}$ (in the bottom region of the tank after the pumps are turned off, or in non-mobilized areas).

Loss of ventilation is an anticipated event, but for tank heat-up to occur, the ventilation outage must be for an extended period of time. Such extended outages are unlikely, as discussed in Section 5.3.2.22 of the TWRS BI0, since they are driven by the likelihood of the design basis seismic event $\left(1 \times 10^{-3} / \mathrm{yr}\right)$. Also, in Section 9.3 .3 of Squires 1987 , the frequency of loss of the ALC system is also given as $1 \times 10^{-3} / \mathrm{yr}$. With this frequency reduction, the risk is the same as that of the TWRS BIO analysis, and no further analysis is required.

\section{4.2.2.4 Tank Bump Accident Summary of Safety Class/Safety Significant SSCs and TSR Controls}

The safety SSCS associated with this accident are the ALCs, which prevent steam accumulation and rollover occurrences.

The following existing controls are preventive measures against the AWF tank bump:

- Monitor waste temperature and operate ALCs when the sludge temperature reaches $230^{\circ} \mathrm{F}$ and/or the liquid temperature reaches $200^{\circ} \mathrm{F}$ (LCO 3.4.4); 
- Upon total loss of the ventilation system (primary plus backup systems), turn off the mixer pump(s) to control heat addition to the tank and potential tank over-pressurization and comply with requirements of LCO 3.4.1 and LCO 3.3.2. Also, because ALCS are interlocked to shut off upon loss of ventilation (with verification of the interlock function a requirement of LCO 3.4.1), the ALCS would no longer be available, necessitating the stopping of the mixer pumps. Implementation of an alternate ventilation system is still required, as specified in LCO 3.4.1, within 40 hours if ALCS are not required, or within 16 hours if ALCs are required.

\subsubsection{Breach of Containment}

The following mechanisms (i.e., flammable gas deflagration, dropped equipment, internal missiles, erosion, and material degradation due to high temperatures) due to mixer pump operation result in scenarios already discussed in Squires 1987 and the TWRS BIO. Therefore, no additional consequence calculations were performed.

\subsection{Flammable Gas Deflagration}

This section discusses the hazards and controls associated with the generation, accumulation, storage, release, and postulated combustion of flammable gases in the tank headspace. This hazard was first identified as an Unreviewed Safety Question (USQ) in 1990. This USQ was updated on November 1, 1996 (Serrano 1996) to account for increased understanding of the nature of the hazard and the affected facilities. The updated USQ addresses potential flammable gas hazards in the AWF tanks. The flammable gas USQ remains open for the AWF (Serrano 1996) as of this writing.

On November 1, 1996, RL issued authorization for continued operation of the Hanford Tank Farms (Wagoner 1996) for an interim period, until approval of a Justification for Continued Operation. This SARR affirms the applicability of the RL approved controls for the mixer pump test (Wicks et al. 1997). This affirmation is required for two reasons. First, the initiation of the mixer pump test has the potential to release any flammable gas that has accumulated in the waste matrix and is trapped beneath the waste surface. Second, operation of the mixer pumps will increase waste temperature and will, therefore, increase the rate of flammable gas generation. This results in an increase in the chronic (or "steady state") gas release rate to the tank vapor space.

Radioactive waste generates hydrogen through the radiolysis of water, thermolytic decomposition of organic compounds, and corrosion of the tank's carbon steel walls. Radiolysis and thermolytic decomposition also generate ammonia. Additional flammable gases (such as methane) and an oxidizer (nitrous oxide) are generated by chemical reactions between various degradation products of organic chemicals originally present in the tank. Volatile or semi-volatile organic chemicals also produce organic vapors.

The gas generated through these processes may be released continually to the tank vapor spaces (historically referred to as steady state flammable gas generation) or be retained by the tank's waste matrix, potentially resulting in an episodic gas release event (GRE). Steady state flammable gas generation 
from radiolysis, chemical decomposition, and corrosion is expected from all of the AWF tanks. With a GRE, gas is retained in the tank's waste matrix untif it is spontaneously released or a release is induced during waste disturbing activities, such as mixer pump operations.

An accident scenario for a representative flammable gas deflagration resulting from a GRE in an AWF tank is provided in the TWRS BI0, Section 5.3.2.14.1. The source terms and consequences associated with this event were developed in Van Vleet 1996b. The representative GRE accident analysis assumes the release and ignition of sufficient trapped gas such that the resulting energy creates unfiltered release paths, but is insufficient to collapse the tank dome. A gas release of this size has never been observed, and is not expected for the current waste contents of Tank 241-AZ-101.

Therefore, the energy associated with the deflagration of such a release is considered bounding for Tank 241-AZ-101 with its current waste contents.

The source term selected for the representative GRE accident analysis is based on the assumption that only the liquid component of the waste would be released by the deflagration event. While likely to be valid for a quiescent initial waste condition, the liquid source term assumption may be questioned for the condition where mixer pump operation mobilizes a significant portion of the waste solids. In this case, it may be argued that some fraction of the release due to a deflagration consists of waste solids. As seen in Van Keuren 1996, the existence of a solids component in the source term would result in an increased radiological dose at the receptor locations. Determination of the fraction of solids that may be entrained in the release is an additional uncertainty associated with this event.

As indicated in the TWRS BIO, the consequence analysis for the representative GRE is not considered bounding. However, at this point in the resolution process of the open USQ, the analysis serves to indicate the need for an Authorization Basis control strategy. As provided in the current authorization basis (Wicks et al. 1997) and propagated into the TWRS BIO, the control strategy is prevention. Controls related to monitoring and ignition sources are assigned to specific facilities and tanks on the basis of observed and estimated gas release behavior. These controls are not specifically derived from GRE consequence analysis, and would not be changed by variations in the magnitude of the calculated consequences presented in the TWRS BIO. For information, the TWRS BIO analys is results are summarized in Table $3-13$, excerpted from Table 5.3.2.14-1 of the TWRS BI0. The detailed discussion of the consequence analysis is provided in Section 5.3.2.14 of the TWRS BIO. 
Table 3-13 Radiological and Toxicological Consequences of a Flammable Gas Deflagration

\begin{tabular}{||c|c|c|c|c||}
\hline \multirow{2}{*}{ RECEPTOR } & \multicolumn{2}{|c|}{ RADIOLOGICAL } & \multicolumn{2}{c||}{ TOXICOLOGICAL } \\
\cline { 2 - 5 } & Consequence & Guidel ine & $\begin{array}{c}\text { Consequence } \\
\text { (SOF) }\end{array}$ & $\begin{array}{c}\text { Guidel ine } \\
\text { (SOF) }\end{array}$ \\
\hline Onsite & $\begin{array}{c}4.4 \times 10^{-2} \mathrm{SV} \\
(4.4 \mathrm{rem})\end{array}$ & $\begin{array}{c}5 \times 10^{-3} \mathrm{~Sv} \\
(0.5 \mathrm{rem})\end{array}$ & $8.2 \times 10^{2}$ & 1 (ERPG-1) \\
\hline Offsite & $\begin{array}{c}4 \times 10^{-5} \mathrm{~Sv} \\
\left(4 \times 10^{-3} \mathrm{rem}\right)\end{array}$ & $\begin{array}{c}1 \times 10^{-3} \mathrm{SV} \\
(0.1 \mathrm{rem})\end{array}$ & 0.7 & 1 (PEL-TWA) \\
\hline
\end{tabular}

The specific monitoring and ignition source controls applicable to the AWF tanks are driven by assignment of the AWF tanks to flammable gas Facility Group 2 (Wicks et al. 1997) and the nature of activities and operations performed in the tanks. The mixer pump test does not alter the assignment of Tank 241-AZ-101 to Facility Group 2. In addition, performance of the test falls within the authorization basis definitions for the nature and location of activities and operations. Therefore, with respect to GRE behavior that may be associated with the mixer pump test, the existing authorization basis monitoring and ignition source controls continue to apply.

Thus, the strategy to prevent or mitigate potential hazards associated with flammable gas in Tank 241-AZ-101 during the performance of the mixer pump test involves implementation of the controls detailed in Wicks et al. 1997. The Wicks et al. 1997 strategy is to expeditiously implement achievable and practical controls to manage postulated flammable gas risks. While doing so, progress towards safety issue resolution and USQ closure will continue to concentrate on remaining uncertainties regarding the quantification of risk and effectiveness of control strategies.

The controls are aimed primarily at prevention of ignition of flammable gas (although certain aspects of the control strategy are mitigative in nature). Provisions for ventilation serve to prevent accumulation of chronically released gases and possibly reduce the time at risk assuming the occurrence of a spontaneous or induced gas release. Flammable gas monitoring requirements serve to validate ventilation effectiveness as well as prevent or halt manned activities when margin of safety is considered to be insufficient (i.e., conditions are such that the flammable gases exist in concentrations greater than $25 \%$ of the lower flammability limit). Ignition controls related to work practices and equipment requirements serve to eliminate, to the greatest extent practical, ignition sources.

This three-pronged control strategy (ventilation, monitoring, and ignition source control) is assumed to be effective in preventing the accumulation of flammable gases where ignition sources may be present or to eliminate ignition sources where flammable gases may potentially be present. This document does not present analysis results which quantitatively demonstrate the effectiveness of these controls to prevent flammable gas deflagrations. Quantitative demonstration of the effectiveness of controls will be accomplished as part of the Flammable Gas USQ closure process. 
Steady State Generation

The performance of the tests associated with running the mixer pumps could potentially affect the steady state generation of flammable gases. Steady state flammable gas generation is dependent on several parameters including decay heat load, waste temperature, organic complexant chemical concentrations, and nitrate/nitrite concentration. Running the mixer pumps will increase the waste temperature, potentially resulting in increased steady state flammable gas generation.

The implementation of the Wicks et al. 1997 control strategy during mixer pump operation in Tank 241-AZ-101 provides ventilation to prevent accumulation resulting from a steady state gas release. However, the safety margin provided by compliance with the ventilation requirements of Wicks et al. 1997 may be decreased as a result of the mixer pump test. This is due to the expected increases in waste temperature resulting from mixer pump heat input as well as a possible reduction in waste heat conduction during a potential fluffed sludge condition (see Section 3.4.2.2.2B) during initial settling following operation of the mixer pumps. The increased waste temperature can result in an increased hydrogen generation rate.

In order to provide some degree of confidence that the ventilation flow and AWF IOSRs for ventilation restoration are adequate to prevent a flammable gas deflagration resulting from the increased hydrogen generation rate, a scoping analysis was performed (Estey 1997). This scoping analysis provides a parametric evaluation that determines, based on various bulk waste temperatures, the minimum ventilation flow required to maintain the flammable gas concentration less than $25 \%$ of the LFL in the mixed vapor space of the tank. This scoping analysis also determines the flammable gas concentration increase transient following a loss of forced ventilation flow.

The scoping analysis incorporates Tank 241-AZ-10l specific data, including total organic carbon (TOC) concentration to conservatively represent the organic complexant concentration and waste volume. Then, the minimum ventilation rate for Tank $241-A Z-101$ is parametrically determined based on the temperature. For temperatures in the range of $220^{\circ} \mathrm{F}$ to $230^{\circ} \mathrm{F}$, which adequately bounds the expected bulk waste saturation temperature, a minimum ventilation flow rate of approximately 15 to $20 \mathrm{scfm}$ is required to maintain the flammable gas concentration less than $25 \%$ of the LFL in the mixed vapor space of the tank. This evaluation provides some confidence in the adequacy of the ventilation system to prevent the steady state accumulation of flammable gas to levels above the LFL since the minimum ventilation flow rate provided by the existing 241-A-702 AWF ventilation system ranges from approximately 400 to $600 \mathrm{scfm}$ and the minimum ventilation flow rate provided by the $W-030$ ventilation system is approximately $100 \mathrm{scfm}$.

The scoping analysis then determined the flammable gas concentration increase transient assuming a loss of forced ventilation. Based on the maximum hydrogen generation rate for the bulk waste at saturation temperature (approximately $220^{\circ} \mathrm{F}$ to $230^{\circ} \mathrm{F}$ ), the amount of time with no forced ventilation flow before the dome space concentration would exceed $25 \%$ of the LFL is approximately 1 day. In addition, the amount of time with no ventilation flow before exceeding the LFL is approximately 5 days. This evaluation provides some confidence in the adequacy of the AWF IOSRs to prevent the steady state accumulation of flammable gas to levels above the LFL 
since ventilation restoration is required within 40 hours when supernatant temperature and sludge temperature are below $200^{\circ} \mathrm{F}$ and $230^{\circ} \mathrm{F}$, respectively, and within 16 hours when temperatures in the supernatant and sludge are above these levels (i.e., when ALC operation is required)(LCO 3.4.4). The increased gas generation rates will be reduced to their prior values after temperatures have re-stabilized to the lower, typical values measured today.

Thus, the implementation of the Wicks et al. 1997 control strategy during mixer pump operation in Tank 24l-AZ-101 in conjunction with the application of the AWF IOSRs provides adequate controls to prevent a flammable gas deflagration as a result of steady state flammable gas generation.

\section{Gas Release Event}

The performance of the mixer pump test could also potentially result in a gas release event (GRE). This test involves running the mixer pumps which is defined as a globally waste disturbing operation (Wicks et al. 1997). Waste disturbing activities represent the primary means of releasing gas retained in the waste matrix resulting in a GRE.

The controls required by Wicks et al. 1997 are graded based on the tank Facility Group assignment and the nature of the operation or activity. The AWF tanks are assigned Facility Group 2 status. However, the assignment of Facility Group 2 is based on consideration for future use of the tanks rather than current waste inventory. This facility assignment means that GRE controls are focused on dome space intrusive and waste intrusive regions during non-waste disturbing or locally waste disturbing operations. Controls are extended to ex-tank intrusive regions during globally waste disturbing operations. This test involves running the mixer pumps which is defined as a globally waste disturbing operation. Therefore, the expanded controls are required during operation of the mixer pumps.

The equipment, materials, and work practices associated with this project were evaluated by the Flammable Gas Equipment Advisory Board (FGEAB) to verify compliance with the Ignition Source Control Sets \#1 and \#2 as detailed in Wicks et al. 1997. The FGEAB evaluation of the equipment, materials, and work practices associated with this project determined that the applicable Ignition Source Control Sets were satisfied in all cases, including the case of carbon steel profile thermocouples and/or transfer pumps swaying in the carbon steel risers (Smet 1997).

Comprehensive compliance with the applicable Ignition Source Control Sets not only minimizes the potential for an ignition source following a steady state gas release, but also minimizes the potential for an ignition source following a GRE. This control implementation provides an additional level of safety in order to prevent a flammable gas deflagration even if a large GRE were to occur. However, a large GRE is not expected to occur during mixer pump operation. These expectations are based on the following information:

- Tank 241-AZ-101 currently contains only a small amount of sludge, approximately 35,000 gallons, which limits the maximum amount of potentially retained gas to small amounts (Hodgson 1995). 
- A conservative scoping analysis indicates that if the sludge in Tank 241-AZ-101 retained and released flammable gas in the same volumetric proportion as did Tank 241-SY-101 (prior to mitigation), then a GRE would be insufficient to cause a well mixed headspace to exceed $25 \%$ of the LFL (Hodgson 1996).

- An evaluation of actual amounts of retained gas using the limited data available indicates that the amounts of retained gas in Tank 241-AZ-101 are very small to non-existent (Hodgson 1996).

- Even though mixer pump operation is defined as globally waste disturbing, the test is performed in phases of increasing expected sludge mobilization. Complete and rapid mobilization of all of the sludge is not expected during the first phases of the test.

- After the sludge has been re-distributed and settled, it should not retain significantly more gas than prior to the test.

In the time period between waste sludge mobilization and complete settling, the sludge volume may be larger than it is currently. That is, it will be less compacted. This may result in an increase in the total amount of retained gas and may alter the retention and release (i.e., GRE) behavior postulated as the basis for the flammable gas controls. GRE behavior in the partially settled sludge is not postulated to be worse than the "small" spontaneous GRE or the "large" induced GRE postulated for Facility Group 2 tanks in Wicks et al. 1997.

Thus, the implementation of the Standing Order 97-0l (Wicks et al. 1997) control strategy during mixer pump operation in Tank 241-AZ-101 provides adequate control to prevent a flammable gas deflagration as a result of a GRE, even though a large GRE is not expected to occur.

\subsection{Dropped Equipment}

Consequences of scenarios for dropped equipment were not analyzed. No equipment is planned to be installed or removed during the test. Structural and fatigue analys is for other in-tank components is contained in Section 2.4.4. If non-safety-related in-tank process equipment is damaged through the use of the mixer pumps, an evaluation will be performed to determine the impact of restarting or continuing with the test.

\subsection{Internal Missile}

The pumps have an installed screen [5 cm (2 in) openings] to keep out items that have the potential for damaging the impeller (Nordquist 1997). Any debris items smaller than the screen openings would pass directly through the pump, and have the potential to exit the pump discharge at approximately 18 $\mathrm{m} / \mathrm{s}(58 \mathrm{ft} / \mathrm{s})$. An assessment has been made, based on qualitative engineering judgement, that these potential missiles could not damage the tank wall or safety-related in-tank equipment. This assessment is based on: (1) the discharge height of the mixer pump from the tank bottom [43 cm (17 in)] is below the level of any safety-related equipment; (2) the pump discharge is horizontal (i.e., does not angle upward); and (3) the tank wa11 is greater than $4.6 \mathrm{~m}(15 \mathrm{ft})$ distant from the discharge points of the pump. This distance, combined with the discharge velocity and the $5 \mathrm{cP}$ 
assumed viscosity of the waste (Nordquist 1997) makes it highly unlikely that any potential missile will retain sufficient energy to impart damage to a 1.3 $\mathrm{cm}(1 / 2$ in) tank wall.

An assessment was performed to determine whether a pump impeller failure (the largest potential missile) would penetrate the pump housing and subsequently penetrate the tank wall. It was determined in LANL 1996 that, at an approximate impeller speed of 1,200 rpm (the maximum pump speed) the resulting fragment could not penetrate the pump casing and therefore, could not impact the tank. It was also concluded in the same analysis that if the entire pump impeller were separated from the shaft and dropped axially downward in the tank, the mass of the impeller would not be large enough to penetrate the tank wall. This conclusion also applies to plumb bobs, and other similar materials that may exist in the tank. The conclusion was reached that the dropping of the impeller could not generate a missile of sufficient mass $[45.4 \mathrm{~kg}(100 \mathrm{lb})]$ to affect the tank's integrity.

\subsection{Erosion}

Smith and Elmore 1992 evaluated the effect of an impinging slurry jet on the corrosion rate of the tank wall and floor. Results of the tests indicate that, because of the action of the mixer pump slurry jets, the mixer pump activity will moderately accelerate corrosion of the tank wall and floor. A time averaged corrosion rate of approximately 4 mils/yr was calculated for the highest jet velocity tested for the Neutralized Current Acid Waste (NCAW) test $[4.6 \mathrm{~m} / \mathrm{s}(15 \mathrm{ft} / \mathrm{s})]$. The maximum total base metal loss for the 150-day NCAW test was approximately $1.6 \mathrm{mils}$. Analysis of the weight loss data from the NCAW test coupons with the oxide layer intact indicates it is likely that a lower corrosion rate of $2.5 \mathrm{mils} / \mathrm{yr}$ or less may occur over the long term during actual waste mixer pump operations. This reduction in the corrosion rate is due to the thickness of the oxide layer within the tank. The tank surfaces are heavily oxidized following fabrication as a result of the stress relief process and since their fabrication the tanks have contained corrosive wastes to further increase the impermeability of the layer.

For the mixer pump test, only 1,300 hours are planned, including many hours at reduced jet velocities. Smith and Elmore 1992 also provides data at 42 days, which is representative of the planned mixer pump test duration. The 42-day results are 1 ess than $17 \%$ of the 150 -day values. Therefore, for the mixer pump test, between 0.27 and $0.68 \mathrm{mils}$ of base metal loss is predicted, depending on which of the above 150-day values is used. For the short duration use of the mixer pumps addressed by this safety analysis, and tank walls in Tank 241-AZ-101 that were constructed to be a minimum of $1.3 \mathrm{~cm}[1 / 2$ inch (500 mil)] thick, the predicted erosion-corrosion of the tank steel is insignificant.

\subsection{Material Degradation due to High Temperatures}

The current AWF IOSRs (Heubach 1996) include a waste temperature limit of $300{ }^{\circ} \mathrm{F}$ at which any heat addition devices should be turned off (LCO 3.2.2) in order to preserve the concrete tank wall integrity from temperature excursions above $350^{\circ} \mathrm{F}(S L 2.2)$. For the off-normal situation in which a total ventilation outage occurs, this requirement is enveloped by the Tank Bump analysis requirement to restart ventilation before reaching the sludge saturation temperature of approximately $260^{\circ} \mathrm{F}$. During normal operation, 
waste temperatures beyond $260{ }^{\circ} \mathrm{F}$ are not predicted because of temperature homogenization within the tank with ALCs or mixer pumps operating (Sathyanarayana 1994). If temperatures approach $300^{\circ} \mathrm{F}$, the mixer pumps wi11 be stopped in accordance with LCO 3.2.2.

\subsection{Tank Dome Collapse Accident due to Overload}

The mixer pump test increases the tank dome load substantially. However, the total of the previous load and the new load placed on the tank by the Project $W-151$ equipment is below the enhanced total load limit permitted by JCO 1995. A structural analysis was performed (Moody 1996) that includes design calculations for the concrete pad, the steel support frame, the extension riser and riser 1 ifting bails, and the $20.7 \mathrm{MPa}\left(3,000 \mathrm{lbf} / \mathrm{in}^{2}\right)$ spray wash piping system. Dead load, live load, jet impingement and seismic loads were considered. The mixer pump and mounting plate are bolted to the support frame that is anchored to a concrete pad. A tank riser extension is provided to connect the existing tank riser with the pump support assembly. The pump support system is designed to prevent the transfer of loads directly from the pump to the riser. Thus, the pump is supported by its own on-grade foundation, and is independent of the buried AZ-101 pits and risers.

The Project $W-151$ Functional Design Criteria (Nordquist 1997) and Supplemental Design Requirements Documents (Kohlman 1993) establish the design basis loads and load combinations by reference to the Hanford Plant Standards Standard Design Criteria (SDC) $4.1^{2}$. SDC 4.1 requires dynamic analysis for Safety $\mathrm{Cl}$ ass 2 systems unless otherwise justified. The mixer pump support assembly and riser extension have been classified as Safety Class 2 (Kidder 1994). (See Chapter 4 of this SARR for a correlation between the previous Hanford Site safety class numbering system and the DOE STD 3009-94 system.) Because of this, the mixer pump support assembly and riser extension were analyzed using a "static equivalent" safety class 2 approach.

The mixer pump support foundation earthquake design loading $(0.25 \mathrm{~g}$ Peak Horizontal Ground Acceleration) complies with SDC 4.1, Rev. 11 for Safety Class systems. A Peak Acceleration factor of $0.25 \mathrm{~g}$ is also applied to the concrete foundation since both of these foundations support the Safety Class 2 riser extension (Kidder 1994). Calculations of the earthquake loads transferred from the 241-AZ-101 mixer pump to the support frame and concrete foundation are included in the directional load combinations (Moody 1996). Since the mixer pump assembly is designated safety class 3 , loading criteria of Conrads 1996 were used to determine the magnitude of load transfer. The acceleration or "g" factors used in the analysis were: (1) Horizontal = $0.675 \mathrm{~g}$ and (2) Vertical $=0.45 \mathrm{~g}$, both in excess of those required for Safety Class 2 components.

The results of the analysis show that a11 components of the support system are structurally adequate to support the mixer pump for both normal service and extreme loading conditions. Therefore, the Tank Dome Collapse accident is classified as being Beyond Extremely Unlikely, and no consequences are calculated.

${ }^{2}$ Hanford Plant Standards Standard Design Criteria (SDC) 4.1 has been replaced by GC-LOAD-01, "Design Loads For Facilities." 


\subsection{Seismic}

The results of the HAZOP study given in Appendix $3 A$ show that the deformation or failure of the mixer pump shaft due to a seismic event is extremely unlikely. Moody 1996 evaluated the mixer pump support assembly, riser extension, concrete pad, steel support frame, riser lift bails, and the $20.7 \mathrm{MPa}\left(3,000 \mathrm{lbf} / \mathrm{in}^{2}\right)$ spray wash piping system. Dead load, live load, jet impingement, and seismic loads are considered in the design calculations.

The 241-AZ-101 mixer pump support assembly, extension riser, and spray wash system structural analysis results show that the pump support and riser configuration are acceptable for the applied design requirements. (See Section 3.4.2.3.6 for an additional seismic discussion.)

A breach of containment caused by the deformation or the failure of the mixer pump shaft due to a seismic event is then Beyond Extremely Unlikely and no consequences are calculated.

During and after a seismic event, the scenario could occur wherein the primary ventilation fails (as described in the TWRS BI0 Section 5.3.2.23.3) either through electrical power outage or ventilation system mechanical failure, but the mixer pumps are left running, either through human error or a situation in which the operator is prevented, for some reason, from stopping the pumps (injury, etc.). In this scenario, the concern would be for the continued addition of pump energies to the tank with a reduced heat removal capability from the tank to raise the waste temperatures to the point where tank bump would become a potential. The risk associated with this scenario, however, is bounded by that of the HEPA filter failure due to over-pressure, discussed in Section 3.4.2.1.2. The frequency the design basis earthquake, from the TWRS BI0, is $1 \times 10^{-3}$. This frequency, combined with the frequency reduction associated with the pump being left running after the seismic event in which the ventilation system is lost (contrary to controls), brings the accident into the extremely unlikely category. The consequences of this accident are bounded by the 24 hour emission calculated for the HEPA failure scenario, since Tank Farms Emergency Response personnel, whose function it is to verify equipment status (in this case, that the mixer pumps are off in accordance with requirements) would have completed their checks well before the 24 hour period. Also, the onset of any potential tank bump will be alleviated by the mixer pump action over that of a quiescent tank. Because of these prevention/mitigation factors, this accident is felt to be adequately bounded, and no further analys is is required.

\subsubsection{Criticality}

The Criticality Safety Evaluation Report (CSER) (Vail 1997) documents an evaluation of the criticality safety implications of the mixer pump test to be performed in Tank 241-AZ-101. The CSER does not identify a scenario associated with the mixing test that could lead to a criticality. It is concluded that testing the mixer pumps will not sufficiently increase the concentration of plutonium in any portion of the waste contained in 241-AZ-101 to pose a criticality safety concern.

Mixing the waste will disperse the plutonium, and none of the mechanisms capable of increasing plutonium concentration appear capable of overcoming the dispersal and blending mechanisms. The calculated k-effective $\left(k_{e f f}\right)$, when 
limited experimental data exist for a similar system and relatively large but reasonable interpolations or extrapolations are necessary, shall not exceed 0.95 (WHC-CM-4-29). For solid tank waste with a conservative composition, as defined in Rogers 1993, the plutonium concentration corresponding to a $k_{\text {eff }}$ of 0.95 is $2.6 \mathrm{~g} / \mathrm{L}$. This concentration of plutonium is known as the subcritical limit with respect to tank waste.

A comparison of the concentration of plutonium in 241-AZ-101 sludge and the subcritical limit is valid when the actual solids are shown to be less reactive than the composition of the conservative waste model (Rogers 1993). The measure of reactivity is determined by comparing the macroscopic absorption cross section of the waste in tank 241-AZ-101 to the macroscopic absorption cross section of the conservative waste model solids. The absorption cross section of the waste based on sample analys is is more than double the cross section of the conservative waste model solids. So, the subcritical limit for the actual waste solids will be higher than $2.6 \mathrm{~g} / \mathrm{L}$ and a correlation between actual and calculated plutonium concentrations in the waste to the subcritical limit is conservative.

Based on waste transfer data reported in Vail 1997, the highest measured plutonium concentrations from sample analysis in the supernate and the sludge of Tank 241-AZ-101 are $0.000019 \mathrm{~g} / \mathrm{L}$ and $0.175 \mathrm{~g} / \mathrm{L}$, respectively, and the highest plutonium concentration in a waste batch transferred into the tank was $0.0242 \mathrm{~g} / \mathrm{L}$. The transfer data also indicates that a very thin layer of solids may reside in the tank with a plutonium concentration of up to $0.63 \mathrm{~g} / \mathrm{L}$. It follows that the sample data and waste transfer data support the conclusion that the margin of criticality safety in the undisturbed solids in the tank ranges from a factor of 4.1 to 14.8. Also, the waste composition based on the sample analysis indicates that the neutron absorbing capacity of the nonfissile constituents is 16 times the amount of absorbers necessary to assure sub-criticality for any plutonium concentration.

The primary criticality safety aspect of mixing the waste solids is whether the plutonium remains intimately associated with the neutron poisons while the solids are suspended, and after settling. The exact mechanism which holds the plutonium in the 24l-AZ-101 solids is not known, but it is reasonable to suggest that many different mechanisms contribute (i.e., precipitation, adsorption, agglomerated solids, etc.). The preferential segregation of $\mathrm{Pu}$ from the other hydroxides is most likely prevented by solid agglomerates containing $\mathrm{Pu}$ at very large absorber-to-Pu ratios. Whyatt et al. 1996 explains that hot-cell settling tests and flocculation calculations lead to the conclusion that particles are flocculated under normal waste tank conditions, and interaction potentials promote a very rapid flocculation rate, even after the agglomerates are broken up by hydraulic forces such as mixer pumps. The investigation into Pu chemistry in waste tank environments does not lead to any scenario which suggests a criticality in the solid phase of the waste is possible.

An evaluation of the criticality safety aspects of mixing the waste in 241-AZ-101 must also investigate the consequences of Pu segregation due to the waste containing discrete particles of $\mathrm{PuO}_{2}$. Serne et a1. 1996 provides "...calculations that show, for the most realistic cases, that the level of segregation of fissiles from neutron absorbers was about a factor of 2.5." This value is the result of particle segregation predictions using the Transient Energy Momentum and Pressure Equations Solutions in Three Dimensions 
(TEMPEST) Fluid Dynamic Model, the Subsurface Transport Over Multiple Phases (STOMP) code (a simplified one-dimensional stagnant settling model), and mixing experiments which assess particle segregation due to size. For a plutonium concentration increase by a factor of 3 due to particle segregation during settling, the highest plutonium concentration for a thin layer is 1.889 $\mathrm{g} \mathrm{Pu} / \mathrm{L}$, which is less than the subcritical limit.

Another angle of investigation includes a determination of the consequences of pulling waste with the highest estimated $\mathrm{Pu}$ concentration into the mixer pump. The expectation is that the waste layer with the calculated $1.889 \mathrm{~g} \mathrm{Pu} / \mathrm{L}$ will mix with layers of lower Pu concentration resulting in an overall lower average, but the conservative approach is an evaluation which assumes that only the high $\mathrm{Pu}$ concentration waste is in the pump. The volume of the mixer pump housing is approximately 134 L (Nordquist 1997). So, at the highest plutonium concentration of $1.889 \mathrm{~g} \mathrm{Pu} / \mathrm{L}$, only $253 \mathrm{~g}$ of plutonium can reside in the pump at any one time. Hence the plutonium concentration is less than the subcritical limit of $2.6 \mathrm{~g} \mathrm{Pu} / \mathrm{L}$ and the total mass of plutonium in the pump is less than the minimum critical mass of plutonium of $520 \mathrm{~g}$.

The scenarios evaluated and the data presented support the conclusion that a large margin of criticality safety exists in waste tank 241-AZ-101 and the mixer pump test will not pose a criticality safety concern. An added layer of conservatism to this conclusion is that allowances for the quantity of ${ }^{240} \mathrm{Pu}$ in plutonium concentrations has not been taken. Plutonium-240 has a substantial neutron capture cross section, and so will decrease the reactivity of the waste.

Because this scenario is considered to be beyond extremely unlikely, no further study is required.

\subsubsection{Beyond Design Basis Accidents}

No BDBAs were evaluated for the mixer pump test. Because the test procedure is of relatively short duration (approximately 1300 hours), the identification and evaluation of BDBAs was judged to be unnecessary. This judgement is consistent with the graded approach implementation of DOE 5480.23 . 


\subsection{SAFETY SYSTEMS, STRUCTURES, AND COMPONENTS}

The safety classifications for the Project $W-151$ systems, structures, and components (SSC)s were determined in Bourger 1993 and are not being redone for this safety document. The highest safety classification assigned is Safety class 2 which is assigned to the mixer pump support system, though this system was analyzed to equivalent Safety Class 1 seismic criteria.

The existing tank farm SSCS remain unchanged except for the airlift circulators. As a result of safety analysis in Chapter 3 , the airlift circulators require a designation change, previously identified as IOSR related equipment (Kidder 1994) but now perform a Safety Class 1 function based on the outcome of the tank bump scenario. However, this equipment (including support and ancillary equipment systems as discussed in Section 2.7.1.5) is currently installed and is not readily replaceable, nor can it be verified in-situ as meeting the requirements for performing the Safety Class 1 function. Therefore, in light of the short duration of the mixer pump test and the availability of spare or backup support systems, the recommendation is made that this equipment be accepted for continued use as a preventive measure against tank bumps during the mixer pump test.

Since all previous analyses have used the former WHC safety classification class 1,2 , and 3 system, the use of the current term "Safety Class" is used interchangeably with Safety Class 1 (SC-1) and "Safety Significant" is used interchangeably with Safety Class 2 (SC-2) and Safety Class $3(\mathrm{SC}-3)$. 
HNF-SD-WM-SARR-042 REV 1

This page intentionally left blank. 


\subsection{DERIVATION OF TECHNICAL SAFETY REQUIREMENTS}

There are no new TSRs associated with the Tank 241-AZ-101 mixer pump test. The existing AWF Interim Operational Safety Requirements (Heubach 1996) apply and prevent the consequences as discussed in Chapter 3.0. Table 5-1 summarizes the preventive or mitigative actions identified for each of the accidents analyzed in Chapter 3.0, and identifies the applicable Interim

Operational Safety Requirement or other control document that implements the required actions. 
Table 5-1 Summary of Preventive/Mitigative Actions

\begin{tabular}{|c|c|c|}
\hline Accident Scenario & Preventive or Mitigative Actions during mixer pump test & $\begin{array}{l}\text { Applicable IOSR or } \\
\text { Other Control } \\
\text { Document }\end{array}$ \\
\hline $\begin{array}{l}\text { Unfiltered release of } \\
\text { radionucl ides and toxic } \\
\text { aerosols from the tank } \\
\text { (Section } 3.4 .2 .1 \text { ) }\end{array}$ & $\begin{array}{l}\text { Limiting the maximum activity on each filter that gives an } \\
\text { Equivalent Dose Rate of } 200 \mathrm{mrem} / \mathrm{h} \text { on contact controls the } \\
\text { amount of particulates that could be expelled. }\end{array}$ & $\begin{array}{l}\text { LCO } 3.4 .3 \\
\text { AHF IOSRS }\end{array}$ \\
\hline $\begin{array}{l}\text { Tank Bump } \\
\text { (Section } 3.4 .2 .2 \text { ) }\end{array}$ & $\begin{array}{l}\text { - LCO } 3.4 .1 \text { requires vent } i \text { lation operability to prevent tank } \\
\text { pressurization and an unfiltered release. Operation of the } \\
\text { vent system also provides a cooling mechanism to remove the } \\
\text { heat input due to mixer pump operation. } \\
\text { sludge movement caused by mixer pump operation may build up } \\
\text { sludge to } 64 \mathrm{~cm} \text { ( } 25-\text { in.) or more under ALCs and tend to plug } \\
\text { them. Adjacent ALCs, as appropriate, will be operated to } \\
\text { remove sludge from around the affected ALC. Sludge buildup } \\
\text { will be monitored during the test to determine when, and which, } \\
\text { ALCs should be started (per Ross 1997). } \\
\text { - Upon loss of the primary ventilation system and backup, the } \\
\text { mixer pump(s) will be turned off to control gas and heat } \\
\text { buildup in the tank. The primary ventilation recovery times } \\
\text { ( } 40 \text { hours when ALCs are not required and } 16 \text { hours when ALCs are } \\
\text { required per LCO } 3.4 .4 \text { ) are unchanged for the mixer pump test. } \\
\text { - During normal operation of the pump(s) and at the end of the } \\
\text { test while the pumps are turned off, the waste temperature will } \\
\text { be monitored and the Air Lift Circulators operated as soon as } \\
\text { the temperature reaches } 230 \text { of for sludge and } 200 \text { of for } \\
\text { liquid. }\end{array}$ & $\begin{array}{l}\text { LCO } 3.4 .1 \\
\text { AWF } \text { IOSRS } \\
\text { LCO } 3.4 .4 \\
\text { AWF } 1 \text { IOSRS } \\
\\
\text { LCO } 3.4 .1 \\
\text { AWF } 10 \text { OSRS } \\
\\
\text { LCO } 3.4 .4 \\
\text { AWF } 10 \text { SRR }\end{array}$ \\
\hline $\begin{array}{l}\text { Breach of Containment } \\
\text { (Section } 3.4 .2 .3 \text { ) }\end{array}$ & $\begin{array}{l}\text { - High temperature (3.4.2.3.5): } \\
\text { - Primary and backup tank exhaust ventilation systems } \\
\text { shall be operable with one system operating. } \\
\text { - The primary tank waste temperature shall be maintained } \\
\leq 300{ }^{\circ} \mathrm{F} \text { and all heat generating equipment (e.9., mixer } \\
\text { pumps) shut off if this temperature is reached } \\
\text { - Flammable gas deflagration (3.4.2.3.1): } \\
\text { - Implementation of I gnition Source Control as well as } \\
\text { monitoring for flammable gas is a prevent ive measure } \\
\text { against deflagration and breach of the tank and } \\
\text { ventilation confinement in the event that an episodic gas } \\
\text { release exceeds } 100 \% \text { of the lower flammability limit. } \\
\text { - Tank dome collapse due to overload ( } 3.4 .2 .3 .6 \text { ): } \\
\text { - This event is deemed beyond extremely unlikely for the } \\
\text { mixer pump test based on analysis of dead load, live } \\
\text { load, jet impingement, and seismic loads. All components } \\
\text { of the support system were found adequate to support the } \\
\text { mixer pumps for both normal service and extreme } \\
\text { conditions. } \\
\text { - Seismic ( } 3.4 .2 .3 .7 \text { ): } \\
\text { pump support and riser configuration are acceptable for } \\
\text { the applied design requirements. }\end{array}$ & $\begin{array}{l}\text { LCO } 3.4 .1 \\
\text { AWF IOSRS } \\
\text { LCO } 3.2 .2 \\
\text { AWF IOSRS } \\
\text { Tank Farms Standing } \\
\text { Order } 97-01 \\
\text { AC } 5.22 \\
\text { AWF IOSRs } \\
\text { Design Feature }\end{array}$ \\
\hline $\begin{array}{l}\text { Criticality } \\
\text { (Section } 3.4 .2 .4 \text { ) }\end{array}$ & $\begin{array}{l}\text { - A Criticality Safety Evaluation Report prepared for Project } \\
\text { W- } 151 \text { identified no scenario associated with the mixer pump } \\
\text { test that could credibly lead to criticality. }\end{array}$ & $\begin{array}{l}\text { AC } 5.12 \\
\text { AHF IOSRs }\end{array}$ \\
\hline
\end{tabular}

$A C=$ Administrative Control.

AWF = Aging Waste Facility.

IOSRS = Interim Operational Safety Requirements.

LCO = Limiting Condition for Operation. 


\subsection{PREVENTION OF INADVERTENT CRITICALITY}

This section contains information relevant to prevention of inadvertent criticality as a result of the installation of the $W-151$ mixer pumps and operation of the mixer pump test. For further information on the Tank Waste Remediation Systems (TWRS) specific criticality safety and protection program, see Section 4.3 of the TWRS BI0. The program ensures that sufficient controls are in place to reduce the likelihood of inadvertent nuclear criticality excursions as a result of the activities performed within the TWRS facilities.

\subsection{REQUIREMENTS}

See Section 4.3 of the TWRS BI0 for requirements.

\subsection{FACILITY IMPLEMENTATION}

See Section 4.3 of the TWRS BIO for facility implementation.

\subsection{PROJECT IMPLEMENTATION}

Vail 1997 evaluates the safety aspects of the mixer pump test. The Criticality Safety Evaluation Report is necessary to address the potential that mixing, suspension, and settling of tank fissile material may result in a criticality safety concern. See Section 3.4.2.4 for further discussion on criticality. 
HNF-SD-WM-SARR-042 REV I

This page intentionally left blank. 


\subsection{RADIATION PROTECTION}

This section identifies the requirements for radiation protection as a result of the installation of the $W-151$ mixer pumps and operation of the mixer pump test.

\subsection{REQUIREMENTS}

See Section 4.4 of the TWRS BI0 for requirements.

\subsection{FACILITY IMPLEMENTATION}

See Section 4.4 of the TWRS BI0 for facility implementation.

\subsection{PROJECT IMPLEMENTATION}

Design of the upgrades necessary for the mixer pump test followed the requirements of Westinghouse Hanford Company Controlled Manual WHC-CM-4-9, Radiological Design, which has since been canceled by Evans 1994. A review of Nordquist 1997 shows that the uncontrolled area dose rate limit of $0.5 \mathrm{mrem}$ from WHC-CM-4-9 was used for the design. This limit is conservative from the standpoint of the upgrades being in a controlled tank farm facility. The current dose rate limit from Evans 1994 for controlled full-time use is $2.5 \mu \mathrm{Sv}(0.25 \mathrm{mrem})$. The only designs impacted by this change are the radiation shields built for the new equipment (mixer pumps and new thermocouples). Access to the top of the mixer pumps is very difficult due to the motor and installed support equipment. Full-time exposure above the thermocouples is not expected either during the normal operations or potential abnormal operations.

There were no project specific requirements related to radiation protection during construction of the project equipment as all work activities were performed per Section 4.4 of the TWRS BIO. 
HNF-SD-WM-SARR-042 REV 1

This page intentionally left blank. 


\subsection{HAZARDOUS MATERIAL PROTECTION}

This section identifies the requirements for hazardous material protection other than radiological hazards for the mixer pump test.

\subsection{REQUIREMENTS}

See Section 4.5 of the TWRS BIO for requirements.

\subsection{FACILITY IMPLEMENTATION}

See Section 4.5 of the TWRS BIO for facility implementation.

\subsection{PROJECT IMPLEMENTATION}

No project-specific requirements related to hazardous material protection were identified for the mixer pump test or for Project $W-151$ construction. 
HNF-SD-WM-SARR-042 REV 1

This page intentionally left blank. 


\subsection{RADIOACTIVE AND HAZARDOUS WASTE MANAGEMENT}

This section lists the requirement documents for the radioactive and hazardous waste management for the mixer pump test.

\subsection{REQUIREMENTS}

See Section 4.6 of the TWRS BI0 for requirements.

\subsection{FACILITY IMPLEMENTATION}

See Section 4.6 of the TWRS BIO for facility implementation.

\subsection{PROJECT IMPLEMENTATION}

No additional requirements relating to radioactive and hazardous waste management were identified for Project $W-151$ or the mixer pump test. The equipment removed from the tank to accomplish the mixer pump test was managed as mixed waste. 
HNF-SD-WM-SARR-042 REV 1

This page intentionally left blank. 


\subsection{INITIAL TESTING, IN-SERVICE SURVEILLANCE, AND MAINTENANCE}

This section identifies the requirements for testing, surveillance, and maintenance for the Project $W-151$ equipment.

\subsection{REQUIREMENTS}

See Section 4.7 of the TWRS BI0 for requirements.

\subsection{FACILITY IMPLEMENTATION}

See Section 4.7 of the TWRS BIO for facility implementation.

\subsection{PROJECT IMPLEMENTATION}

\subsubsection{Initial Testing}

USQD TF-96-1041 verified that the checkout testing of the installed equipment was within the current TWRS Authorization Basis.

\subsubsection{In-Service Surveillance}

The risk from HEPA filter damage caused by dust or moisture overload, and subsequent over-pressure, is reduced by Surveillance Requirement SR 3.4.1.1 (Heubach 1996). This requirement includes HEPA filter operability surveillance by checking the pressure drop across the filters every 12 hours. This pressure drop should not exceed the operability requirement values for the system. Therefore, any trending toward HEPA filter plugging due to mixer pump and/or ALC operation will be detected, and corrective action taken.

\subsubsection{Maintenance}

New preventive maintenance procedures were not required as all of the new equipment are covered by existing maintenance procedures. Specific maintenance items such as periodicity and types of lubricants were itemized by the various vendors and input into the existing maintenance program as identified in Section 4.7 of the TWRS BIO. 


\section{HNF-SD-WM-SARR-042 REV 1}

This page intentionally left blank. 


\subsection{OPERATIONAL SAFETY}

This section identifies requirements for conduct of operations, Aging Waste Facility (AWF) fire protection, and the implementing program documents directly resulting from the installation of the Project $W-151$ mixer pumps and performance of the mixer pump test.

\subsection{REQUIREMENTS}

See Sections $4.8,4.9$, and 4.10 of the TWRS BIO for requirements.

\subsection{FACILITY IMPLEMENTATION}

See Sections $4.8,4.9$, and 4.10 of the TWRS BI0 for facility implementation.

\subsection{PROJECT IMPLEMENTATION}

No project-specific requirements related to operational safety or fire protection were identified for Project $W-151$ or the mixer pump test. Per the requirements of DOE Order 5480.7, no project-specific fire hazards analysis was required. 
HNF-SD-WM-SARR-042 REV 1

This page intentionaliy left blank. 


\subsection{PROCEDURES AND TRAINING}

This section lists the requirements for the procedures and training programs for the mixer pump test.

\subsection{REQUIREMENTS}

See Section 4.11 of the TWRS BIO for requirements.

\subsection{FACILITY IMPLEMENTATION}

See Section 4.11 of the TWRS BI0 for facility implementation.

\subsection{PROJECT IMPLEMENTATION}

There are specific training requirements for operation of the mixer pumps including on-the-job training cards, required reading, and additional certifications for the nuclear power operators for operating the new equipment. These requirements are specified in Bohan 1996.

The procedure to perform the mixer pump test is TF-210-0TP-001 (Ross 1997). 
HNF-SD-WM-SARR-042 REV 1

This page intentionally left blank. 


\subsection{HUMAN FACTORS}

This section 1 ists the requirements for a human factors program to

demonstrate that human factors are considered in facility design where human actions are relied upon for preventive or mitigative actions.

\subsection{REQUIREMENTS}

See Section 4.18 of the TWRS BIO for requirements.

\subsection{FACILITY IMPLEMENTATION}

See Section 4.18 of the TWRS BI0 for facility implementation.

\subsection{PROJECT IMPLEMENTATION}

The application of human factors is graded on project risk, complexity, and level of involvement of the operator at the facility. A human factors systematic inquiry was not required for the mixer pump test. Within TWRS, human factors are considered in the development of procedures and controls, staffing, interface with Safety systems, structures and components, surveillance, maintenance, and Safety Analyses. For the mixer pump test, various human factors were used including development of a written mixer pump test procedure, validation of the procedure, qualification and training of the nuclear power operators, and design of the test monitoring console with design improvement feedback from the operators. Since this is a one-time test, no comparisons were made regarding allocation of mixer pump control functions between the operators versus automatic devices. 
HNF-SD-WM-SARR-042 REV 1

This page intentionally left blank. 


\subsection{QUALITY ASSURANCE}

This section lists the requirements for a quality assurance program to ensure the safety of personnel and the public, for environmental protection, and for the implementing program documents.

\subsection{REQUIREMENTS}

See Section 4.12 of the TWRS BIO for requirements.

\subsection{FACILITY IMPLEMENTATION}

See Section 4.12 of the TWRS BI0 for facility implementation.

\subsection{PROJECT IMPLEMENTATION}

Implementation of specific quality assurance requirements for Project W-151 equipment was controlled by Manthei 1994.

The Quality Assurance Program consists of the following:

- Personnel performing construction on this project were trained and qualified in accordance with the above quality assurance program plan and DOE Order 5480.20A.

- Quality Improvement processes described in the quality assurance programs provided for the detection and correction of quality problems throughout the design and construction of this project.

- Documents associated with this project have been independently reviewed for completeness and accuracy. A record index is available to classify all quality assurance records to aid in document retrieval.

- Work processes associated with this project have been and will be strictly adhered to in accordance with this quality assurance program plan. Appropriate administrative procedures have been developed and approved to control key aspects in the design and construction of this project.

- Designs associated with this project were independently reviewed and approved. Completed construction is accurately depicted by as-built drawings. 
- Procurement of safety-class and safety-significant items for this project were in compliance with this quality assurance program in that such items have been purchased from qualified suppliers where applicable and all stated requirements have been met as verified through independent inspections, tests, and assessments. Al1 required Certified Vendor Information has been received and appropriately indexed and filed to support continuity of service.

- Inspection and testing of items associated with this project met required standards as verified by properly trained and qualified personnel. Records are on file to attest to accuracy and completeness of the inspection and testing.

- Periodic management assessment of this project was established to ensure this project is compliant with this quality assurance program plan and the objectives stated within met required performance objectives.

- Independent assessments were planned, scheduled, and conducted to confirm that project deliverables and service quality are adequate to meet operational objectives. 


\subsection{EMERGENCY PREPAREDNESS PROGRAM}

This section identifies the requirements for the emergency preparedness functions and response at the site of the mixer pump test.

\subsection{REQUIREMENTS}

See Section 4.13 of the TWRS BI0 for requirements.

\subsection{FACILITY IMPLEMENTATION}

See Section 4.13 of the TWRS BIO for facility implementation.

\subsection{PROJECT IMPLEMENTATION}

No project-specific requirements related to emergency preparedness were identified for the mixer pump test. 
HNF-SD-WM-SARR-042 REV 1

This page intentionally left blank. 


\subsection{PROVISIONS FOR DECONTAMINATION AND DECOMMISSIONING}

This section describes provisions that facilitate future decontamination and decommissioning (D\&D) of the facilities.

\subsection{REQUIREMENTS}

See Section 4.14 of the TWRS BI0 for requirements.

\subsection{FACILITY IMPLEMENTATION}

See Section 4.14 of the TWRS BIO for implementation.

\subsection{PROJECT IMPLEMENTATION}

Project $W-151$ provided appropriate containers to effect removal, receipt, transport, and storage or disposal of equipment removed from AWF

Tank 241-AZ-101 before the mixer pump test. Two containers have also been provided for the removal of a failed mixer pump, if required (Nordquist 1997).

At this time removal of the mixer pumps following the mixer pump test is not anticipated. It is expected, following an acceptable test, that the pumps will be used in the future for waste retrieval purposes, supporting the TWRS strategy.

The design of the installed mixer pumps does include provisions for decontamination and decommissioning, such as a spray ring in the extended riser and capability for installing a flexible receiver to provide tank confinement during pump removal. 
HNF-SD-WM-SARR-042 REV 1

This page intentionally left blank. 


\subsection{MANAGEMENT, ORGANIZATION, AND INSTITUTIONAL SAFETY PROVISIONS}

This section provides the requirements specific to this chapter and pertinent to the safety analysis and for the implementing program documents.

\subsection{REQUIREMENTS}

See Section 4.1 of the TWRS BIO for requirements.

\subsection{FACILITY IMPLEMENTATION}

See Section 4.1 of the TWRS BIO for facility implementation.

\subsection{PROJECT IMPLEMENTATION}

No project-specific requirements related to management, organization, and institutional safety provisions were identified for Project $W-151$ or the mixer pump test.

This section specifically refers to the TWRS BIO: Section 4.2 regarding Standards/Requirements Identification Document, Section 4.15 regarding Configuration Management and Control, Section 4.16 regarding 0ccurrence Reporting, and Section 4.17 regarding Unreviewed Safety Questions. 
HNF-SD-WM-SARR-042 REV 1

This page intentionally left blank. 


\subsection{REFERENCES}

\subsection{DOCUMENTS}

Bendixsen 1990, History of Tank Bumps in Aging Waste Tank Farms WHC-SD-WM-TA-021, Rev. 0, Westinghouse Hanford Company.

Board 1996, Tank Bump Consequence Analys is, WHC-SD-WM-CN-043, 1996, Rev. 2, Westinghouse Hanford Company, Richland, Washington.

Bohan 1996, Training and Staffing Plan for Performance of Tank 241-101-AZ Mixer Pump process Test (Project W-151) Internal Memo 77130-96-014, Westinghouse Hanford Company, Richland, Washington (see Appendix 18.A).

Bourger 1993, Tank 241-AZ-101 Waste Retrieval System Preliminary Safety Analysis for Project W-151, WHC-SD-W151-PSAR-001, Westinghouse Hanford Company, Richland, Washington.

Co11ins 1992, Project W-030 Tank Farm Ventilation Upgrade, Heat Exchanger Performance Calculation, CN W-030-010, Rev. 0, Kaiser Engineers Hanford, Richland, Washington.

Conrads 1996, Seismic Design Guide for Safety Class 3 and 4 Equipment at the Hanford Site, WHC-SD-GN-DGS-30006, Rev. 1A, Westinghouse Hanford Company, Richland, Washington.

Cowley 1996, Development of Radiological Concentrations and Unit Liter Doses for TWRS FSAR Radiological Consequence Calculations, WHC-SD-WM-SARR-037, Rev. 0, Westinghouse Hanford Company, Richland, Washington.

Crass 1993, Specification for Waste Mobilization Mixer Pump Project W-151 Tank AZ-101 Waste Retrieval System, WHC-S-0040, Rev. 1, Westinghouse Hanford Company, Richland, Washington.

Crass 1996, Steam Coil Fatigue Analysis, WHC-SD-W151-DA-006, Rev. 0, Lockheed Martin Hanford Company, Richland, Washington.

DOE-EIS-0113, 1987, Final Environmental Impact Statement: Disposal of Hanford Defense High-Level, Transuranic, and Tank Wastes, Hanford Site, Richland, Washington, 5 vols., U.S. Department of Energy, Washington, D.C.

DOE-EIS-0189, 1996, Final Environmental Impact Statement for the Tank Waste Remediation System, Vol. 1, U.S. Department of Energy, Washington, D.C.

Estey 1997, AY/AZ Waste Tank Primary Ventilation Air Flow Requirements for Mitigation of Steady State Flammable Gas Concentrations in the Tank Headspace, HNF-SD-WM-CN-106, Rev. 0, Lockheed Martin Hanford Company, Richland, Washington.

Evans 1994, Radiological Design Guide, WHC-SD-GN-DGS-30011, Rev. 0, Westinghouse Hanford Company, Richland Washington.

Fineman 1982, Modeling of Airlift Circulators, SD-WM-TI-046, Rev. 0, Rockwell Hanford Operations, Richland, Washington. 
Fineman 1984, Aging Waste Tank Air-Lift Circulator Reports, SD-WM-TI-140, Rev. 0, Rockwell Hanford Operations, Richland, Washington.

Gerton 1990, National Environmental Policy Act (NEPA) Memorandum-To-File (MTF) for Project W-E14, 241-AZ-101 Retrieval System Process Test, 90-VPB-021, Westinghouse Hanford Company, Richland, Washington.

Gray et a1. 1993, Characterization of the Second Core Sample of Neutralized Current Acid Waste From Double-Shell Tank 101-AZ, Pacific Northwest Laboratory, Richl and, Washington

Heubach 1996, Aging Waste Tank Interim Operational Safety Requirements, WHC-SD-WM-0SR-004, Rev. 1E, Westinghouse Hanford Company, Richland, Washington.

Hewitt 1996, Tank Farm Health and Safety Plan, WHC-SD-WM-HSP-002, Rev. 2H, Westinghouse Hanford Company, Richland, Washington.

Hodgson 1995, Tank Characterization Report for Double-Shell Tank 241-AZ-101, WHC-SD-WM-ER-410, Rev. 0, Westinghouse Hanford Company, Richland, Washington, October, 1995

Hodgson 1996, Evaluation of Hanford Tank for Trapped Gas, WHC-SD-WM-ER-526, Westinghouse Hanford Company, Richland, Washington.

HSRCM-1 1997, Hanford Site Radiological Control Manual, HSRCM Project, Richland, Washington.

JC0 1995, Justification for Continued Operation, Tank Farm Dome Loading, Letter, John D. Wagoner, RL, to A. L. Trego, WHC, dated January 6, 1995 (TOP:GZM 94-TOP-173).

Julyk 1997, Mixer Pump Jet Static Impingement Loads on Waste Tank Components, WHC-SD-W151-DA-008, Rev. 0, Lockheed Mart in Hanford Company/Numatec Hanford Corporation, Richland, Washington.

Kidder 1994, Aging Waste Facility Interim Safety Equipment List, WHC-SD-WM-SEL-020, Rev. 2, Westinghouse Hanford Company, Rich1 and, Washington.

Kohlman 1993, Supplemental Design Requirements Document, 241-AZ-101 Waste Retrieval System, WHC-SD-W151-SDRD-001, Rev. 0, Westinghouse Hanford Company, Richland, Washington.

LANL 1996, A Safety Assessment for Proposed Pump Mixing Operations to Mitigate Episodic Gas Releases in Tank 241-SY-101: Hanford Site, WHC-SD-WM-SAD-033, Rev. 2A, Los Alamos National Laboratory, Los Alamos, New Mexico.

Ligotke et a1. 1994, Double-Shell Tank Retrieval Technology: Aerosol and Vapor Source Term Produced During Double-Shell Tank Waste Mobilization and Retrieval: Literature Review and Recommendations, (letter report DSTRTP-CY94-003, February 1994), Pacific Northwest Laboratory, Rich1 and, Washington. 
Manthei 1994, Quality Assurance Program Plan for Project W-151, Tank 101-AZ Waste Retrieval System, WHC-SD-W151-QAPP-001, Rev. 2, Westinghouse Hanford Company, Richland, Washington.

Minteer, Carpenter 1993, Safety Classification of the 241-A-701 Compressed Air System, WHC-SD-WM-DA-137, Rev. 0, Westinghouse Hanford Company, Richland, Washington.

Moody 1996, 241-AZ-101 Mixer Pump Support Assembly, Extension Riser and Spray Wash System Structural Analysis, WHC-SD-W151-DA-005, Rev. 0, Westinghouse Hanford Company, Richland, Washington.

Morris 1996, Unreviewed Safety Question Evaluation, Mixer Pump Process Test for Waste in 241-AZ, Aging Waste Double-shell Tank (W-151), USQE TF-94-0266, Rev. 1, Westinghouse Hanford Company, Richland, Washington.

Napier et al. 1988, GENII - The Hanford Environmental Radiation Dosimetry Software System, PNL-6584, Pacific Northwest Laboratory, Richland, Washington.

Nordquist 1996, Vendor Information File Number 22515, Supplement 32, Mixer Pumps Tank 101-AZ (WST-P-701A, WST-P-702A, Spare) by Lawrence Pumps, Inc., Lawrence, Massachusetts.

Nordquist 1997, Tank 101-AZ Waste Retrieval System, WHC-SD-W151-FDC-001, Rev. 4, Numatec Hanford Corporation, Richland, Washington.

PNL 1979, Photograph, "Tank 101-AZ Air Lift Circulators Operating," 86616-5-CN, Pacific Northwest Laboratory, Richland, Washington.

Reed 1996a, Unreviewed Safety Question Determination, Installation of the Mixer Pump into 241-AZ-101, USQD TF-96-0018, Rev. 2, Lockheed Mart in Hanford Company, Richland, Washington.

Reed 1996b, Unreviewed Safety Question Determination, Install and Operate U7trasonic Probes in 241-AZ-101, USQD TF-96-0805, Rev. 0, Lockheed Martin Hanford Company, Richland, Washington.

Rice 1992a, Project W-030, Tank Farm Ventilation Upgrade, Tank Waste Evaporation Calculation, CN W-030-001, Rev. 1, Kaiser Engineers Hanford, Richland, Washington.

Rice 1992b, Project W-030, Tank Farm Ventilation Upgrade, Waste Tank Vapor Conditions Calculation, CN W-030-013, Rev. 0, Kaiser Engineers Hanford, Richland, Washington.

Rogers 1993, An Analytical Model For Evaluating Subcritical Limits For Waste in Hanford Site Storage Tanks, WHC-SD-SQA-CSA-20356, Rev. 0, Westinghouse Hanford Company, Richland, Washington.

Ross 1997, AZ-101 Mixer Pump Operational Test Procedure, 0TP-210-001, Rev. A-0, Lockheed Martin Hanford Company, Richland, Washington. 
Ryan 1996, Releases from Failed HEPA Filters due to Over-pressurization Event, WHC-SD-WM-CN-063, Rev. 2, 1996, Westinghouse Hanford Company, Richland, Washington

Sathyanarayana 1994, Thermal Hydraulic Safety Analysis of Aging Waste Tank 101-AZ, WHC-SD-WM-ER-335, Rev. 0, Westinghouse Hanford Company, Richland, Washington.

Sathyanarayana 1997, Letter, 8C453-97-KS-002, Thermal Analysis in support of W-151 Tank AZ-101 Process Test, May 16, 1997, Numatec Hanford Corporation, Richland, Washington.

SDC 4.1, Standard Arch-Civil Design Criteria, Hanford Plant Standards, Rev. 11, Westinghouse Hanford Company, Richland, Washington.

Serne et a1. 1996, Fluid Dynamic Particulate Segregation, Chemical Processes, and Natural Ore Analog Discussions that Relate to the Potential for Criticality in Hanford Tanks, WHC-SD-WM-TI-757, Rev. 0, Westinghouse Hanford Company, Richland, Washington.

Serrano 1996, Unreviewed Safety Question Determination, Consolidation of Flammable Gas/S7urry Growth Unreviewed Safety Question Issues, USQD TF-96-0433, Rev. 1, Westinghouse Hanford Company, Richland, Washington.

Smet 1997, Flammable Gas Equipment Advisory Board Interpretation/ Recommendation Report FGEAB-97-017 Rev. 1, W-151 Equipment, Lockheed Martin Hanford Company, Richland, Washington.

Smith and Elmore 1992, Corrosion Studies of Carbon Steel Under Impinging Jets of Simulated Slurries of Neutralized Current Acid Waste (NCAW) and Neutralized Cladding Removal Waste (NCRW), PNL-7816, Pacific Northwest Laboratory, Richland, Washington.

Squires 1987, Aging Waste Facility Safety Analysis Report, WHC-SD-HS-SAR-010, Rev. 2, Last Updated by ECN 631307, May, 1996, Westinghouse Hanford Company, Richland, Washington.

Stahl 1997, Hanford Site Tank Farm Facilities Interim Safety Basis, WHC-SD-WMISB-001, Rev. OM, Westinghouse Hanford Company, Richland, Washington.

Symons and Staehr 1996, Mixer Pump Test Plan for Double-Shell Tank 241-AZ-101, WHC-SD-WM-PTP-027, Rev. 2, Westinghouse Hanford Company, Richland, Washington.

Tardiff 1996a, Unreviewed Safety Question Determination, Installation and Removal of Thermocouples and Thermocouple Trees in 241-AZ-101, TF-96-0448, Rev. 0, Lockheed Martin Hanford Company, Richland, Washington.

Tardiff 1996b, Unreviewed Safety Question Determination, Project $W-151$ Checkout and Testing of Installed Equipment, TF-96-1041, Rev. 1, Lockheed Martin Hanford Company, Richland, Washington.

Tiffany 1996, Unreviewed Safety Question Determination, Camera Installation and Operation at 241-AZ-101, TF-96-0461, Rev. 0, Lockheed Mart in Hanford Company, Richland, Washington. 
Vail 1997, CSER 96-014: Criticality Safety Evaluation Report of Project W-151, 241-AZ-101 Retrieval System Process Test, HNF-SD-W151-CSA-001, Rev. 2, Fluor Daniel Hanford, Richland, Washington.

Van Keuren et al. 1996, Toxic Chemical Considerations for Tank Farm Release, WHC-SD-WM-SARR-011, Rev. 2, Westinghouse Hanford Company, Richland, Washington.

Van Keuren 1996, Tank Waste Compositions and Atmospheric Dispersion Coefficients for use in Safety Analysis Consequence Assessments, WHC-SD-WM-SARR-016, Rev. 2, Westinghouse Hanford Company, Richland, Washington.

Van Vleet 1996a, Waste Tank Ventilation System Waste Material Accumulation WHC-SD-WM-CN-054, Rev. 0, Westinghouse Hanford Company, Richland, Washington.

Van Vleet 1996b, Flammable Gas Deflagration Consequence Calculations for the Tank Waste Remediation System Basis for Interim Operation, WHC-SD-WM-CN-055, Rev. 1, Westinghouse Hanford Company, Richland, Washington.

Wagoner 1996, Letter 96-MSD-283, Contract Number DE-AC06-96RL13200; The U. S. Department of Energy (DOE), Richland Operations Office (RL), Definition and Declaration of Flammable Gas Unreviewed Safety Question (USQ), dated

November 1, 1996, J. D. Wagoner, DOE, to H. J. Hatch, Fluor Daniel Hanford.

Wagoner 1997, Letter 97-MSD-211, Contract Number DE-AC06-96RL13200; Approva1 of Key Documents for Addition to the Tank Waste Remediation System (TWRS) Authorization Basis, dated May 30, 1997, J. D. Wagoner, DOE, to H. J. Hatch, Fluor Daniel Hanford.

Waters and Heimberger 1993, Stress Cycles and Forces on In-Tank Components Resulting from Mixer Pump Operation in DST 101-AZ, WHC-SD-W151-ER-001, Rev 0, Westinghouse Hanford Company, Richland, Washington.

WHC 1996a, AZ-101 Mixer Pump Extension Riser/Wash System Installation, drawing H-2-79275, Rev. 3, Westinghouse Hanford Company, Richland, Washington.

WHC 1996b, 241-AZ-101 Mixer Pump Installation, drawing H-2-79252, Rev. 1, Westinghouse Hanford Company, Richland, Washington.

Whyatt et a1., 1996 Potential for Criticality in Hanford Tanks Resulting from Retrieval of Tank Waste, PNL-11034, Pacific Northwest National Laboratory, Richland, Washington.

Wicks et a1. 1997, Tank Farms Standing Order 97-01, Revision 1, Compensatory Actions for Open Discovery Unreviewed Safety Questions (USQS).

Wicks 1997, Project W-151, "Tank 101-AZ Waste Retrieval System", Startup Readiness Assessment Memorandum of Understanding, J. H. Wicks, LMHC, to D. J. Washenfelder, FDH, dated February 18, 1997 (9751380). 
Winkler 1995, Tank 241-AZ-101 Steam Bumping and Settling Process Test Report, WHC-SD-WM-PTR-012, Rev. 0, Westinghouse Hanford Company, Rich1and, Washington

Wong and Waters 1994, Evaluation of AY/AZ Tank Farm Ventilation System During Aging Waste Retrieval Operations, WHC-SD-WM-TI-386, Rev. 0, Westinghouse Hanford Company, Richland, Washington.

\subsection{U.S. DEPARTMENT OF ENERGY ORDERS, STANDARDS, AND HANDBOOKS}

D0E 5480.22, Technical Safety Requirements, U.S. Department of Energy, Washington, D.C.

DOE 5480.23, Nuclear Safety Analysis Reports, Change 1, U.S. Department of Energy, Washington, D.C.

D0E 6430.1A, General Design Criteria, U.S. Department of Energy, Washington, D.C.

DOE-STD-1027-92, Hazard Categorization and Accident Analysis Techniques for Compliance with DOE Order 5480.23, Nuclear Safety Analysis Reports, U.S. Department of Energy, Washington, D.C.

DOE-STD-3009-94, Preparation Guide for U.S. Department of Energy Nonreactor Nuclear Facility Safety Analysis Reports, U.S. Department of Energy, Washington, D.C.

DOE-STD-3011-94, Guidance for Preparation of DOE 5480.22 (TSR) and DOE 5480.23 (SAR) Implementation Plans, November 1994, U.S. Department of Energy, Washington, D.C.

\subsection{U.S. ENVIRONMENTAL PROTECTION AGENCY}

EPA 1988, EPA-5201/1-88-020, 1988, Federal Guidance Report No. 11, "Limiting Values of Radionuclide Intake and Air Concentration and Dose Conversion Factors for Inhalation, Submersion, and Ingestion," U.S. Environmental Protection Agency, Office of Radiological Programs, Washington, D.C.

\subsection{WESTINGHOUSE HANFORD COMPANY CONTROLLED MANUALS}

WHC-CM-4-29, Nuclear Criticality Safety Manual, Westinghouse Hanford Company, Richland, Washington.

\subsection{NUCLEAR REGULATORY COMMISSION}

NRC 1982, Atmospheric Dispersion Models for Potential Accident Consequence Assessments at Nuclear Power Plants, NRC Regulatory Guide 1.145, 
HNF-SD-WM-SARR-042 REV 1

APPENDIX $3 A$

HAZARDS AND OPERABILITY STUDY

FOR PROJECT W-151 
HNF-SD-WM-SARR-042 REV 1

This page intentionally left blank. 


\subsection{INTRODUCTION}

Project $W-151$ has been established for the purpose of the installation and process testing of two 300 horsepower Mixer Pumps weighing $12,247 \mathrm{~kg}$ $(27,000)$ each in Aging Waste Facility (AWF) Waste Tank 241-AZ-101. The mixer pumps are intended to mix $90 \%$ of the sludge with the supernate in the tank. TWRS SAR Engineering will have the primary role in performing the hazards and accident analysis for the Safety Evaluation. The Safety Evaluation is scheduled to be completed in fiscal year 1996 .

The first step in performing an accident analysis is to identify and qualitatively assess the facility hazards. The results of the assessment are used to determine which abnormal events could initiate accidents with the potential to expose site personnel or the general public to radioactive or chemical hazards.

A number of systematic techniques for hazards identification are available. The technique chosen for Project $W-151$ hazards identification was the Hazards and Operability (HAZOP) Study. The HAZOP methodology is specifically designed for chemical processing and storage areas. It is one of the most exhaustive techniques available because it is designed to examine process deviations in exhaustive detail, and also because it uses a multidisciplinary team of knowledgeable individuals in a systematic brainstorming effort. The HAZOP results are being used as a scoping tool to determine which potential accident sequences must be analyzed in detail in order to demonstrate that the mixer pumps and ancillary equipment in AWF Waste Tank 241-AZ-101 can be safely operated following installation.

\subsection{SCOPE}

The HAZOP identifies equipment and facilities shown on configuration drawings and diagrams within the scope of Project $W-151$ which could contain quantities of hazardous (radiologically hazardous or toxic) materials with a potential to cause significant consequences to the site personnel or the general public. Areas with limited potential to cause consequences outside of the facility boundaries or initiate significant events in other tanks within the tank farms were not included in the scope of the HAZOP.

\subsection{ORGANIZATIONAL RESPONSIBILITIES}

The HAZOP was performed using personnel from Westinghouse Safety Analysis and Nuclear Engineering, DST Retrieval Construction Projects, and other groups essential to the $W-151$ Project. Safety Analysis and Nuclear Engineering coordinated the effort by providing methodology, facilitation, recording, and HAZOP tables (Attachment 1 of Appendix 3A) and HAZOP Report development and editing. DST Retrieval Construction Projects produced the initial draft of the HAZOP tables from raw notes. Other groups included and represented in the HAZOP effort are TWRS Quality Assurance and TWRS Engineering. 


\subsection{METHODOLOGY}

The HAZOP documents the effects of deviations from the design intent of the various "process" parameters. Flow diagrams were used to break the system into nodes. Each major piece of equipment involved in the process is a node, and the piping and/or instrument lines connecting the equipment are also nodes. Pertinent process parameters (guide words) such as flow, pressure, level, and temperature are chosen, and a series of questions are asked about each parameter. Each "question" concerns an abnormal condition of the parameter (for example, "no flow"). The HAZOP team, based on design knowledge and operational experience, postulates the cause(s) and effects of the abnormal process condition. From this information, a qualitative estimate of the consequences of the abnormal condition is obtained. The estimate is then used as a screening tool to determine the need for further analysis.

The product of the HAZOP study is a series of tables (Attachment 1 of Appendix $3 \mathrm{~A}$ ) showing the results. The results are further categorized to include a list of potential abnormal conditions which might cause consequences in the various categories, which is used to prepare a list of accidents to be considered for further analysis.

\subsection{RESULTS}

The summary of results of the HAZOP is included in this section.

The results of the HAZOP analyses were a number of postulated abnormal events which were ranked with respect to severity and frequency of occurrence. Table 3A-1 shows the number of events considered to have potential consequences in each category, for each study node. Note that the number of ranked abnormal events does not have a one-to-one correlation with the node deviations. In some cases, deviations of a parameter associated with one node would cause another deviation of a parameter associated with a second node. (For example, high flow through a line node might cause high level in the destination vesse7.) In some cases the cause and consequences of a particutar deviation at a node are identical to a deviation at another node. These are cross referenced in the HAZOP tables and not generally included in the count as separate ranked abnormal events.

Table 3A-1 shows a summary of the consequence severity and probability of occurrence categories for the energy source/hazard potentials shown in the HAZOP study tables. Table 3A-2 provides a description of the occurrence severity indices and Table 3A-3 a description of the indices for frequencies of occurrence. Only those abnormal events having a potential severity consequence of I or II and a probability range $>1.0 \times 10^{-6}$ will be considered for detailed analysis. 
Table 3A-1. Summary of HAZOP Study Consequence Severity and Frequency of Occurrence Indices. (2 sheets)

\begin{tabular}{|c|c|c|c|}
\hline Equipment/system & Severity & Frequency & No. of Events \\
\hline \multirow{6}{*}{$\begin{array}{l}\text { Inlet to Existing Ventilation System } \\
\text { Node } 1\end{array}$} & s2 & F3 & 1 \\
\hline & s1 & $\mathrm{F} 3$ & 1 \\
\hline & so & F3 & 4 \\
\hline & s1 & F2 & 1 \\
\hline & s2 & $\mathbf{F} 1$ & 1 \\
\hline & s1 & F1 & 2 \\
\hline \multirow{7}{*}{$\begin{array}{l}\text { Inlet to New Ventilation System } \\
\text { Node } 2\end{array}$} & s1 & $\mathrm{F3}$ & 4 \\
\hline & so & F3 & 7 \\
\hline & s2 & $\mathrm{F} 2$ & 2 \\
\hline & $s \uparrow$ & $\mathrm{F} 2$ & 1 \\
\hline & so & $\mathrm{F} 2$ & 1 \\
\hline & s2 & F1 & 1 \\
\hline & s1 & F1 & 2 \\
\hline \multirow{10}{*}{$\begin{array}{l}\text { Waste Tank } \\
\text { Node } 3\end{array}$} & s1 & F3 & 6 \\
\hline & so & F3 & 6 \\
\hline & $\$ 2$ & F2 & 8 \\
\hline & s1 & $\mathrm{F} 2$ & 2 \\
\hline & so & F2 & 1 \\
\hline & s2 & $\mathrm{Fi}$ & 6 \\
\hline & so & F1 & 2 \\
\hline & s3 & FO & 1 \\
\hline & s1 & FO & 4 \\
\hline & so & Fo & 1 \\
\hline \multirow{3}{*}{$\begin{array}{l}\text { Old Exhaust Ventilation System } \\
\text { Node } 4\end{array}$} & $\$ 2$ & F3 & 6 \\
\hline & s1 & F3 & 1 \\
\hline & s2 & $F 2$ & 3 \\
\hline
\end{tabular}


Table 3A-1. Summary of HAZOP Study Consequence Severity and Frequency of Occurrence Indices. (2 sheets)

\begin{tabular}{|c|c|c|c|}
\hline Equipment/system & Severity & Frequency & No. of Events \\
\hline \multirow{4}{*}{$\begin{array}{l}\text { Old Exhaust Ventilation System } \\
\text { Node } 4\end{array}$} & s3 & F1 & 1 \\
\hline & $s 2$ & F1 & 2 \\
\hline & s1 & F1 & 2 \\
\hline & s2 & FO & 1 \\
\hline \multirow{6}{*}{$\begin{array}{l}\text { New Exhaust Ventilation system } \\
\text { Node } 5\end{array}$} & $\mathrm{~S} 2$ & F3 & 5 \\
\hline & s1 & F3 & 3 \\
\hline & so & F3 & 1 \\
\hline & $\$ 2$ & $\mathrm{~F} 2$ & 3 \\
\hline & s2 & F1 & 3 \\
\hline & s1 & F1 & 1 \\
\hline \multirow{4}{*}{$\begin{array}{l}\text { Mixing Pumps } \\
\text { Node } 6\end{array}$} & s1 & F3 & 3 \\
\hline & so & F3 & 6 \\
\hline & so & F2 & 2 \\
\hline & so & F1 & 1 \\
\hline \multirow{3}{*}{$\begin{array}{l}\text { Equipment Installation and Removal } \\
\text { Node } 7\end{array}$} & s2 & F3 & 4 \\
\hline & s! & F3 & 6 \\
\hline & s2 & FO & 1 \\
\hline
\end{tabular}

Table 3A-2. Event Severity Index.

\begin{tabular}{|c|l|}
\hline $\begin{array}{c}\text { Safety class } \\
\text { category } \\
\text { designation }\end{array}$ & \multicolumn{1}{|c|}{ Description } \\
\hline S3 & $\begin{array}{l}\text { Potential significant radiological dose consequences or } \\
\text { chemical exposure to the offsite receptor. }\end{array}$ \\
\hline S2 & $\begin{array}{l}\text { Potential significant radiological dose consequences or } \\
\text { chemical exposure to the onsite co-located worker. }\end{array}$ \\
\hline S1 & $\begin{array}{l}\text { Potential industrial injury, radiological dose consequences } \\
\text { or chemical exposure to the facility worker. }\end{array}$ \\
\hline S0 & $\begin{array}{l}\text { No effect outside the facility confinement systems and no } \\
\text { safety concerns for the facility worker, the onsite worker, } \\
\text { or members of the general public. }\end{array}$ \\
\hline
\end{tabular}


Table 3A-3. Event Frequency Index.

\begin{tabular}{|c|c|l|}
\hline $\begin{array}{c}\text { Frequency } \\
\text { category } \\
\text { designation }\end{array}$ & \multicolumn{1}{|c|}{ Numeric definition } & \multicolumn{1}{|c|}{ Word definition } \\
\hline F3 & $>10^{-2} /$ year & Anticipated \\
\hline F2 & $>10^{-4}$ to $\leq 10^{-2} /$ year & Unlikely \\
\hline Fl & $>10^{-6}$ to $\leq 10^{-4} /$ year & Extremely unlikely \\
\hline F0 & $\leq 10^{-6} /$ year & Beyond extremely unlikely \\
\hline
\end{tabular}

The HAZOP tables are included in Attachment 1 of Appendix $3 \mathrm{~A}$. Abnorma events identified in Table $3 \mathrm{~A}-1$ as having a frequency $>1 \times 10^{-6} / \mathrm{yr}$ and industrial events with risks to hazards commonly accepted in industry are excluded from the events having potential unacceptable safety risk summarized here.

\subsection{NODE 1 - INLET TO EXISTING VENTILATION SYSTEM}

F3 - S2

1. Potential exposure of onsite individual to airborne radionuclides and toxins when filters fail due to tank over-pressure resulting when exhauster fails.

$\mathrm{F} 2-\mathrm{S} 1$

1. Potential exposure of occupational individual to airborne radionuclides and toxins when filters fail due to tank over-pressure resulting when a riser in another tank connected to the AWF ventilation system is opened.

$\mathrm{F} 2-\mathrm{S} 1$

1. Potential exposure of occupational individual to airborne radionuclides and toxins when ventilation ducting fails due to seismic event, high wind, or impact by construction equipment.

$F 1-S 2$

1. Potential exposure of onsite individual to airborne radionuclides and toxins when a chemical reaction results in igniting tank head space flammable gases creating pressure that fails filters causing unfiltered release.

$\mathrm{F} 1-\mathrm{S} 1$

1. Potential exposure of occupational individual to airborne radionuclides and toxins when high wind causes reversal of air flow through open riser on tank. 


\subsection{NODE 2 - INLET TO NEW VENTILATION SYSTEM}

\section{F3 - S1}

1. Potential exposure of occupational individual to airborne radionuclides and toxins when valve in exhaust duct remains closed allowing pressure to build up, exhaust duct valve then opens pressurizing filters causing them to fail, which results in an unfiltered release.

2. Potential exposure of occupational individual to airborne radionuclides and toxins when filters fail due to tank over-pressure resulting when exhauster fails.

3. Potential exposure of occupational individual to airborne radionuclides and toxins when filters fail due to tank over-pressure resulting when a riser in another tank connected to the AWF ventilation system is opened.

\section{F2 - S2}

1. Potential exposure of onsite individual to airborne radionuclides and toxins when ignition of tank head space flammable gases and resulting pressure and heat fail filters causing unfiltered release.

F2 - S1

1. Potential exposure of occupational individual to airborne radionuclides and toxins when ventilation ducting fails due to seismic event, high wind, or impact by construction equipment.

$\mathrm{F} 1-\mathrm{S} 2$

1. Potential exposure of onsite individual to airborne radionuclides and toxins when a chemical reaction results in igniting tank head space flammable gases and resulting pressure fails filters causing unfiltered release.

$\mathrm{F} 1-\mathrm{S} 1$

1. Potential exposure of occupational individual to airborne radionuclides and toxins when high wind causes reversal of air flow through open riser or collapsed stack on tank. 


\subsection{NODE 3 - WASTE TANK}

\section{F3 - S1}

1. Potential exposure of occupational individual to airborne radionuclides and toxins when filters fail due to tank over-pressure resulting when exhauster fails.

2. Potential exposure of occupational individual to airborne radionuclides and toxins when filters fail due to tank over-pressure resulting when a riser in another tank connected to the AWF ventilation system is opened.

3. Potential exposure of occupational individual to airborne radionuclides and toxins when filters fail due to tank over-pressure resulting when a mixer pump is started and mixing action creates a change in the vapor space composition and pressure.

4. Potential exposure of occupational individual to airborne radionuclides and toxins when ignition of tank head space flammable gases created by heat input from mixer pump results in pressure and heat that fail filters causing unfiltered release.

F2 - S2

1. Potential exposure of onsite individual to airborne radionuclides and toxins when ignition of tank head space flammable gases results in pressure and heat that fail filters causing unfiltered release.

2. Potential exposure of onsite individual to radionuclides and toxins when ignition of tank head space flammable gases results in pressure and heat that breach the tank allowing exposure of the soil column to tank contents.

3. Potential exposure of onsite individual to airborne radionuclides and toxins and contamination when ignition of tank head space flammable gases result in pressurizing contaminants through piping leading from tank farm pits when subsequent work is performed in the pits.

$F 2-S 1$

1. Potential exposure of occupational individual to airborne radionuclides and toxins when filters fail due to tank over-pressure resulting when a mixer pump is started and mixing/chemical action creates a change in the vapor space composition and pressure.

$F 1-S 2$

1. Potential exposure of onsite individual to radionuclides and toxins when tank containment is breached and tank contents are leaked to the soil column due to impact by dropped equipment during installation or removal operations. 
2. Potential exposure of onsite individual to radionuclides and toxins when tank containment is breached and tank contents are leaked to the soil column due to impact by a missile ejected by a mixer pump.

3. Potential exposure of onsite individual to radionuclides and toxins when tank containment is breached and tank contents are leaked to the soil column due to erosion by mixer pump action.

4. Potential exposure of onsite individual to airborne radionuclides and toxins when filters fail due to tank over-pressure resulting when a mixer pump is started and mixing/chemical action creates a change in the vapor space composition and pressure.

5. Potential exposure of onsite individual to airborne radionuclides and toxins when filters fail due to tank over-pressure resulting when a mixer pump is started, rearranging tank material which results in critical mass formation and criticality.

\subsection{NODE 4 - OLD EXHAUST VENTILATION SYSTEM}

$F 3-S 2$

1. Potential exposure of onsite individual to airborne radionuclides and toxins when valve in exhaust duct remains closed, loss of power to exhaust fan or exhaust fan failure allows pressure to build up, then the exhaust duct valve opens pressurizing filters causing them to fail which results in an unfiltered release.

2. Potential exposure of onsite individual to airborne radionuclides and toxins when valve in exhaust duct remains closed allowing flammable gases to build up. Ignition of gases creates ventilation system over-pressure causing filters to fail which results in an unfiltered release.

3. Potential exposure of onsite individual to airborne radionuclides and toxins when valve in exhaust duct remains closed causing diminished cooling which results in tank heating causing a tank bump. Sudden release of gases creates ventilation system over-pressure causing filters to fail which results in an unfiltered release.

F3 - S1

1. Potential exposure of occupational individual to airborne radionuclides and toxins when filters fail due to tank over-pressure resulting when a riser in another tank connected to the AWF ventilation system is opened.

$\mathrm{F} 2-\mathrm{S} 2$

1. Potential exposure of onsite individual to airborne radionuclides and toxins when filters fail due to tank over-pressure resulting when filters plug with particulate. 
$F 1-S 3$

1. Potential exposure of offsite individual to airborne radionuclides and toxins when ventilation ducting is breached due to high wind/tornado.

F1 - S2

1. Potential exposure of onsite individual to airborne radionuclides and toxins when ventilation ducting is breached due to Seismic event.

$F 1-S 1$

1. Potential exposure of occupational individual to airborne radionuclides and toxins when filters fail due to tank over-pressure resulting when a riser in another tank connected to the AWF ventilation system is opened.

\subsection{NODE 5 - NEW EXHAUST VENTILATION SYSTEM}

F3 - S2

1. Potential exposure of onsite individual to airborne radionuclides and toxins when valve in exhaust duct remains closed, loss of power to exhaust fan or exhaust fan failure allows pressure to build up, then the exhaust duct valve opens pressurizing filters causing them to fail which results in an unfiltered release.

2. Potential exposure of onsite individual to airborne radionuclides and toxins when valve in exhaust duct remains closed allowing flammable gases to build up. Ignition of gases creates ventilation system over- pressure causing filters to fail which results in an unfiltered release.

3. Potential exposure of onsite individual to airborne radionuclides and toxins when valve in exhaust duct remains closed causing diminished cooling which results in tank heating causing a tank bump. Sudden release of gases creates ventilation system over-pressure causing filters to fail which results in an unfiltered release.

F3 - S1

1. Potential exposure of occupational individual to airborne radionuclides and toxins when filters fail due to tank over-pressure resulting when fan control allows it to over-speed.

2. Potential exposure of occupational individual to airborne radionuclides and toxins when filters fail due to tank over-pressure resulting when a riser in another tank connected to the AWF ventilation system is opened.

$F 2-S 2$

1. Potential exposure of onsite individual to airborne radionuclides and toxins when filter fails due to tank over-pressure resulting when filters plug with particulate. 
2. Potential exposure of onsite individual to airborne radionuclides and toxins when ignition of tank head space flammable gases created by plugged filter results in pressure and heat that fail filters causing unfiltered release.

3. Potential exposure of occupational individual to airborne radionuclides and toxins when ventilation ducting fails due to impact by construction equipment.

$F 1-S 2$

1. Potential exposure of onsite individual to airborne radionuclides and toxins when ventilation ducting is breached due to seismic event.

2. Potential exposure of onsite individual to airborne radionuclides and toxins when gases build in tank due to a filter failure which fails due to particulate restriction, and the loosed filter media plugs the stack. When the force holding the filter media lodged in the stack are overcome by the pressure that has built up in the tank, the media is dislodged and an unfiltered release occurs.

$F 1-S 1$

1. Potential exposure of occupational individual to airborne radionuclides and toxins when filters fail due to tank over-pressure resulting when a riser in another tank connected to the AWF ventilation system is opened.

\subsection{NODE 6 - MIXING PUMPS}

F3 - S1

1. Potential exposure of onsite individual to radionuclides and toxins when tank containment is breached and tank contents are leaked to the soil column due to impact by missile ejected by mixer pump.

2. Potential exposure of onsite individual to airborne radionuclides and toxins when loss of power to exhaust fan, or exhaust fan failure, allows pressure to build up causing filters to fail which results in an unfiltered release.

\subsection{NODE 7 - EQUIPMENT INSTALLATION AND REMOVAL}

$F 3-S 1$

1. Potential exposure of onsite individual to direct radiation and/or airborne radionuclides and toxins when removing or installing tank equipment.

2. Potential contamination of soil on top of tank resulting from a spill during tank equipment removal. 


\subsection{ACCIDENTS}

The purpose of the accident analysis is to demonstrate assurance that the design and operations resulting from Project $W-151$ can be conducted in a manner that will limit risk to the health and safety of the public and employees and protect the environment. The safety analysis provides the analytical bases for the AWF Tank 241-AZ-101 Waste Retrieval System Safety Requirements. First the facility hazards were identified to determine, to the maximum extent practical, the range of potential accidents or process upsets the facility may experience. Categories of potential accidents were extracted from the hazards assessment and representative scenarios will be developed for each category. Next, dose consequences will be calculated for each scenario. The dose consequences will be compared to the risk acceptance criteria described in WHC-CM-4-46.

\subsection{ACCIDENT SELECTION}

The HAZOP estimates were made for the likelihood of occurrence (Frequency) of each accident shown in the HAZOP study tables. There are four Frequency Categories. Also shown are four Severity Categories. These categories were used along with common release mechanisms to group or bin accidents with comment attributes. Bin or group numbers are shown on the HAZOP study tables.

An accident scenario was developed which bounded a 11 accidents assigned to a bin or group. Six groups or bins were identified. Therefore, six bounding (candidate) accident scenarios were developed. The Bounding candidate accidents are identified in the following section.

\subsection{BOUNDING ACCIDENTS}

Releases of airborne radionuclides and/or toxic materials that have a potential impact on the onsite and/or offsite individual result from ventilation HEPA filter failure, backflow through open tank risers, leakage via failed vent ducting, and installation or removal of tank equipment. Potential exposure of the soil column to tank contents and potential contamination of the ground water could result from a waste tank leak.

The following accidents are specific to Project $W-151$ and bound all other accidents resulting from hazards shown in the HAZOP study tables.

1. Candidate accident that bounds all accidents listed for Bin 1 . Radionuclide release resulting from filter failure due to overpressurization caused by:

- Vacuum breaker fault

- Aerosol generation from chemical reaction

- Ignition of flammable gases in the dome void space

- Increased aerosol generation due to mixer pump action and heat input 
- Plugging of filters with particulate or moisture.

- Tank Bump (sudden release of aerosol with the tank liquid volume) .

2. Candidate accident that bounds all accidents 1isted for Bin 2 . Radionuclide and toxic material release resulting from opening in top of tank due to reversal of flow caused by:

- Wind (air flow over open riser draws aerosols from tank)

- Causes for tank pressurization listed in 1 above while riser is open.

- Tank dome overload resulting in tank dome collapse and breach.

3. Candidate Accident that bounds all accidents 1 isted for Bin 3 . Radionuclide and toxic material release resulting from breach in ventilation ducting due to reversal of flow caused by:

- Seismic event during equipment installation and operation

- High wind during equipment installation and operation

- Impact by construction equipment or vehicle.

4. Candidate accident that bounds all accidents listed for Bin 4. Breach of containment which allows tank contents to enter the soil column creating a potential for a pathway to the ground water beneath the tank caused by:

- Excessive draw down

- Pressure from flammable gas burn

- Dropped equipment into tank during installation or removal

- Missile from pump

- Erosion during mixer pump operation.

5. Candidate accident that bounds all accidents listed for Bin 5 . Radiological and toxic material release resulting form over-pressure due to criticality caused by rearrangement of material due to:

- Mixer pump action during operation or

- Mixer pump action results after mixer pump shutdown.

Criticality Safety Evaluation Report WHC-SD-W151-CSA-001, "CSER 96-014 Criticality Safety of Project W-151, 241-AZ-101

Retrieval System Process Test," will evaluate the criticality safety aspects of the process test. The evaluation extends to the testing and operation of the mixer pumps and does not include the transfer of waste from the tank. The report provides justification that a nuclear criticality is extremely unlikely, if not impossible, in this tank.

6. Radioactive and toxic material release resulting from a seismic event. 
HNF-SD-WM-SARR-042 REV 1

This page intentionally left blank. 
HNF-SD-WM-SARR-042 REV 1

ATTACHMENT 1

HAZOP STUDY TABLES

$3 A-16$ 
HNF-SD-WM-SARR-042 REV 1

This page intentionally left blank. 
Table Al. Team Members - Hazards and Operability Study Project W-151

(February 13 - 15, 1996)

\begin{tabular}{|c|c|c|c|c|c|c|c|}
\hline \multirow{2}{*}{ Team Member } & \multicolumn{7}{|c|}{ NODE } \\
\hline & 1 & 2 & 3 & 4 & 5 & 6 & 7 \\
\hline DATES: & $2 / 13 / 96$ & $2 / 13 / 96$ & $2 / 14 / 96$ & $2 / 14 / 96$ & $2 / 14 / 96$ & $2 / 15 / 96$ & $2 / 15 / 96$ \\
\hline Henry Aguirre Jr. & $x$ & $x$ & $x$ & $x$ & $x$ & $x$ & $x$ \\
\hline Richard E. (Rich) Clayton & $x$ & $x$ & $x$ & $x$ & $x$ & & \\
\hline Burton H. (Burt) Gilbert & $x$ & $x$ & $x$ & $x$ & $x$ & $x$ & $x$ \\
\hline Ronald J. (Ron) Kidder & $x$ & $x$ & $x$ & $x$ & $x$ & $x$ & \\
\hline Roger M. Nelson & $x$ & $x$ & $x$ & $x$ & $x$ & $x$ & $x$ \\
\hline Edward M. (Ed) Nordquist & $x$ & $x$ & $x$ & $x$ & $x$ & $x$ & $x$ \\
\hline Gary R. Tardiff & $x$ & $x$ & $x$ & $x$ & $x$ & $X$ & $X$ \\
\hline
\end{tabular}


Table A2. Ranking Criteria Hazards and Operability Study For Project W-15l Qualitative Accident Severity Levels.

\begin{tabular}{|c|c|}
\hline \multicolumn{2}{|r|}{ Safety Consequence Category Designators } \\
\hline $\begin{array}{l}\text { Category } \\
\text { designation }\end{array}$ & Description \\
\hline S3 & $\begin{array}{l}\text { Potential significant radiological dose consequences or chemical } \\
\text { exposure to the offsite receptor. }\end{array}$ \\
\hline S2 & $\begin{array}{l}\text { Potential significant radiological dose consequences or chemical } \\
\text { exposure to the on-site co-located worker. }\end{array}$ \\
\hline S1 & $\begin{array}{l}\text { Potential industrial injury, radiological dose consequences or } \\
\text { chemical exposure to the facility worker. }\end{array}$ \\
\hline So & $\begin{array}{l}\text { No effect outside the facility confinement systems and no safety } \\
\text { concerns for the facility worker, the onsite worker, or members of the } \\
\text { general public. }\end{array}$ \\
\hline \multicolumn{2}{|r|}{ Environmental Consequence Category Designators } \\
\hline E3 & $\begin{array}{l}\text { Environmental discharges of hazardous material outside the Hanford } \\
\text { Site Boundary or to the groundwater. }\end{array}$ \\
\hline E2 & $\begin{array}{l}\text { Reportable environmental discharge of hazardous material within the } \\
\text { Hanford Site boundary associated with an S2 Safety Consequence. }\end{array}$ \\
\hline El & $\begin{array}{l}\text { Limited environmental discharge of hazardous material outside a } \\
\text { facility associated with an S1 Safety Consequence. }\end{array}$ \\
\hline E0 & No environmental impact. \\
\hline
\end{tabular}


Table A3. Ranking Criteria Hazards and Operability Study For Project W-151.

\begin{tabular}{|c|c|l|}
\hline $\begin{array}{c}\text { Category } \\
\text { designation }\end{array}$ & Numeric definition & \multicolumn{1}{|c|}{ Word definition } \\
\hline F3 & $>10^{-2} /$ year & Anticipated \\
\hline F2 & $>10^{-4}$ to $\leq 10^{-2} /$ year & Unlikely \\
\hline F1 & $>10^{-6}$ to $\leq 10^{-4} /$ year & Extremely Unlikely \\
\hline F0 & $\leq 10^{-6} /$ year & Beyond Extremely Unlikely \\
\hline
\end{tabular}


Figure A1. Project W-151 HAZOP Nodes AWF Waste

Tank 241-AZ-101 Mixer Pump Process Test.

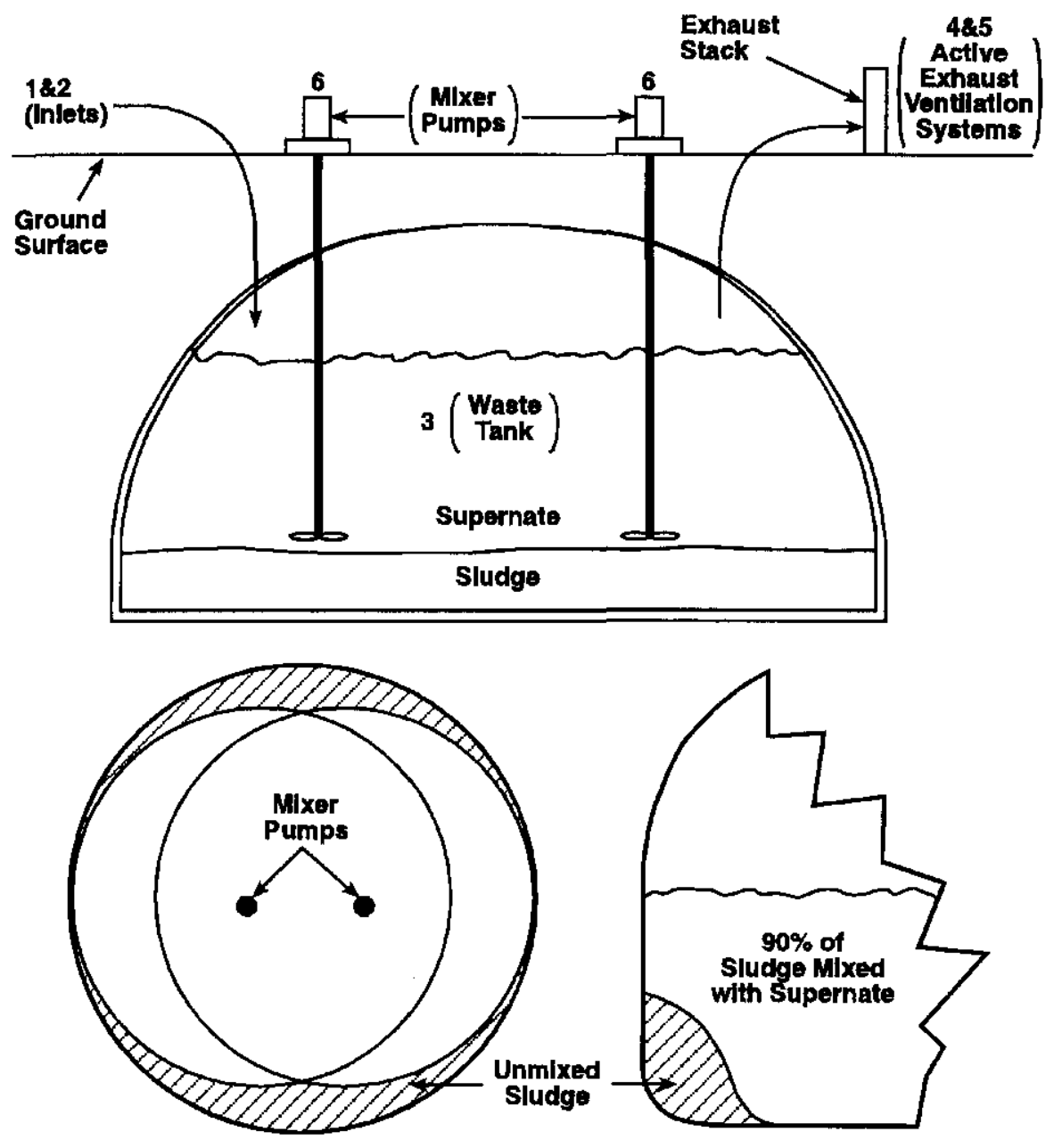

\begin{tabular}{|c|l|}
\hline Node Number & \multicolumn{1}{|c|}{ Node Descriptlon } \\
\hline 1 & Inlet to Old Ventllatlon System \\
\hline 2 & Inlet to New Ventllation System \\
\hline 3 & Waste Tank \\
\hline 4 & Old Exhaust Ventilation System \\
\hline 5 & New Exhaust Ventllatlon System \\
\hline 6 & Mixing Pumps \\
\hline 7 & Equlpment Installation and Removal \\
\hline
\end{tabular}

RG9605104.1

W-151-SD 
Figure A2. Definition of HAZOP Table and

Hazard Summary Table Terms.

\begin{tabular}{|c|c|}
\hline Term & Definition \\
\hline Accident & $\begin{array}{l}\text { An unplanned event or sequence of events that results } \\
\text { in undesirable consequences. }\end{array}$ \\
\hline Cause & $\begin{array}{l}\text { That which produces the effect or consequence of an } \\
\text { accident. }\end{array}$ \\
\hline Consequence & $\begin{array}{l}\text { Effect created by an accident resulting form a hazard } \\
\text { condition: the result or effect of a release of } \\
\text { hazardous material (radiological or chemical) usually } \\
\text { expressed in terms of dose and exposure. }\end{array}$ \\
\hline $\begin{array}{l}\text { Defense in Depth } \\
\text { Controls }\end{array}$ & $\begin{array}{l}\text { Subset of all remaining engineering and } \\
\text { administrative features identified in the hazards } \\
\text { analysis that are not specified as "credited" in the } \\
\text { Hazards Summary Table and which have been agreed as } \\
\text { appropriate for inclusion in the safety } \\
\text { documentation. }\end{array}$ \\
\hline Detection & $\begin{array}{l}\text { Engineering or administrative requirements that are } \\
\text { either already there or that can be introduced to } \\
\text { discover or discern a hazard that may lead to an } \\
\text { accident }\end{array}$ \\
\hline Guide word & $\begin{array}{l}\text { A simple word or phrase used to qualify or quantify } \\
\text { the design intention and associated parameters in } \\
\text { order to discover design deviations or departures } \\
\text { resulting in hazards leading to accidents }\end{array}$ \\
\hline Hazard & $\begin{array}{l}\text { A source of danger with the potential to cause } \\
\text { illness, injury, or death to personnel; or damage to } \\
\text { a facility or to the environment. }\end{array}$ \\
\hline Mitigating Features & $\begin{array}{l}\text { Engineering o administrative requirements that } \\
\text { prevent or reduce the consequences resulting from an } \\
\text { accident }\end{array}$ \\
\hline Node & $\begin{array}{l}\text { The point or location on a process diagram at which } \\
\text { process parameters are investigated for deviations } \\
\text { (or departures from design intent) }\end{array}$ \\
\hline Parameter & $\begin{array}{l}\text { Aspects of a process that describe it physically or } \\
\text { in terms of what is happening }\end{array}$ \\
\hline Rank & $\begin{array}{l}\text { Accident severity and frequency of occurrence } \\
\text { standing }\end{array}$ \\
\hline Receptor & The individual affected by an accident \\
\hline Remark & Comment or observation \\
\hline Risk Bin Number & $\begin{array}{l}\text { Obtained from the RISK MATRIX BIN NUMBERS Table and } \\
\text { is a function of Consequence and Frequency. }\end{array}$ \\
\hline HAZOP Table & $\begin{array}{l}\text { A detailed listing of the hazards identified with a } \\
\text { qualitative evaluation of the consequences }\end{array}$ \\
\hline Hazards Summary Table & $\begin{array}{l}\text { A summary record of the information obtained during } \\
\text { the hazards analysis process. }\end{array}$ \\
\hline
\end{tabular}


Table 1. Hazard and Operability Study - Node 1. (2 sheets)

\begin{tabular}{|c|c|c|c|c|c|c|c|}
\hline \multicolumn{5}{|c|}{ Project: W-151, Tank 241-AZ-101 Waste Retrieval System Date: 02/13/96 } & Node: 1 & \multicolumn{2}{|r|}{ Page: $3 A-23$} \\
\hline \multicolumn{8}{|c|}{$\begin{array}{l}\text { Node Description: Inlet to existing ventilation system. } \\
\text { Design Intention: Provide inlet air for tank dome space ventilation system (cooling and confinement of radioactive particulates). In backflow } \\
\text { situations, exhaust is unfiltered. }\end{array}$} \\
\hline $\begin{array}{l}\text { Parameter/ } \\
\text { Guide word }\end{array}$ & Cause & Consequence & Detection & $\begin{array}{l}\text { Mitigating } \\
\text { Features }\end{array}$ & Rank & $\begin{array}{l}\text { Bin } \\
\text { No. }\end{array}$ & Remark \\
\hline \multirow[t]{6}{*}{ Low/No Flow } & $\begin{array}{l}\text { Over-pressure event in } \\
\text { tank (possibly because } \\
\text { of a blockage to the } \\
\text { exhaust system) }\end{array}$ & $\begin{array}{l}\text { Possible equipment damage } \\
\text { and/or loss of valve function } \\
\text { (could lead to unfiltered } \\
\text { release from breached filter, } \\
\text { hydrogen buildup in tank) } \\
\text { Unfil tered release, tank heat } \\
\text { up. }\end{array}$ & $\begin{array}{l}\text { Dome space pressure } \\
\text { instruments and alarms } \\
\text { Flow elements in } \\
\text { exhaust system }\end{array}$ & $\begin{array}{l}\text { Ventilation } \\
\text { system operating } \\
\text { while mixer pumps } \\
\text { are on or } \\
\text { equipment being } \\
\text { removed }\end{array}$ & $\begin{array}{l}\text { so } \\
\text { F3 }\end{array}$ & 1 & \\
\hline & $\begin{array}{l}\text { Breach of confinement } \\
\text { in another location }\end{array}$ & $\begin{array}{l}\text { Depends on breach size } \\
\text { (either less negative } \\
\text { pressure or atmospheric } \\
\text { release) }\end{array}$ & $\begin{array}{l}\text { Event is probably } \\
\text { linked to construction } \\
\text { or maintenance } \\
\text { activity which will be } \\
\text { known (i.e., visual). }\end{array}$ & $\begin{array}{l}\text { Fix the problem } \\
\text { (portable } \\
\text { exhauster may be } \\
\text { needed dur ing } \\
\text { construction). } \\
\text { Establ ished } \\
\text { control for } \\
\text { opening risers. } \\
\end{array}$ & $\begin{array}{l}\text { so } \\
\text { F3 }\end{array}$ & 1 & \\
\hline & Exhauster failure & $\begin{array}{l}\text { Tank head space pressure } \\
\text { causes filters to breach } \\
\text { leading to unfil tered release } \\
\text { of contaminants to } \\
\text { atmosphere. }\end{array}$ & $\begin{array}{l}\text { Flow meters in the } \\
\text { exhaust line and dp } \\
\text { (different ial } \\
\text { pressure) instrument } \\
\text { and alarms } \\
\text { dp across exhaust } \\
\text { HEPAs zero } \\
\end{array}$ & $\begin{array}{l}\text { Backup exhaust } \\
\text { train }\end{array}$ & $\begin{array}{l}\mathrm{s} 2 \\
\mathrm{F3}\end{array}$ & 1 & \\
\hline & Icing & $\begin{array}{l}\text { High negative pressure in } \\
\text { tank if the exhaust fan } \\
\text { cont inues to run } \\
\text { Inadequate dome space gas } \\
\text { mixing resulting in flammable } \\
\text { gas pockets }\end{array}$ & $\begin{array}{l}\text { Dome space pressure } \\
\text { instruments and alarms }\end{array}$ & $\begin{array}{l}\text { Work control } \\
\text { procedures }\end{array}$ & $\begin{array}{l}\text { so } \\
\text { F3 }\end{array}$ & 1 & \\
\hline & $\begin{array}{l}\text { Stack collapsing } \\
\text { during wind storm }\end{array}$ & Same as exhauster failure. & $\begin{array}{l}\text { Same as exhauster } \\
\text { failure. }\end{array}$ & \begin{tabular}{|l|} 
Design criteria \\
for stack (wind, \\
seismic, SDC4.1)
\end{tabular} & $\begin{array}{l}s 1 \\
F 1\end{array}$ & 1 & \\
\hline & $\begin{array}{l}\text { Failure in another } \\
\text { tank (i.e., open } \\
\text { riser) }\end{array}$ & $\begin{array}{l}\text { Same as breach of confinement } \\
\text { (over-pressurization). }\end{array}$ & $\begin{array}{l}\text { Dome space pressure } \\
\text { instruments and alarm }\end{array}$ & $\begin{array}{l}\text { Work control and } \\
\text { procedures } \\
\text { ventilation } \\
\text { system operating }\end{array}$ & $\begin{array}{l}\text { s1 } \\
\text { F3 }\end{array}$ & 1 & \\
\hline
\end{tabular}


Table 1. Hazard and Operability Study - Node 1. (2 sheets)

\begin{tabular}{|c|c|c|c|c|c|c|c|}
\hline \multicolumn{5}{|c|}{ Project: W-151, Tank 241-Az-101 Waste Retrieval System Date: 02/13/96 } & Node: 1 & & Page: $3 A-24$ \\
\hline \multicolumn{8}{|c|}{$\begin{array}{l}\text { Node Description: Inlet to existing ventilation system. } \\
\text { Design Intention: Provide iniet air for tank dome space ventilation system (cooling and confinement of radioactive particulates). In backflow } \\
\text { situations, exhaust is unfiltered. }\end{array}$} \\
\hline $\begin{array}{l}\text { Parameter/ } \\
\text { Guide word }\end{array}$ & Cause & Consequence & Detection & $\begin{array}{l}\text { Mitigating } \\
\text { Features }\end{array}$ & Rank & $\begin{array}{l}\text { Bin } \\
\text { No. }\end{array}$ & Remark \\
\hline \multirow[t]{2}{*}{ High Flow } & $\begin{array}{l}\text { Vacuum break valve } \\
\text { fault } \\
\text { (fails open) }\end{array}$ & Unfiltered inlet & $\begin{array}{l}\text { HEPA dp instruments } \\
\text { and alarms (low dp on } \\
\text { inlet HEPA filter) }\end{array}$ & $\begin{array}{l}\text { Ventilation } \\
\text { system operating; } \\
\text { may need to } \\
\text { increase tank } \\
\text { farm ventilation } \\
\text { flow rate. }\end{array}$ & $\begin{array}{l}\text { S0 } \\
\text { F2 }\end{array}$ & 1 & $\begin{array}{l}\text { Consider } \\
\text { additional } \\
\text { control for } \\
\text { future mul tiple } \\
\text { waste tank mixer } \\
\text { pump operation. }\end{array}$ \\
\hline & $\begin{array}{l}\text { Ducting breach from } \\
\text { seismic/high wind/ } \\
\text { construction impact }\end{array}$ & $\begin{array}{l}\text { Same as over-pressurization } \\
\text { in tank. }\end{array}$ & $\begin{array}{l}\text { Same as over- } \\
\text { pressurization in } \\
\text { tank. }\end{array}$ & $\begin{array}{l}\text { Work control } \\
\text { procedures; } \\
\text { ventilation } \\
\text { system operating. }\end{array}$ & $\begin{array}{l}\mathrm{s} 1 \\
\mathrm{~F} 2\end{array}$ & 1 & \\
\hline Reverse Flow & Wind or tornado & $\begin{array}{l}\text { Release of radionuclides and } \\
\text { toxic gases through open } \\
\text { riser }\end{array}$ & $\begin{array}{l}\text { Dome space pressure } \\
\text { instruments and alarms }\end{array}$ & \begin{tabular}{l|} 
ventilation \\
system operating \\
Work controls and \\
procedures
\end{tabular} & $\begin{array}{l}\text { s1 } \\
\text { F1 }\end{array}$ & 1 & \\
\hline More Temperature & $\begin{array}{l}\text { Chemical reactions } \\
\text { ignite flammable gases } \\
\text { Heater faulty } \\
\end{array}$ & $\begin{array}{l}\text { Release of unfiltered } \\
\text { radionuclides and toxic gases } \\
\text { due to pressure and heat } \\
\text { causing filters to fail }\end{array}$ & $\begin{array}{l}\text { Dome space pressure } \\
\text { instruments and alarms }\end{array}$ & $\begin{array}{l}\text { Waste } \\
\text { compatibility } \\
\text { program }\end{array}$ & $\begin{array}{l}\text { S2 } \\
\text { F1 }\end{array}$ & 1 & \\
\hline Less Temperature & See icing under No Low & $\begin{array}{l}\text { Release of radionuclides and } \\
\text { toxic gases }\end{array}$ & $\begin{array}{l}\text { Dome space pressure } \\
\text { instruments and alarms }\end{array}$ & $\begin{array}{l}\text { Daily } \\
\text { surveil lances } \\
\text { visual }\end{array}$ & $\begin{array}{l}\text { so } \\
\text { F3 }\end{array}$ & 1 & \\
\hline
\end{tabular}


Table 1. Hazard and Operability Study - Node 2 (3 sheets).

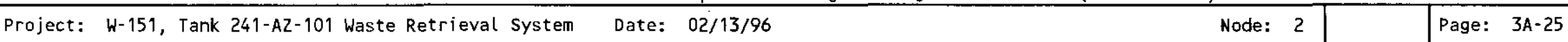

\section{Node Description: Inlet to new ventilation system.}

Design Intention: Provide inlet air for tank dome space ventilation system (cooling and confinement of radioactive particulates) and provide filtered exhaust in backflow situations ( $W$-030 upgrade).

\begin{tabular}{|c|c|c|c|c|c|c|c|}
\hline $\begin{array}{l}\text { Parameter/ } \\
\text { Guide word }\end{array}$ & Cause & Consequence & Detection & $\begin{array}{l}\text { Mitigating } \\
\text { Features } \\
\end{array}$ & Rank & $\begin{array}{l}\text { Bin } \\
\text { No. }\end{array}$ & Remark \\
\hline \multirow[t]{7}{*}{ Low/No Flow } & $\begin{array}{l}\text { Over-pressure event in } \\
\text { tank because of a } \\
\text { faulty valve to the } \\
\text { exhaust system. }\end{array}$ & $\begin{array}{l}\text { Possible equipment damage } \\
\text { and/or valve function leads } \\
\text { to unfiltered release when } \\
\text { valve remains closed allowing } \\
\text { pressure buildup, then valve } \\
\text { opens allowing pressure to } \\
\text { fail filters causing an } \\
\text { unfiltered release. } \\
\end{array}$ & $\begin{array}{l}\text { Dome space instruments } \\
\text { and alarms } \\
\text { Flow Alarm in inlet } \\
\text { system }\end{array}$ & $\begin{array}{l}\text { Inlet air filters } \\
\text { and Condensers }\end{array}$ & $\begin{array}{l}\text { S1 } \\
\text { F3 }\end{array}$ & 1 & \\
\hline & $\begin{array}{l}\text { Inlet HEPA plugging } \\
\text { (water, condensation, } \\
\text { debris) }\end{array}$ & $\begin{array}{l}\text { High negative pressure in } \\
\text { tank if the exhaust fan } \\
\text { cont inues to run }\end{array}$ & $\begin{array}{l}\text { Visual inspection of } \\
\text { filter screens on } \\
\text { inlet; HEPA dp } \\
\text { indicators and } \\
\text { alarms; dome space } \\
\text { instruments and alarms }\end{array}$ & $\begin{array}{l}\text { Daily } \\
\text { surveillance and } \\
\text { maintenance } \\
\text { program }\end{array}$ & $\begin{array}{l}\text { so } \\
\text { F3 }\end{array}$ & 1 & $\begin{array}{l}\text { Differential } \\
\text { pressure (dp) }\end{array}$ \\
\hline & & $\begin{array}{l}\text { Inadequate dome space gas } \\
\text { mixing resulting in flammable } \\
\text { gas pockets }\end{array}$ & $\begin{array}{l}\text { HEPA dp indicators and } \\
\text { alarms; dome space } \\
\text { pressure instruments } \\
\text { and alarms }\end{array}$ & $\begin{array}{l}\text { Daily } \\
\text { surveillance and } \\
\text { maintenance } \\
\text { program } \\
\end{array}$ & $\begin{array}{l}\text { so } \\
\text { F3 }\end{array}$ & 1 & \\
\hline & $\begin{array}{l}\text { Breach of conf inement } \\
\text { in another location }\end{array}$ & $\begin{array}{l}\text { Depends on breach size } \\
\text { (either less negative } \\
\text { pressure or atmospheric } \\
\text { release) }\end{array}$ & $\begin{array}{l}\text { Event is probably } \\
\text { linked to construction } \\
\text { or maintenance } \\
\text { activity which will be } \\
\text { known (i.e., visual). }\end{array}$ & $\begin{array}{l}\text { Repair the } \\
\text { problem (portable } \\
\text { exhauster may be } \\
\text { needed during } \\
\text { construction). } \\
\text { Instituted } \\
\text { controls for } \\
\text { opening risers. } \\
\end{array}$ & $\begin{array}{l}\text { so } \\
\text { F3 }\end{array}$ & 1 & \\
\hline & Exhauster failure & $\begin{array}{l}\text { Over-pressure in the tank } \\
\text { causing filter failure and } \\
\text { potential atmospheric release }\end{array}$ & $\begin{array}{l}\text { Flow meter in the } \\
\text { inlet; pressure dome } \\
\text { space instruments and } \\
\text { alarms; HEPA dp } \\
\text { instruments and al arms } \\
\end{array}$ & $\begin{array}{l}\text { Backup exhaust } \\
\text { train; daily } \\
\text { surveillance and } \\
\text { maintenance } \\
\text { program } \\
\end{array}$ & 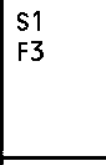 & 1 & \\
\hline & $\begin{array}{l}\text { Icing due to heater } \\
\text { failure }\end{array}$ & Same as inlet HEPA plugging & $\begin{array}{l}\text { visual inspection of } \\
\text { filter screens on } \\
\text { inlet; dp instruments } \\
\text { across inlet HEPAs and } \\
\text { alarms }\end{array}$ & $\begin{array}{l}\text { System bypass } \\
\text { available (vacuum } \\
\text { break); daily } \\
\text { surveil lance }\end{array}$ & $\begin{array}{l}\text { so } \\
\text { F3 }\end{array}$ & 1 & \\
\hline & $\begin{array}{l}\text { Stack collapsing } \\
\text { during wind storm }\end{array}$ & Same as exhauster failure & $\begin{array}{l}\text { Same as exhauster } \\
\text { failure }\end{array}$ & $\begin{array}{l}\text { Design criteria } \\
\text { for stack (wind, } \\
\text { seismic, SDC } 4.1 \text { ) }\end{array}$ & $\begin{array}{l}\text { S1 } \\
\text { F1 }\end{array}$ & 1 & \\
\hline
\end{tabular}


Table 1. Hazard and Operability Study - Node 2 ( 3 sheets).

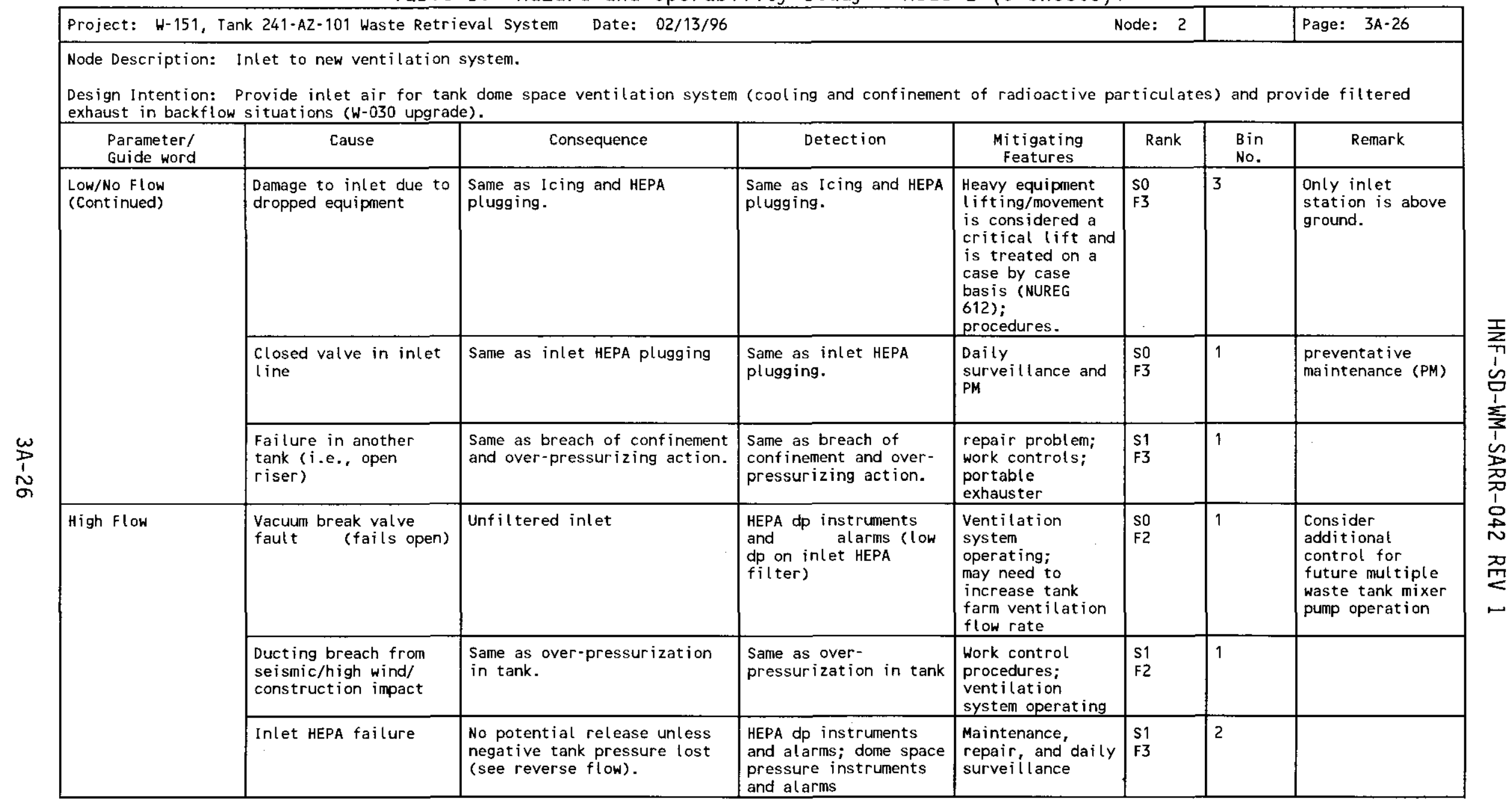


Table 1. Hazard and Operability Study - Node 2 (3 sheets).

\begin{tabular}{|c|c|c|c|c|c|c|c|}
\hline Project: $W-151, T$ & k 241-AZ-101 Waste Retri & eval System Date: 02/13/96 & & & ode: 2 & & Page: $3 A-27$ \\
\hline \multicolumn{8}{|c|}{$\begin{array}{l}\text { Node Description: Inlet to new ventilation system. } \\
\text { Design Intention: Provide inlet air for tank dome space ventilation system (cooling and confinement of radioactive particulates) and provide filtered } \\
\text { exhaust in backflow situations ( } W-030 \text { upgrade). }\end{array}$} \\
\hline $\begin{array}{l}\text { Parameter/ } \\
\text { Guide word }\end{array}$ & Cause & Consequence & Detection & $\begin{array}{l}\text { Mitigating } \\
\text { Features }\end{array}$ & Rank & $\begin{array}{l}\text { Bin } \\
\text { No. }\end{array}$ & Remark \\
\hline \multirow[t]{2}{*}{ Reverse Flow } & $\begin{array}{l}\text { Natural draft (wind } \\
\text { blowing across inlet } \\
\text { with open riser) }\end{array}$ & $\begin{array}{l}\text { Release of radionuclides and } \\
\text { toxic gases }\end{array}$ & $\begin{array}{l}\text { Dome space pressure } \\
\text { instruments and } \\
\text { alarms; inlet flow } \\
\text { instruments and alarms }\end{array}$ & $\begin{array}{l}\text { HEPA filters on } \\
\text { inlet will filter } \\
\text { reverse flow. }\end{array}$ & $\begin{array}{l}\text { S1 } \\
\text { F1 }\end{array}$ & 2 & \\
\hline & $\begin{array}{l}\text { Ignition of flammable } \\
\text { gases in the dome } \\
\text { space melt inlet HEPAs }\end{array}$ & $\begin{array}{l}\text { Release of unfiltered } \\
\text { radionucl ides and toxic gases } \\
\text { due to heat and pressure } \\
\text { which causes filter failure }\end{array}$ & $\begin{array}{l}\text { HEPA dp instruments } \\
\text { and alarms; stack flow } \\
\text { instruments and alarms }\end{array}$ & $\begin{array}{l}\text { work controls } \\
\text { (mixer pump } \\
\text { controlled } \\
\text { startup) }\end{array}$ & $\begin{array}{l}\text { S2 } \\
\text { F2 }\end{array}$ & 1 & $\begin{array}{l}\text { Consider } \\
\text { monitoring of } \\
\text { gas } \\
\text { concentration in } \\
\text { tank head space } \\
\text { prior to and } \\
\text { during mixer } \\
\text { pump operation. }\end{array}$ \\
\hline \multirow[t]{2}{*}{ More Temperature } & $\begin{array}{l}\text { Ignition of flammable } \\
\text { gases in the dome } \\
\text { space melt inlet HEPAs }\end{array}$ & $\begin{array}{l}\text { Release of unfiltered } \\
\text { radionuclides and toxic gases } \\
\text { due to heat and pressure } \\
\text { which causes filter failure }\end{array}$ & $\begin{array}{l}\text { HEPA dp instruments } \\
\text { and alarms; stack flow } \\
\text { instruments and alarms }\end{array}$ & $\begin{array}{l}\text { work controls } \\
\text { (mixer pump } \\
\text { control led } \\
\text { startup) }\end{array}$ & $\begin{array}{l}\text { S2 } \\
\text { F2 }\end{array}$ & 1 & $\begin{array}{l}\text { Consider } \\
\text { monitoring of } \\
\text { gas } \\
\text { concentration in } \\
\text { tank head space } \\
\text { prior to and } \\
\text { during mixer } \\
\text { pump operation. } \\
\end{array}$ \\
\hline & $\begin{array}{l}\text { Heat from chemical } \\
\text { reactions ignite } \\
\text { flammable gases. } \\
\text { Heater fault ignites } \\
\text { flammable gases }\end{array}$ & $\begin{array}{l}\text { Release of radionuclides and } \\
\text { toxic gases }\end{array}$ & $\begin{array}{l}\text { HEPA dp instruments } \\
\text { and alarms; stack flow } \\
\text { instruments and alarms }\end{array}$ & $\begin{array}{l}\text { Waste } \\
\text { compatibility } \\
\text { program; heater } \\
\text { PM; daily } \\
\text { surveillance; } \\
\text { work controls } \\
\end{array}$ & $\begin{array}{l}\mathrm{S} 2 \\
\mathrm{~F} 1\end{array}$ & 1 & \\
\hline Less Temperature & $\begin{array}{l}\text { See plugging and icing } \\
\text { under "No Flow." }\end{array}$ & Same as plugging & $\begin{array}{l}\text { Visual and dp } \\
\text { instruments and alarms }\end{array}$ & $\begin{array}{l}\text { Heater PM and } \\
\text { daily } \\
\text { surveillance }\end{array}$ & So & 1 & \\
\hline
\end{tabular}


Table 1. Hazard and Operability Study - Node 3 (6 sheets).

\begin{tabular}{|c|c|c|c|c|c|c|c|}
\hline \multicolumn{5}{|c|}{ Project: W-151, Tank 241-AZ-101 Waste Retrieval System Date: 02/14/96 } & \multicolumn{2}{|l|}{ Node: 3} & Page: $3 A-28$ \\
\hline \multicolumn{8}{|c|}{$\begin{array}{l}\text { Node Description: Waste Tank } \\
\text { Design Intention: Encompass tank liquid containnent and vapor head space confinement. }\end{array}$} \\
\hline $\begin{array}{l}\text { Parameter/ } \\
\text { Guide word }\end{array}$ & Cause & Consequence & Detection & $\begin{array}{l}\text { Mitigating } \\
\text { Features } \\
\end{array}$ & Rank & $\begin{array}{l}\text { BIN } \\
\text { NO. }\end{array}$ & Remark \\
\hline \multirow[t]{5}{*}{ High Level } & $\begin{array}{l}\text { Mixer pump seal } \\
\text { failure (Bearing } \\
\text { water drains to tank } \\
\text { faster than normal.) }\end{array}$ & Increase in tank level & $\begin{array}{l}\text { Tank level instruments } \\
\text { and alarms }\end{array}$ & $\begin{array}{l}\text { Administrative } \\
\text { control on } \\
\text { addition of } \\
\text { water; daity } \\
\text { surveillances; } \\
\text { design features } \\
\text { (disaster } \\
\text { bushings, maximum } \\
\text { flow orifice) } \\
\end{array}$ & $\begin{array}{l}\text { SO } \\
\text { F3 }\end{array}$ & $\begin{array}{l}\text { See } \\
\text { remarks }\end{array}$ & $\begin{array}{l}\text { Not binned } \\
\text { because there is } \\
\text { no release. }\end{array}$ \\
\hline & $\begin{array}{l}\text { Loss of spray water } \\
\text { control during } \\
\text { equipment removal } \\
\text { from tank via riser }\end{array}$ & Increase in tank level & $\begin{array}{l}\text { Tank level instruments } \\
\text { and alarms }\end{array}$ & $\begin{array}{l}\text { Limited volume } \\
(4,500 \text { gal tanker } \\
\text { truck })\end{array}$ & so & $\begin{array}{l}\text { Same as } \\
\text { above. }\end{array}$ & Same as above. \\
\hline & $\begin{array}{l}\text { Mis-transfer due to } \\
\text { mis-routing }\end{array}$ & Increase in tank level & $\begin{array}{l}\text { Tank level instruments } \\
\text { and alarms } \\
\end{array}$ & \begin{tabular}{|l|} 
Operating \\
procedures
\end{tabular} & $\begin{array}{l}\text { SO } \\
\text { F3 } \\
\end{array}$ & $\begin{array}{l}\text { Same as } \\
\text { above. }\end{array}$ & Same as Above. \\
\hline & External flooding & $\begin{array}{l}\text { release of tank contents to } \\
\text { environment }\end{array}$ & Visual & & $\begin{array}{l}\text { S3 } \\
\text { FO }\end{array}$ & $\begin{array}{l}\text { Same as } \\
\text { above. }\end{array}$ & $\begin{array}{l}\text { External } \\
\text { flooding is } \\
\text { considered } \\
\text { incredible. }\end{array}$ \\
\hline & Mixer pump insertion & $\begin{array}{l}\text { displacement of tank waste } \\
\text { leading to increase in tank } \\
\text { level (very small) }\end{array}$ & $\begin{array}{l}\text { Level instruments and } \\
\text { alarms }\end{array}$ & $\begin{array}{l}\text { Level will be } \\
\text { known prior to } \\
\text { pump insertion. } \\
\text { Tank surveillance } \\
\text { requirements }\end{array}$ & $\begin{array}{l}\text { So } \\
\text { F3 }\end{array}$ & $\begin{array}{l}\text { Same as } \\
\text { above. }\end{array}$ & $\begin{array}{l}\text { Mixer pump } \\
\text { displacement } \\
\text { will be range of } \\
500 \text { gallons. }\end{array}$ \\
\hline Low Level & $\begin{array}{l}\text { Breach of containment } \\
\text { due to equipment drop } \\
\text { during installation } \\
\text { or removal }\end{array}$ & $\begin{array}{l}\text { Leakage of tank waste to soil } \\
\text { column }\end{array}$ & $\begin{array}{l}\text { Tank level instruments } \\
\text { and alarms; Primary } \\
\text { tank leak detection } \\
\text { system } \\
\text { (Annulus conductivity } \\
\text { probes and continuous } \\
\text { air monitor) }\end{array}$ & $\begin{array}{l}\text { Critical lift } \\
\text { work procedures } \\
\text { and job controls } \\
\text { Energy absorption } \\
\text { cylinder } \\
\begin{array}{l}\text { Secondary } \\
\text { containment } \\
\text { (Annulus) }\end{array} \\
\end{array}$ & $\begin{array}{l}\text { S3 } \\
\text { F1 }\end{array}$ & 4 & \\
\hline
\end{tabular}


Table 1. Hazard and Operability Study - Node 3 (6 sheets).

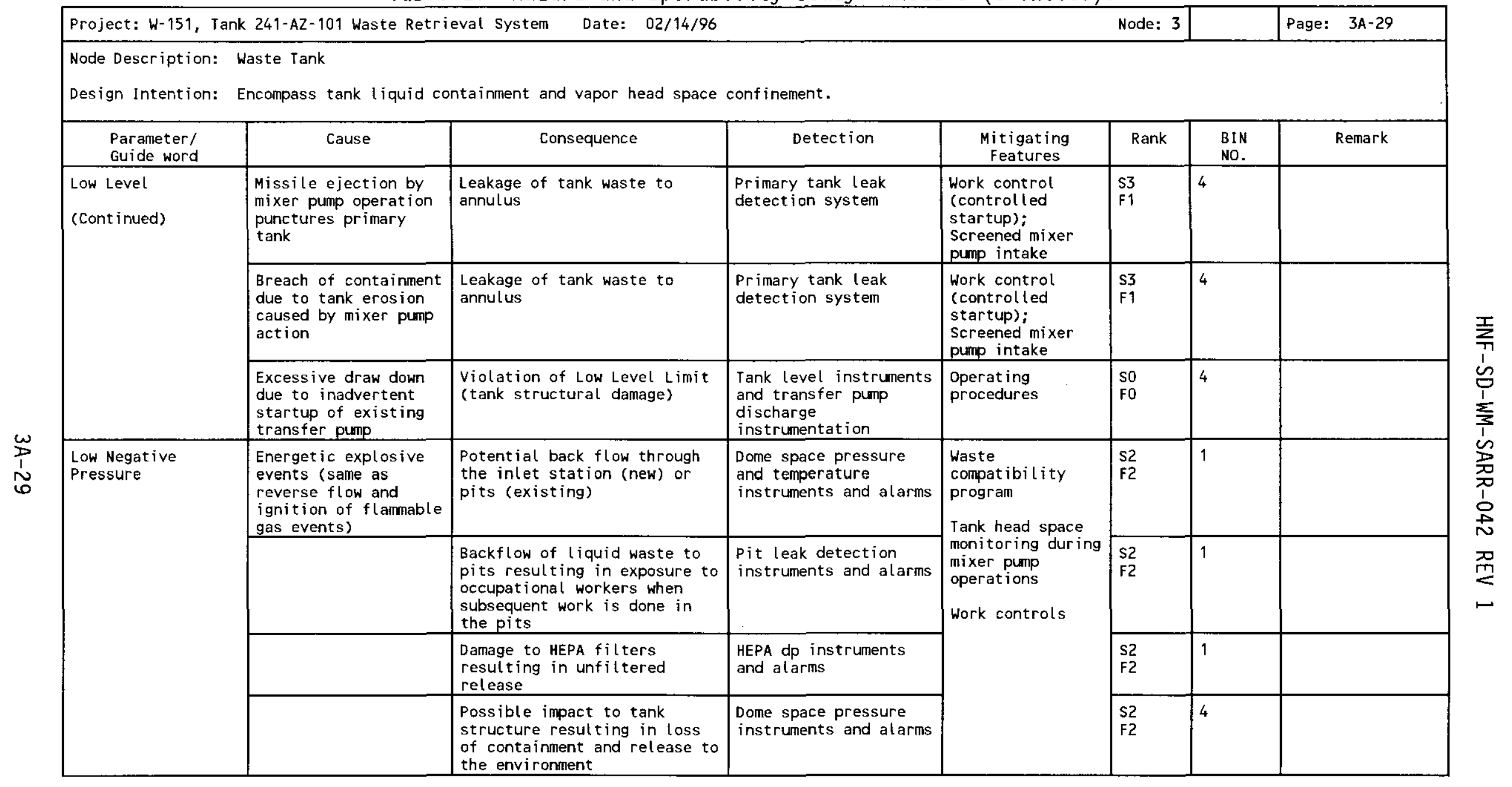


Table 1. Hazard and Operability Study - Node 3 (6 sheets).

\begin{tabular}{|c|c|c|c|c|c|c|c|}
\hline \multicolumn{5}{|c|}{ Project: W-151, Tank 241-Az-101 Waste Retrieval System Date: 02/14/96 } & Node: 3 & & Page: $3 A-30$ \\
\hline \multicolumn{8}{|c|}{$\begin{array}{l}\text { Node Description: Waste Tank } \\
\text { Design Intention: Encompass tank liquid containment and vapor head space confinement. }\end{array}$} \\
\hline $\begin{array}{l}\text { Parameter/ } \\
\text { Guide word }\end{array}$ & Cause & Consequence & Detection & $\begin{array}{l}\text { Mitigating } \\
\text { Features }\end{array}$ & Rank & $\begin{array}{l}\text { BIN } \\
\text { NO. }\end{array}$ & Remark \\
\hline \multirow[t]{5}{*}{$\begin{array}{l}\text { Low Negative } \\
\text { Pressure } \\
\text { (Cont inued) }\end{array}$} & $\begin{array}{l}\text { Inadequate exhauster } \\
\text { operation }\end{array}$ & $\begin{array}{l}\text { Loss of confinement } \\
\text { (potential unfiltered } \\
\text { release) }\end{array}$ & $\begin{array}{l}\text { Dome space pressure } \\
\text { instruments and } \\
\text { alarms, HEPA dp } \\
\text { instruments and alarms }\end{array}$ & $\begin{array}{l}\text { Proper system } \\
\text { balance and } \\
\text { maintenance, dp } \\
\text { across } f i l t e r \\
\text { banks, al arms, } \\
\text { and shutdown } \\
\text { vent } i \text { lation } \\
\text { system } \\
\text { Redundant } \\
\text { vent } i \text { lation } \\
\text { system } \\
\end{array}$ & $\begin{array}{l}\text { S1 } \\
\text { F3 }\end{array}$ & 1 & $\begin{array}{l}\text { Consider } \\
\text { backup/standby } \\
\text { portable } \\
\text { exhauster during } \\
\text { operations. }\end{array}$ \\
\hline & $\begin{array}{l}\text { High volume input } \\
\text { (Same as for High } \\
\text { Flow in Node } 2 \text { vacuum } \\
\text { break valve fault.) }\end{array}$ & $\begin{array}{l}\text { Possible wetting of filters } \\
\text { if cont inued long enough }\end{array}$ & $\begin{array}{l}\text { Same as for High } \mathrm{Flow} \\
\text { in Node } 2 \text {. }\end{array}$ & $\begin{array}{l}\text { Control of } \\
\text { transfer rate; } \\
\text { HEPA dp would be } \\
\text { an indication of } \\
\text { success. } \\
\text { Same as for High } \\
\text { Flow in Node } 2 \text {. } \\
\end{array}$ & $\begin{array}{l}\text { so } \\
\text { F2 }\end{array}$ & 1 & \\
\hline & $\begin{array}{l}\text { Events at tank or } \\
\text { other tanks (opening } \\
\text { risers) }\end{array}$ & $\begin{array}{l}\text { Same as inadequate exhauster } \\
\text { operation. }\end{array}$ & $\begin{array}{l}\text { Same as inadequate } \\
\text { exhauster operation. }\end{array}$ & $\begin{array}{l}\text { Same as } \\
\text { inadequate } \\
\text { exhauster } \\
\text { operation. }\end{array}$ & $\begin{array}{l}\text { S1 } \\
\text { F3 }\end{array}$ & 1 & \\
\hline & $\begin{array}{l}\text { Excess gas release } \\
\text { from mixer pump } \\
\text { operation }\end{array}$ & $\begin{array}{l}\text { Potential for greater } \\
\text { concentrations of toxins, } \\
\text { flamable gases and } \\
\text { radionuclide particles } \\
\text { resulting in over-pressure } \\
\text { that fails filter causing an } \\
\text { unfiltered release. }\end{array}$ & $\begin{array}{l}\text { Stack monitoring } \\
\text { instruments and alarms }\end{array}$ & $\begin{array}{l}\text { Controlled } \\
\text { startup of mixer } \\
\text { pumps }\end{array}$ & $\begin{array}{l}\text { S1 } \\
\text { F2 }\end{array}$ & 1 & \\
\hline & $\begin{array}{l}\text { Mixer pump causes } \\
\text { unexpected chemical } \\
\text { reaction }\end{array}$ & $\begin{array}{l}\text { Same as for "chemical } \\
\text { reactions ignite flammable } \\
\text { gases" in Node } 2 \text {. }\end{array}$ & $\begin{array}{l}\text { Same as for "chemical } \\
\text { reactions ignite } \\
\text { flammable gases" in } \\
\text { Node } 2 \text {. }\end{array}$ & $\begin{array}{l}\text { Same as for } \\
\text { "chemical } \\
\text { reactions ignite } \\
\text { flammable gases } \\
\text { in Node } 2 . \\
\end{array}$ & $\begin{array}{l}\text { S2 } \\
\text { F1 }\end{array}$ & 1 & \\
\hline $\begin{array}{l}\text { High Negative } \\
\text { Pressure }\end{array}$ & $\begin{array}{l}\text { Same as Node } 1 \text { No/Low } \\
\text { Flow tank over- } \\
\text { Pressure event. }\end{array}$ & $\begin{array}{l}\text { Same as Node } 1 \text { No/Low Flow } \\
\text { tank over-pressure event. }\end{array}$ & $\begin{array}{l}\text { Same as Node } 1 \text { No/Low } \\
\text { F low tank over- } \\
\text { pressure event. }\end{array}$ & & $\begin{array}{l}\text { SO } \\
\text { F3 }\end{array}$ & 1 & \\
\hline
\end{tabular}


Table 1. Hazard and Operability Study - Node 3 (6 sheets).

\begin{tabular}{|c|c|c|c|c|c|c|c|}
\hline \multicolumn{5}{|c|}{ Project: W-151, Tank 241-AZ-101 Waste Retrieval System Date: 02/14/96 } & Node: 3 & & Page: $3 A-31$ \\
\hline \multicolumn{8}{|c|}{$\begin{array}{l}\text { Node Description: Waste Tank } \\
\text { Design Intention: Encompass tank Liquid containment and vapor head space confinement. }\end{array}$} \\
\hline $\begin{array}{l}\text { Parameter/ } \\
\text { Guide word }\end{array}$ & Cause & Consequence & Detection & $\begin{array}{l}\text { Mitigating } \\
\text { Features }\end{array}$ & Rank & $\begin{array}{l}\text { BIN } \\
\text { NO. }\end{array}$ & Remark \\
\hline \multirow[t]{4}{*}{$\begin{array}{l}\text { Vapor Space } \\
\text { Composition Change }\end{array}$} & \multirow[t]{3}{*}{ Mixer pump operation } & $\begin{array}{l}\text { Increased aerosol loading } \\
\text { from heat or splashing } \\
\text { results in over-pressurizing } \\
\text { filters and an unfiltered } \\
\text { release. }\end{array}$ & $\begin{array}{l}\text { HEPA filter dp; } \\
\text { monitoring of dome } \\
\text { space activity }\end{array}$ & $\begin{array}{l}\text { Control led } \\
\text { startup of mixer } \\
\text { pumps }\end{array}$ & $\begin{array}{l}\text { S1 } \\
\text { F2 }\end{array}$ & 1 & \\
\hline & & $\begin{array}{l}\text { Potential higher activity in } \\
\text { tank dome space }\end{array}$ & $\begin{array}{l}\text { HEPA filter dp and } \\
\text { stack monitor } \\
\text { instruments and al arms } \\
\text { Monitoring of } \\
\text { ventilation exhaust } \\
\text { during mixer pump } \\
\text { operation } \\
\text { Portable humidity } \\
\text { monitor available } \\
\end{array}$ & $\begin{array}{l}\text { Controlled } \\
\text { startup of mixer } \\
\text { pumps }\end{array}$ & $\begin{array}{l}\text { S1 } \\
\text { F3 }\end{array}$ & 1 & \\
\hline & & $\begin{array}{l}\text { Potential higher } \\
\text { concentration of } \\
\text { flammable/toxic gases and } \\
\text { heat resulting in over- } \\
\text { pressure causing filter } \\
\text { failure and an unfiltered } \\
\text { release }\end{array}$ & $\begin{array}{l}\text { Gas samplers and } \\
\text { activity monitors in } \\
\text { the exhaust stack } \\
\text { Monitoring of dome } \\
\text { space concentrations } \\
\text { during mixer pump } \\
\text { operation }\end{array}$ & $\begin{array}{l}\text { Controlled } \\
\text { startup of mixer } \\
\text { pumps; } \\
\text { operation of } \\
\text { vent ilation } \\
\text { system }\end{array}$ & $\begin{array}{l}\text { S1 } \\
\text { F3 }\end{array}$ & 1 & \\
\hline & $\begin{array}{l}\text { Increase in vapor } \\
\text { space as tank level } \\
\text { is drawn down. }\end{array}$ & $\begin{array}{l}\text { Stratification of the vapor } \\
\text { resulting in a possible } \\
\text { buildup of gas concentration } \\
\text { due to decreased air sweep } \\
\text { ability }\end{array}$ & Tank level indication & $\begin{array}{l}\text { Consider } \\
\text { increased } \\
\text { vent ilation } \\
\text { system flow if } \\
\text { conditions } \\
\text { warrant it. } \\
\end{array}$ & $\begin{array}{l}\text { S0 } \\
\text { F1 }\end{array}$ & 1 & $\begin{array}{l}\text { Assumed gas } \\
\text { concentrat ion as } \\
\text { below } 25 \% \text { of LFL } \\
\text { (dropped from } \\
\text { OSD-0030 } \\
\text { Appendix B). } \\
\end{array}$ \\
\hline More Temperature & $\begin{array}{l}\text { Tank material } \\
\text { rol lover }\end{array}$ & $\begin{array}{l}\text { Potential higher } \\
\text { concentration of } \\
\text { flammable/toxic gases; } \\
\text { increased release of toxic } \\
\text { gases via the exhaust system }\end{array}$ & $\begin{array}{l}\text { Gas samplers and stack } \\
\text { moni tor instruments } \\
\text { and alarms; vapor } \\
\text { space flammable gas } \\
\text { moni toring; dome space } \\
\text { pressure instruments } \\
\text { and alarms }\end{array}$ & $\begin{array}{l}\text { Operation of } \\
\text { ventilation } \\
\text { system; } \\
\text { controlled } \\
\text { startup of mixers }\end{array}$ & $\begin{array}{l}\text { S1 } \\
\text { Fo }\end{array}$ & 1 & $\begin{array}{l}\text { With the current } \\
\text { material } \\
\text { composition in } \\
\text { this tank } \\
\text { rollover is not } \\
\text { considered } \\
\text { credible. This } \\
\text { tank is not on } \\
\text { watch list. }\end{array}$ \\
\hline
\end{tabular}


Table 1. Hazard and Operability Study - Node 3 (6 sheets).

\begin{tabular}{|c|c|c|c|c|c|c|c|}
\hline \multicolumn{5}{|c|}{ Project: W-151, Tank 241-AZ-101 Waste Retrieval System Date: 02/14/96 } & \multicolumn{2}{|l|}{ Node: 3} & \multirow[t]{2}{*}{ Page: $3 A-32$} \\
\hline \multicolumn{7}{|c|}{$\begin{array}{l}\text { Node Description: Waste Tank } \\
\text { Design Intention: Encompass tank liquid containment and vapor head space confinement. }\end{array}$} & \\
\hline $\begin{array}{l}\text { Parameter/ } \\
\text { Guide word }\end{array}$ & Cause & Consequence & Detection & $\begin{array}{l}\text { Mitigating } \\
\text { Features } \\
\end{array}$ & Rank & $\begin{array}{l}\text { BIN } \\
\text { NO. }\end{array}$ & Remark \\
\hline \multirow[t]{8}{*}{$\begin{array}{l}\text { More Temperature } \\
\text { (Cont inued) }\end{array}$} & \multirow[t]{2}{*}{$\begin{array}{l}\text { Tank material } \\
\text { rol lover } \\
\text { (Cont inued) }\end{array}$} & Increased aerosol loading & $\begin{array}{l}\text { Gas samplers and } \\
\text { activity moni tors in } \\
\text { the exhaust stack; } \\
\text { vapor space flammable } \\
\text { gas monitoring; dome } \\
\text { space pressure } \\
\text { instruments and alarms }\end{array}$ & $\begin{array}{l}\text { Operations of } \\
\text { ventilation } \\
\text { system; } \\
\text { controlled } \\
\text { startup of mixers }\end{array}$ & $\begin{array}{l}\text { s1 } \\
\text { Fo }\end{array}$ & 1 & \\
\hline & & Higher activity in dome space & $\begin{array}{l}\text { Gas samplers and } \\
\text { activity monitors in } \\
\text { the exhaust stack; } \\
\text { vapor space flammable } \\
\text { gas monitoring; dome } \\
\text { space pressure } \\
\text { instruments and alarms }\end{array}$ & $\begin{array}{l}\text { Operations of } \\
\text { ventilation } \\
\text { system; } \\
\text { control led } \\
\text { startup of mixers }\end{array}$ & $\begin{array}{l}\text { S1 } \\
\text { Fo }\end{array}$ & 1 & \\
\hline & Explosion event & $\begin{array}{l}\text { Release of unfiltered } \\
\text { radionucl ides and toxic gases } \\
\text { due to heat and pressure } \\
\text { which causes filter failure } \\
\end{array}$ & $\begin{array}{l}\text { HEPA dp instruments } \\
\text { and alarms; stack } \\
\text { flow instruments and } \\
\text { al arms }\end{array}$ & $\begin{array}{l}\text { work controls } \\
\text { (mixer punp } \\
\text { controlled } \\
\text { startup) }\end{array}$ & $\begin{array}{l}\text { s2 } \\
\text { F2 }\end{array}$ & 1 & \\
\hline & \begin{tabular}{|l} 
Fire event \\
(deflagration)
\end{tabular} & See Node 1 More Temperature. & & & $\begin{array}{l}\mathrm{S} 2 \\
\mathrm{F2} \\
\end{array}$ & 1 & \\
\hline & $\begin{array}{l}\text { Increased temperature } \\
\text { of the waste due to } \\
\text { mixer pump heat input }\end{array}$ & See tank material rollover. & & & $\begin{array}{l}\text { S1 } \\
\text { F3 }\end{array}$ & 1 & \\
\hline & $\begin{array}{l}\text { Extended low air flow } \\
\text { in tank head space }\end{array}$ & $\begin{array}{l}\text { Refer to exhaust/ inlet nodes } \\
\text { (Node } 4 \text { Low Flow and Node } 3 \\
\text { Low Negative Pressure). } \\
\end{array}$ & & & $\begin{array}{l}\text { So } \\
\text { F3 }\end{array}$ & 1 & \\
\hline & $\begin{array}{l}\text { Loss of cool ing/heat } \\
\text { exchanger failure }\end{array}$ & $\begin{array}{l}\text { See Nodes } 4 \text { and } 5 \text { Less } \\
\text { Temperature. }\end{array}$ & & & & 1 & \\
\hline & Chemical reaction & $\begin{array}{l}\text { Over-pressurization potential } \\
\text { for fire and explosion }\end{array}$ & $\begin{array}{l}\text { Dome space pressure } \\
\text { instruments and alarms }\end{array}$ & $\begin{array}{l}\text { Waste } \\
\text { compatibility } \\
\text { program }\end{array}$ & $\begin{array}{l}\text { S2 } \\
\text { F1 }\end{array}$ & 1 & \\
\hline
\end{tabular}


Table 1. Hazard and Operability Study - Node 3 ( 6 sheets).

\begin{tabular}{|c|c|c|c|c|c|c|c|}
\hline \multicolumn{5}{|c|}{ Project: W-151, Tank 241-AZ-101 Waste Retrieval System Date: 02/14/96 } & Node: 3 & & Page: $3 A-33$ \\
\hline \multicolumn{8}{|c|}{$\begin{array}{l}\text { Node Description: Waste Tank } \\
\text { Design Intention: Encompass tank liquid containment and vapor head space confinement. }\end{array}$} \\
\hline $\begin{array}{l}\text { Parameter/ } \\
\text { Guide word }\end{array}$ & Cause & Consequence & Detection & $\begin{array}{l}\text { Mitigating } \\
\text { Features } \\
\end{array}$ & Rank & $\begin{array}{l}\text { BIN } \\
\text { NO. }\end{array}$ & Remark \\
\hline $\begin{array}{l}\text { More Temperature } \\
\text { (Cont inued) }\end{array}$ & $\begin{array}{l}\text { Redistribution of } \\
\text { layers at the start } \\
\text { of mixing }\end{array}$ & $\begin{array}{l}\text { Potential release of } \\
\text { flammable and toxic gases and } \\
\text { radionuclides and steam } \\
\text { causing filter failure and } \\
\text { unfiltered release }\end{array}$ & $\begin{array}{l}\text { Dome space pressure } \\
\text { instruments and alarms } \\
\text { Temp thermocouple } \\
\text { indications; gas } \\
\text { monitoring }\end{array}$ & $\begin{array}{l}\text { Controlled } \\
\text { startups; gas } \\
\text { monitoring during } \\
\text { mixer pump } \\
\text { operation }\end{array}$ & $\begin{array}{l}\text { S1 } \\
\text { F3 }\end{array}$ & 1 & \\
\hline Composition Change & $\begin{array}{l}\text { What if one pump } \\
\text { fails during } \\
\text { operation? }\end{array}$ & $\begin{array}{l}\text { Would not meet } 90 \% \text { criteria; } \\
\text { insufficient mobilization of } \\
\text { tank waste }\end{array}$ & $\begin{array}{l}\text { Pump instruments } \\
\text { thermocouples, garma } \\
\text { probes }\end{array}$ & $\begin{array}{l}\text { Stop operations } \\
\text { (opt ion; install } \\
\text { another pump). }\end{array}$ & so & $\begin{array}{l}\text { See } \\
\text { remarks }\end{array}$ & $\begin{array}{l}\text { Not binned } \\
\text { because there is } \\
\text { no release. }\end{array}$ \\
\hline More Viscosity & Excess evaporation & $\begin{array}{l}\text { May not be able to mix due to } \\
\text { increased viscosity }\end{array}$ & $\begin{array}{l}\text { Increased load on pump } \\
\text { will be noted if } \\
\text { viscosity increases. } \\
\text { Tank level instruments } \\
\text { and alarms; Tank level } \\
\text { surveillance }\end{array}$ & $\begin{array}{l}\text { Water addition } \\
\text { (e.g., condensate } \\
\text { recycle) }\end{array}$ & $\begin{array}{l}\text { so } \\
\text { F1 }\end{array}$ & $\begin{array}{l}\text { SAME AS } \\
\text { ABOVE. }\end{array}$ & $\begin{array}{l}\text { Significant tank } \\
\text { level decreases } \\
\text { due to } \\
\text { evaporation take } \\
\text { three months. } \\
\text { Not binned } \\
\text { because there is } \\
\text { no release. }\end{array}$ \\
\hline
\end{tabular}


Table 1. Hazard and Operability Study - Node 3 (6 sheets).

\begin{tabular}{|c|c|c|c|c|c|c|c|}
\hline \multicolumn{5}{|c|}{ Project: W-151, Tank 241-AZ-101 Waste Retrieval System Date: 02/14/96 } & \multicolumn{2}{|l|}{ Node: 3} & Page: $3 A-34$ \\
\hline \multicolumn{8}{|c|}{$\begin{array}{l}\text { Node Description: Waste Tank } \\
\text { Design Intention: Encompass tank liquid containment and vapor head space confinement. }\end{array}$} \\
\hline $\begin{array}{l}\text { Parameter/ } \\
\text { Guide word } \\
\end{array}$ & Cause & Consequence & Detection & $\begin{array}{c}\text { Mitigating } \\
\text { Features } \\
\end{array}$ & Rank & $\begin{array}{l}\text { BIN } \\
\text { NO. }\end{array}$ & Remark \\
\hline Criticality & $\begin{array}{l}\text { Rearrangement of } \\
\text { material due to mixer } \\
\text { pump action (and/or } \\
\text { subsequent mixer shut } \\
\text { down) }\end{array}$ & $\begin{array}{l}\text { Release of steam and gases, } \\
\text { aerosols, increased temp., } \\
\text { high activity }\end{array}$ & $\begin{array}{l}\text { Tank temperature and } \\
\text { dome space pressure } \\
\text { instruments and } \\
\text { alarms; ventilation } \\
\text { system instruments and } \\
\text { alarms }\end{array}$ & $\begin{array}{l}\text { Criticality } \\
\text { specifications; }\end{array}$ & $\begin{array}{l}\mathrm{s} 2 \\
\mathrm{~F} 1\end{array}$ & 5 & $\begin{array}{l}\text { Critical Safety } \\
\text { Report WHC-SD- } \\
\text { W151-CSA-001, } \\
\text { "CSER 96-014 } \\
\text { Criticality } \\
\text { Safety of } \\
\text { Project W-151, } \\
241-A Z-101 \\
\text { Retrieval, } \\
\text { System Process } \\
\text { Test," will } \\
\text { evaluate the } \\
\text { critical ity } \\
\text { safety aspects } \\
\text { of the process } \\
\text { test. The } \\
\text { evaluation } \\
\text { extends to the } \\
\text { testing and } \\
\text { operation of the } \\
\text { mixer pumps only } \\
\text { and } \\
\text { does not include } \\
\text { the transfer of } \\
\text { waste from the } \\
\text { tank. The } \\
\text { report provides } \\
\text { justification } \\
\text { that a nuclear } \\
\text { criticality is } \\
\text { extremely } \\
\text { unlikely, if not } \\
\text { impossible, in } \\
\text { this tank. }\end{array}$ \\
\hline More Dome Loading & $\begin{array}{l}\text { Increased load from } \\
\text { newly installed } \\
\text { equipment; } \\
\text { unauthor ized heavy } \\
\text { equipment; dropped } \\
\text { load; } \\
\text { ash, snow and soil } \\
\text { loading }\end{array}$ & $\begin{array}{l}\text { Dome collapse; } \\
\text { loss of conf inement }\end{array}$ & $\begin{array}{l}\text { Visuat survey; } \\
\text { dome space pressure } \\
\text { instruments; stack } \\
\text { flow instruments and } \\
\text { alarms }\end{array}$ & $\begin{array}{l}\text { Administrative } \\
\text { controls (dome } \\
\text { load control } \\
\text { document) }\end{array}$ & $\begin{array}{l}\text { s2 } \\
\text { F2 }\end{array}$ & 4 & \\
\hline
\end{tabular}


Table 1. Hazard and Operability Study - Node 4 (3 sheets).

\begin{tabular}{|c|c|c|c|c|c|c|c|}
\hline \multicolumn{5}{|c|}{ Project: W-151, Tank 241-AZ-101 Waste Retrieval System Date: 02/14/96 } & Node: 4 & & Page: $3 A-35$ \\
\hline \multicolumn{8}{|c|}{$\begin{array}{l}\text { Node Description: Old exhaust ventilation system. } \\
\text { Design Intention: Provide a flow path for the ventilation of the tank and flow of contaminated air to the filters. }\end{array}$} \\
\hline $\begin{array}{l}\text { Parameter/ } \\
\text { Guide word }\end{array}$ & Cause & Consequence & Detection & $\begin{array}{l}\text { Mitigating } \\
\text { Features }\end{array}$ & Rank & $\begin{array}{l}\text { Bin } \\
\text { No. }\end{array}$ & Remark \\
\hline \multirow[t]{6}{*}{ No/Low Flow } & $\begin{array}{l}\text { Blocked valve or } \\
\text { damper }\end{array}$ & $\begin{array}{l}\text { Flammable gas buildup in } \\
\text { vapor space. Potential for } \\
\text { flammable gas burn causing } \\
\text { over pressurization of } \\
\text { filters leading to unfil tered } \\
\text { release. Potential for } \\
\text { pressure release failing } \\
\text { filters when valve opened } \\
\text { resulting in an unfiltered } \\
\text { release }\end{array}$ & $\begin{array}{l}\text { Stack flow instruments } \\
\text { and alarms }\end{array}$ & $\begin{array}{l}\text { Administrative } \\
\text { control of valve } \\
\text { lineup/system } \\
\text { balancing }\end{array}$ & $\begin{array}{l}\mathrm{s} 2 \\
\mathrm{~F} 3\end{array}$ & 1 & \\
\hline & & & $\begin{array}{l}\text { damper position } \\
\text { indication }\end{array}$ & \begin{tabular}{|l|} 
Standby exhaust \\
system; work \\
controls \\
(ventilation \\
system operating \\
during mixer pump \\
operation)
\end{tabular} & $\begin{array}{l}\mathrm{s} 2 \\
\mathrm{~F} 3\end{array}$ & 1 & \\
\hline & & $\begin{array}{l}\text { Diminished cool ing in tank } \\
\text { leading to potential tank } \\
\text { bump which causes over } \\
\text { pressurization of filters } \\
\text { leading to an unfil tered } \\
\text { release. }\end{array}$ & $\begin{array}{l}\text { Exhaust system } \\
\text { instruments and alarms }\end{array}$ & \begin{tabular}{|l|} 
Standby exhaust \\
system; work \\
controls \\
(ventilation \\
system operating \\
during mixer pump \\
EYEPIECE)
\end{tabular} & $\begin{array}{l}\mathrm{S2} \\
\mathrm{F3}\end{array}$ & 1 & \\
\hline & & $\begin{array}{l}\text { Decreased negative pressure } \\
\text { in dome ( } i . e . \text {. ' loss of in } \\
\text { leakage) leading to } \\
\text { unfil tered un-moni tored } \\
\text { release of aerosols or } \\
\text { particulate }\end{array}$ & $\begin{array}{l}\text { Dome space pressure } \\
\text { instruments and alarms }\end{array}$ & \begin{tabular}{|l|} 
Standby exhaust \\
system; work \\
controls \\
(vent ilation \\
system operat ing \\
during mixer pump \\
EYEPIECE)
\end{tabular} & $\begin{array}{l}\mathrm{s2} \\
\mathrm{F} 3\end{array}$ & 1 & \\
\hline & Loss of power & Same as for blocked valve. & $\begin{array}{l}\text { Same as for blocked } \\
\text { valve. }\end{array}$ & $\begin{array}{l}\text { PM (Prevent ive } \\
\text { Maintenance); } \\
\text { standby power }\end{array}$ & $\begin{array}{l}\mathrm{s} 2 \\
\mathrm{~F} 3\end{array}$ & 1 & $\begin{array}{l}\text { Preventative } \\
\text { Maintenance (PM) }\end{array}$ \\
\hline & Seismic event & Same as for blocked valve. & $\begin{array}{l}\text { Same as for blocked } \\
\text { valve. }\end{array}$ & Design features & $\begin{array}{l}\mathrm{s} 2 \\
\mathrm{~F} 1\end{array}$ & 1 & \\
\hline
\end{tabular}


Table 1. Hazard and Operability Study - Node 4 (3 sheets).

\begin{tabular}{|c|c|c|c|c|c|c|c|}
\hline \multicolumn{5}{|c|}{ Project: W-151, Tank 241-AZ-101 Waste Retrieval System Date: 02/14/96 } & Node: 4 & & Page: $3 A-36$ \\
\hline \multicolumn{8}{|c|}{$\begin{array}{l}\text { Node Description: Old exhaust ventilation system. } \\
\text { Design Intention: Provide a flow path for the ventilation of the tank and flow of contaminated air to the filters. }\end{array}$} \\
\hline $\begin{array}{l}\text { Parameter/ } \\
\text { Guide word }\end{array}$ & Cause & Consequence & Detection & $\begin{array}{l}\text { Mitigating } \\
\text { Features }\end{array}$ & Rank & $\begin{array}{l}\text { Bin } \\
\text { No. }\end{array}$ & Remark \\
\hline \multirow[t]{4}{*}{$\begin{array}{l}\text { No/Low Flow } \\
\text { (Cont inued) }\end{array}$} & Fan failure & Same as blocked valve. & $\begin{array}{l}\text { Same as for blocked } \\
\text { valve. }\end{array}$ & $\begin{array}{l}\text { PM; daily } \\
\text { surveillances }\end{array}$ & $\begin{array}{l}\text { s2 } \\
\text { F3 }\end{array}$ & 1 & \\
\hline & stack blockage & $\begin{array}{l}\text { Flammable gases build up and } \\
\text { ignite in tank. The burn } \\
\text { results in pressure build up } \\
\text { which cannot vent due to } \\
\text { plugged stack. The tank } \\
\text { breaches due to over-pressure } \\
\text { releasing contents to soil } \\
\text { column. Potential for } \\
\text { pressure to dislodge plug. } \\
\text { Radionuclides and toxins } \\
\text { released to atmosphere. } \\
\text { Pressurized condition could } \\
\text { occur even without flammable } \\
\text { gas burn. }\end{array}$ & $\begin{array}{l}\text { Same as for blocked } \\
\text { valve }\end{array}$ & $\begin{array}{l}\text { PM; daily } \\
\text { surveillances }\end{array}$ & $\begin{array}{l}\$ 3 \\
\mathrm{~F} 1\end{array}$ & 4 & $\begin{array}{l}\text { Blockage } \\
\text { envisioned to } \\
\text { occur from a } \\
\text { burst HEPA } \\
\text { filter }\end{array}$ \\
\hline & \multirow[t]{2}{*}{$\begin{array}{l}\text { Exhaust HEPA plugged } \\
\text { by aerosols during } \\
\text { mixing }\end{array}$} & $\begin{array}{l}\text { HEPA filter failure due to } \\
\text { high dp leading to unfiltered } \\
\text { release of accumulated } \\
\text { material }\end{array}$ & $\begin{array}{l}\text { Flow indication on } \\
\text { exhaust stack; } \\
\text { HEPA filter dp } \\
\text { instrumentation; } \\
\text { dome space pressure } \\
\text { instruments and alarms }\end{array}$ & $\begin{array}{l}\text { HEPA monitoring } \\
\text { and test ing; } \\
\text { backup HEPA } \\
\text { filters in } \\
\text { paral lel train; } \\
\text { standby exhaust } \\
\text { system }\end{array}$ & $\begin{array}{l}\mathrm{S2} \\
\mathrm{F} 2\end{array}$ & 1 & \\
\hline & & $\begin{array}{l}\text { Unacceptable concentrations } \\
\text { of flammable gases in the } \\
\text { dome space due to inadequate } \\
\text { air removal }\end{array}$ & $\begin{array}{l}\text { Same as HEPA failure } \\
\text { flammable gas } \\
\text { monitoring. }\end{array}$ & $\begin{array}{l}\text { Same as HEPA } \\
\text { failure. }\end{array}$ & $\begin{array}{l}\mathrm{S} 2 \\
\mathrm{~F} 2\end{array}$ & 1 & \\
\hline More Flow & $\begin{array}{l}\text { Ductwork breach from } \\
\text { external phenomena } \\
\text { (seismic event, } \\
\text { vehicle impact, } \\
\text { tornado) }\end{array}$ & $\begin{array}{l}\text { Unfiltered un-monitored } \\
\text { release to the environment }\end{array}$ & $\begin{array}{l}\text { Visual; exhaust stack } \\
\text { flow instruments and } \\
\text { alarms }\end{array}$ & $\begin{array}{l}\text { Administrative } \\
\text { controls; design } \\
\text { of exhaust duct } \\
\text { to withstand } \\
\text { seismic event; } \\
\text { low frequency of } \\
\text { other events }\end{array}$ & $\begin{array}{l}\text { S2 F1 } \\
\text { Seismic } \\
\text { S2 F1 } \\
\text { Vehicle } \\
\text { S2 F0 } \\
\text { Tornado }\end{array}$ & 3 & \\
\hline
\end{tabular}


Table 1. Hazard and Operability Study - Node 4 (3 sheets).

\begin{tabular}{|c|c|c|c|c|c|c|c|}
\hline \multicolumn{5}{|c|}{ Project: W-151, Tank 241-AZ-101 Waste Retrieval System Date: 02/14/96 } & Node: 4 & & Page: $3 A-37$ \\
\hline \multicolumn{8}{|c|}{$\begin{array}{l}\text { Node Description: old exhaust ventilation system. } \\
\text { Design Intention: Provide a flow path for the ventilation of the tank and flow of contaminated air to the filters. }\end{array}$} \\
\hline $\begin{array}{l}\text { Parameter/ } \\
\text { Guide word }\end{array}$ & Cause & Consequence & Detection & $\begin{array}{l}\text { Mitigating } \\
\text { Features }\end{array}$ & Rank & $\begin{array}{l}\text { Bin } \\
\text { No. }\end{array}$ & Remark \\
\hline $\begin{array}{l}\text { More Flow } \\
\text { (Cont inued) }\end{array}$ & Open riser & $\begin{array}{l}\text { Same as Node } 3 \text { Low Negative } \\
\text { Pressure. }\end{array}$ & $\begin{array}{l}\text { Same as Node } 3 \text { Low } \\
\text { Negat ive Pressure. }\end{array}$ & & $\begin{array}{l}\text { s2 } \\
\text { F3 }\end{array}$ & 1 & \\
\hline \multirow[t]{2}{*}{ Reverse Flow } & \multirow{2}{*}{$\begin{array}{l}\text { Pressurization in } \\
\text { interconnected tank } \\
\text { that temporarily } \\
\text { exceeds the exhaust } \\
\text { system negative } \\
\text { pressure }\end{array}$} & Same as Low/No Flow. & $\begin{array}{l}\text { dome space pressure } \\
\text { instruments and alarms }\end{array}$ & Work controls & $\begin{array}{l}\text { s2 } \\
\text { F1 }\end{array}$ & 1 & \\
\hline & & $\begin{array}{l}\text { mixing of gas streams forming } \\
\text { undesirable products }\end{array}$ & $\begin{array}{l}\text { dome space pressure } \\
\text { instruments and alarms }\end{array}$ & Work controls & $\begin{array}{l}\mathrm{S} 2 \\
\mathrm{F1}\end{array}$ & 1 & \\
\hline More Temperature & $\begin{array}{l}\text { See Node } 3 \text { More } \\
\text { Temperature. }\end{array}$ & & & & & & \\
\hline Less Temperature & $\begin{array}{l}\text { Not an issue for this } \\
\text { node. }\end{array}$ & & & & & & \\
\hline More Moisture & $\begin{array}{l}\text { See Node } 3 \text { Vapor Space } \\
\text { Composition Change. }\end{array}$ & & & & & & \\
\hline
\end{tabular}


Table 1. Hazard and Operability Study - Node 5 (3 sheets).

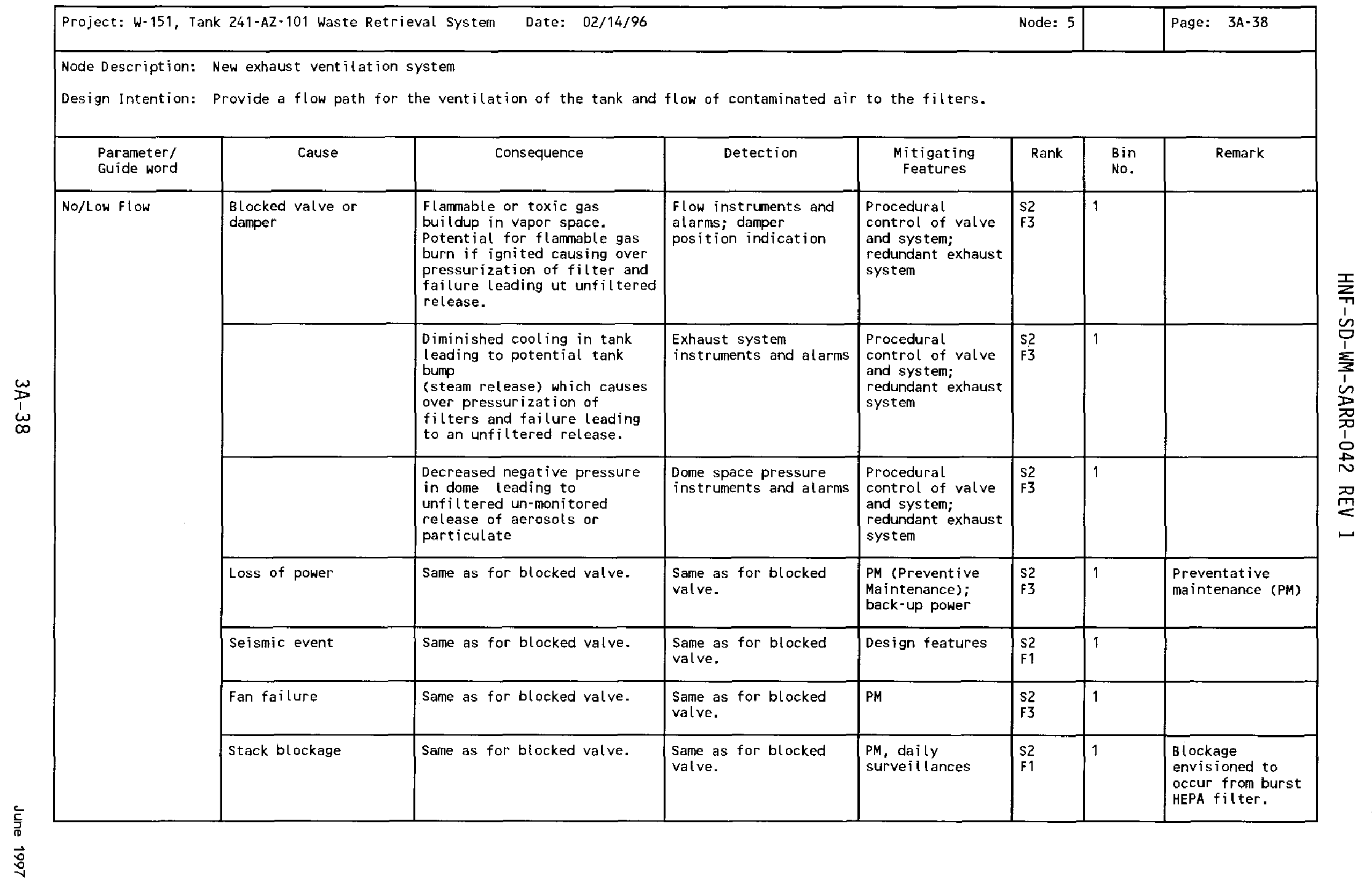


Table 1. Hazard and Operability Study - Node 5 (3 sheets).

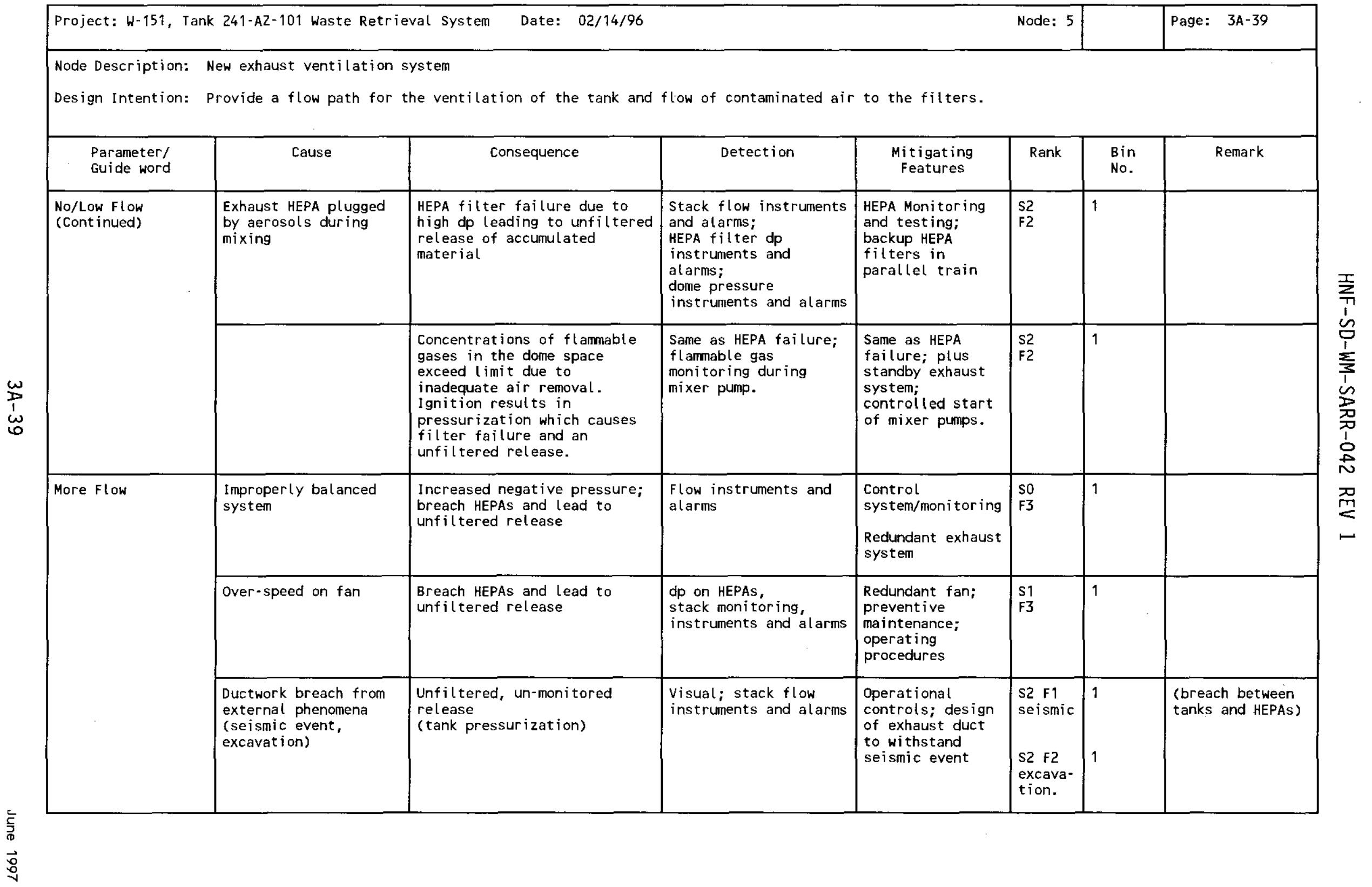


Table 1. Hazard and Operability Study - Node 5 (3 sheets).

\begin{tabular}{|c|c|c|c|c|c|c|c|}
\hline \multicolumn{5}{|c|}{ Project: W-151, Tank 241-AZ-101 Waste Retrieval System Date: 02/14/96 } & \multicolumn{2}{|l|}{ Node: 5} & Page: $3 A-40$ \\
\hline \multicolumn{8}{|c|}{$\begin{array}{l}\text { Node Description: New exhaust ventilation system } \\
\text { Design Intention: Provide a flow path for the ventilation of the tank and flow of contaminated air to the filters. }\end{array}$} \\
\hline $\begin{array}{l}\text { Parameter/ } \\
\text { Guide word }\end{array}$ & Cause & Consequence & Detection & $\begin{array}{l}\text { Mitigating } \\
\text { Features }\end{array}$ & Rank & $\begin{array}{l}\text { Bin } \\
\text { No. }\end{array}$ & Remark \\
\hline $\begin{array}{l}\text { More Flow } \\
\text { (Cont inued) }\end{array}$ & $\begin{array}{l}\text { Open risers (harder } \\
\text { for system to maintain } \\
\text { negative pressure) }\end{array}$ & $\begin{array}{l}\text { Same as for Node } 3 \text { Low } \\
\text { Negat ive Pressure. }\end{array}$ & $\begin{array}{l}\text { Same as Node } 3 \text { Low } \\
\text { Negat ive Pressure. }\end{array}$ & Work controls & $\begin{array}{l}\text { S1 } \\
\text { F3 }\end{array}$ & 2 & \\
\hline Reverse flow & $\begin{array}{l}\text { Pressurization in } \\
\text { interconnected tank } \\
\text { that temporarily } \\
\text { exceeds the exhaust } \\
\text { system negative } \\
\text { pressure }\end{array}$ & $\begin{array}{l}\text { Same as for No/Low flow, } \\
\text { breach HEPAs. }\end{array}$ & $\begin{array}{l}\text { Dome space pressure } \\
\text { instruments and alarms } \\
\text { in tank dome and in } \\
\text { interconnected tank }\end{array}$ & $\begin{array}{l}\text { Controlled } \\
\text { startup of mixer } \\
\text { pump }\end{array}$ & $\begin{array}{l}\text { S1 } \\
\text { F1 }\end{array}$ & 1 & $\begin{array}{l}\text { Consider } \\
\text { backflow } \\
\text { preventer in } \\
\text { tank farm } \\
\text { ventilation } \\
\text { system. }\end{array}$ \\
\hline More Temperature & See Node 3 & & & & & & \\
\hline Less Temperature & Heater shut down & $\begin{array}{l}\text { Excessive moisture buildup in } \\
\text { filters resulting in failure } \\
\text { and potential unfiltered } \\
\text { release }\end{array}$ & $\begin{array}{l}\text { HEPA dp instruments } \\
\text { and alarms across } \\
\text { filters; } \\
\text { flow instruments and } \\
\text { alarms }\end{array}$ & $\begin{array}{l}\text { Redundant exhaust } \\
\text { trains }\end{array}$ & $\begin{array}{l}\text { S1 } \\
\text { F3 }\end{array}$ & 1 & \\
\hline More Moisture & $\begin{array}{l}\text { Same as above. Also, } \\
\text { see Node } 3 \text { Vapor Space } \\
\text { Composition Change }\end{array}$ & & & & & 1 & \\
\hline
\end{tabular}


Table 1. Hazard and Operability Study - Node 6 (2 sheets).

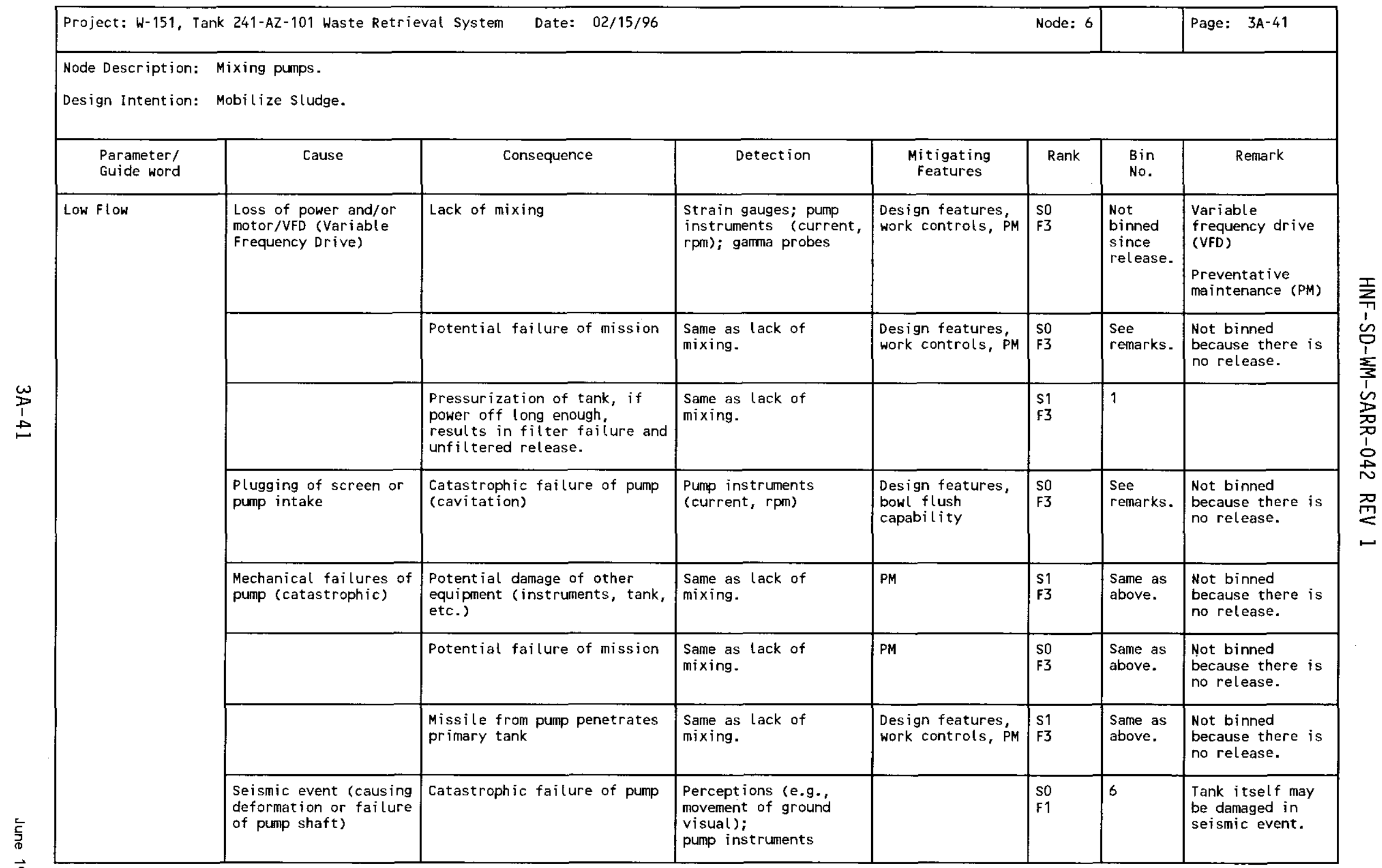


Table 1. Hazard and Operability Study - Node 6 (2 sheets).

\begin{tabular}{|c|c|c|c|c|c|c|c|}
\hline \multicolumn{5}{|c|}{ Project: W-151, Tank 241-AZ-101 Waste Retrieval System Date: 02/15/96 } & Node: 6 & & Page: $3 A-42$ \\
\hline \multirow{2}{*}{\multicolumn{8}{|c|}{$\begin{array}{l}\text { Node Description: Mixing pumps. } \\
\text { Design Intention: Mobilize sludge. }\end{array}$}} \\
\hline & & & & & & & \\
\hline $\begin{array}{l}\text { Parameter/ } \\
\text { Guide word }\end{array}$ & Cause & Consequence & Detection & $\begin{array}{l}\text { Mitigating } \\
\text { Features }\end{array}$ & Rank & $\begin{array}{l}\text { Bin } \\
\text { No. }\end{array}$ & Remark \\
\hline \multirow[t]{2}{*}{$\begin{array}{l}\text { Low Flow } \\
\text { (Cont inued) }\end{array}$} & $\begin{array}{l}\text { Characteristics of the } \\
\text { nonconnective layer } \\
\text { leading to pump } \\
\text { failure or degraded } \\
\text { operation }\end{array}$ & Catastrophic failure of pump & $\begin{array}{l}\text { Pump instruments } \\
\text { (current, rpm) }\end{array}$ & Design features & $\begin{array}{l}\text { so } \\
\text { F2 }\end{array}$ & $\begin{array}{l}\text { See } \\
\text { remarks. }\end{array}$ & $\begin{array}{l}\text { Not binned } \\
\text { because there is } \\
\text { no release. }\end{array}$ \\
\hline & $\begin{array}{l}\text { Foreign object in flow } \\
\text { stream gets past flow } \\
\text { screen }\end{array}$ & $\begin{array}{l}\text { See mechanical failure and/or } \\
\text { plugging. }\end{array}$ & & $\begin{array}{l}\text { Design features } \\
\text { (i.e., screen } \\
\text { wili stop items } \\
\text { which will get } \\
\text { stuck in } \\
\text { impel ler); } \\
\text { work controls } \\
\text { (control led } \\
\text { startup) }\end{array}$ & $\begin{array}{l}\text { s0 } \\
\text { F3 }\end{array}$ & $\begin{array}{l}\text { See } \\
\text { remarks. }\end{array}$ & $\begin{array}{l}\text { Not binned } \\
\text { because there is } \\
\text { no release. }\end{array}$ \\
\hline \multirow[t]{2}{*}{ High flow } & $\begin{array}{l}\text { Pump over-speed due to } \\
\text { viscosity change }\end{array}$ & Tank erosion & $\begin{array}{l}\text { Strain gages, pump } \\
\text { instruments }\end{array}$ & $\begin{array}{l}\text { Control pump } \\
\text { speed; shut pump }\end{array}$ & $\begin{array}{l}\text { so } \\
\mathrm{F} 2\end{array}$ & 4 & \\
\hline & $\begin{array}{l}\text { Variable Frequency } \\
\text { Drive failure (locked } \\
\text { in over-speed) }\end{array}$ & Tank erosion & $\begin{array}{l}\text { Strain gages, pump } \\
\text { instruments }\end{array}$ & Shut down purrip & $\begin{array}{l}\text { so } \\
\text { F3 }\end{array}$ & 4 & \\
\hline
\end{tabular}


Table 1. Hazard and Operability Study - Node 7 (2 sheets).

\begin{tabular}{|c|c|c|c|c|c|c|c|}
\hline \multicolumn{5}{|c|}{ Project: W-151, Tank 241-AZ-101 Waste Retrieval System Date: 05/15/96 } & \multicolumn{2}{|l|}{ Node: 7} & Page: $3 A-43$ \\
\hline \multicolumn{8}{|c|}{$\begin{array}{l}\text { Node Description: Equipment installation and removal. } \\
\text { Design Intention: Worker access to tank during equipment installation and removal; open risers to install and remove equipment. }\end{array}$} \\
\hline $\begin{array}{l}\text { Parameter/ } \\
\text { Guide word }\end{array}$ & Cause & Consequence & Detection & $\begin{array}{l}\text { Mitigating } \\
\text { Features }\end{array}$ & Rank & $\begin{array}{l}\text { Bin } \\
\text { No. }\end{array}$ & Remark \\
\hline \multirow[t]{6}{*}{ High Exposure } & $\begin{array}{l}\text { Removal of } \\
\text { contaminated equipment }\end{array}$ & $\begin{array}{l}\text { Personnel exposure to direct } \\
\text { radiation }\end{array}$ & Dosimetry & \begin{tabular}{|l|} 
Administrative \\
and work controls \\
on installation/ \\
removal \\
activities
\end{tabular} & $\begin{array}{l}\text { s1 } \\
\text { F3 }\end{array}$ & $\begin{array}{l}\text { See } \\
\text { remarks. }\end{array}$ & $\begin{array}{l}\text { Not binned; see } \\
\text { section of test } \\
\text { discussing work } \\
\text { safety. }\end{array}$ \\
\hline & & $\begin{array}{l}\text { Personnel contamination by } \\
\text { direct contact }\end{array}$ & $\begin{array}{l}\text { HPT (Health Physics } \\
\text { Technician) survey }\end{array}$ & $\begin{array}{l}\text { Heal th physics } \\
\text { controls; } \\
\text { decontamination } \\
\text { showers/eyewash } \\
\text { avai lable }\end{array}$ & $\begin{array}{l}\text { S1 } \\
\text { F3 }\end{array}$ & $\begin{array}{l}\text { Same as } \\
\text { above. }\end{array}$ & Same as above. \\
\hline & & Environmental contamination & $\begin{array}{l}\text { HPT survey soil } \\
\text { samples }\end{array}$ & $\begin{array}{l}\text { Plastic sheeting } \\
\text { work controls }\end{array}$ & $\begin{array}{l}\text { s1 } \\
\text { F3 }\end{array}$ & $\begin{array}{l}\text { Same as } \\
\text { above. }\end{array}$ & Same as above. \\
\hline & $\begin{array}{l}\text { Spill from removal of } \\
\text { contaminated } \\
\text { components }\end{array}$ & Environmental contamination & $\begin{array}{l}\text { HPT survey soil } \\
\text { samples }\end{array}$ & $\begin{array}{l}\text { Plastic sheeting } \\
\text { work controls }\end{array}$ & $\begin{array}{l}\text { s1 } \\
\text { F3 }\end{array}$ & $\begin{array}{l}\text { See as } \\
\text { above. }\end{array}$ & Same as above. \\
\hline & & $\begin{array}{l}\text { Personnel exposure to } \\
\text { airborne radioactive material } \\
\text { via re-suspension }\end{array}$ & HPT survey & $\begin{array}{l}\text { Temporary } \\
\text { conf inement such } \\
\text { as greenhouse, } \\
\text { wrapping, } \\
\text { flexible receiver } \\
\text { for equipment } \\
\text { removal }\end{array}$ & $\begin{array}{l}\text { s1 } \\
\text { F3 }\end{array}$ & $\begin{array}{l}\text { Same as } \\
\text { above. }\end{array}$ & Same as above. \\
\hline & $\begin{array}{l}\text { Overflow of waste from } \\
\text { tank }\end{array}$ & See remarks & & & $\begin{array}{l}\text { s2 } \\
\text { F0 }\end{array}$ & & $\begin{array}{l}\text { Not possible to } \\
\text { overflow tank } \\
\text { because the only } \\
\text { additions for } \\
\text { this project are } \\
\text { with spray water } \\
\text { suppl ied from a } \\
4500 \text { gallon tank } \\
\text { truck. }\end{array}$ \\
\hline
\end{tabular}


Table 1. Hazard and Operability Study - Node 7 (2 sheets).

\begin{tabular}{|c|c|c|c|c|c|c|c|}
\hline \multicolumn{5}{|c|}{ Project: $W-151$, Tank 241-AZ-101 Waste Retrieval System Date: 05/15/96 } & \multicolumn{2}{|l|}{ Node: 7} & Page: $3 A-44$ \\
\hline \multicolumn{8}{|l|}{$\begin{array}{l}\text { Node Description: } \\
\text { Design Intention: }\end{array}$} \\
\hline $\begin{array}{l}\text { Parameter/ } \\
\text { Guide word }\end{array}$ & Cause & Consequence & Detection & $\begin{array}{l}\text { Mitigating } \\
\text { Features }\end{array}$ & Rank & $\begin{array}{l}\text { Bin } \\
\text { No. }\end{array}$ & Remark \\
\hline $\begin{array}{l}\text { High Exposure } \\
\text { (Cont inued) }\end{array}$ & $\begin{array}{l}\text { Reversal of air flow } \\
\text { from tank to } \\
\text { atmosphere through } \\
\text { riser during } \\
\text { installation or } \\
\text { removal }\end{array}$ & $\begin{array}{l}\text { Personnel exposure to } \\
\text { airborne contaminants (toxic } \\
\text { gases and radionucl ides) }\end{array}$ & $\begin{array}{l}\text { HPT monitoring; dome } \\
\text { space pressure and } \\
\text { exhaust flow } \\
\text { instruments and alarms }\end{array}$ & $\begin{array}{l}\text { Ventilation } \\
\text { system operating; } \\
\text { work controls }\end{array}$ & $\begin{array}{l}\text { S1 } \\
\text { F3 }\end{array}$ & 2 & \\
\hline \multirow[t]{4}{*}{ High Pressure Leak } & Hose fault & Occupational worker injury & $\begin{array}{l}\text { Visual } \\
\text { High pressure spray } \\
\text { pump instruments }\end{array}$ & $\begin{array}{l}\text { Design features; } \\
\text { work controls; } \\
\text { distance }\end{array}$ & $\begin{array}{l}\text { S1 } \\
\text { F3 }\end{array}$ & $\begin{array}{l}\text { See } \\
\text { remarks }\end{array}$ & $\begin{array}{l}\text { Requires close } \\
\text { proximity to } \\
\text { point of } \\
\text { discharge. Not } \\
\text { binned; see } \\
\text { section of text } \\
\text { discussing } \\
\text { worker safety. }\end{array}$ \\
\hline & $\begin{array}{l}\text { Pump Fault } \\
\text { (catastrophic) }\end{array}$ & Same as hose fault. & $\begin{array}{l}\text { Visual } \\
\text { High pressure spray } \\
\text { pump instruments }\end{array}$ & $\begin{array}{l}\text { Design Features; } \\
\text { work controls; } \\
\text { distance }\end{array}$ & $\begin{array}{l}\text { S2 } \\
\text { F3 }\end{array}$ & $\begin{array}{l}\text { See } \\
\text { remarks. }\end{array}$ & $\begin{array}{l}\text { Not binned; see } \\
\text { section of text } \\
\text { discussing } \\
\text { worker safety. }\end{array}$ \\
\hline & Relief Valve fault & Same as hose fault. & $\begin{array}{l}\text { Visual } \\
\text { High pressure spray } \\
\text { pump instruments }\end{array}$ & $\begin{array}{l}\text { Design Features; } \\
\text { work controls; } \\
\text { distance }\end{array}$ & $\begin{array}{l}\mathrm{S} 2 \\
\mathrm{~F} 3\end{array}$ & $\begin{array}{l}\text { Same as } \\
\text { above. }\end{array}$ & Same as above. \\
\hline & $\begin{array}{l}\text { Variable Frequency } \\
\text { Drive fault (i.e.., } \\
\text { pump over-speed) }\end{array}$ & Same as hose fault. & $\begin{array}{l}\text { Visual } \\
\text { High pressure spray } \\
\text { pump instruments }\end{array}$ & $\begin{array}{l}\text { Design Features; } \\
\text { work controls; } \\
\text { distance }\end{array}$ & $\begin{array}{l}\text { S2 } \\
\text { F3 }\end{array}$ & $\begin{array}{l}\text { Same as } \\
\text { above. }\end{array}$ & Same as above. \\
\hline
\end{tabular}


HNF-SD-WM-SARR-042 REV 1

APPENDIX 3B

HAZARDS ANALYSIS SUMMARY 
HNF-SD-WM-SARR-042 REV 1

This page intentionally left blank. 
Table B1. Hazards Analysis Summary. (5 sheets)

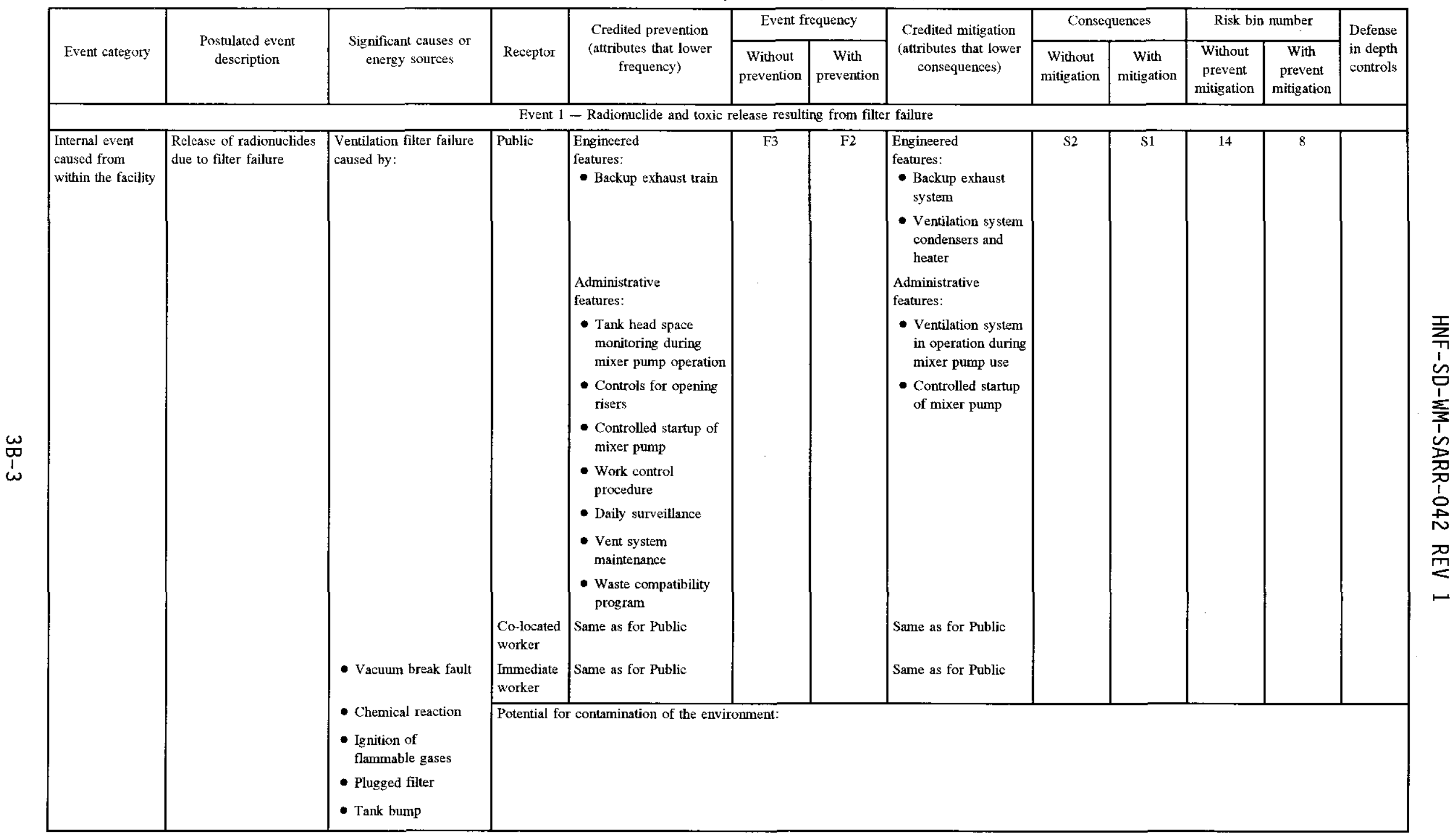


Table B1. Hazards Analysis Summary. (5 sheets)

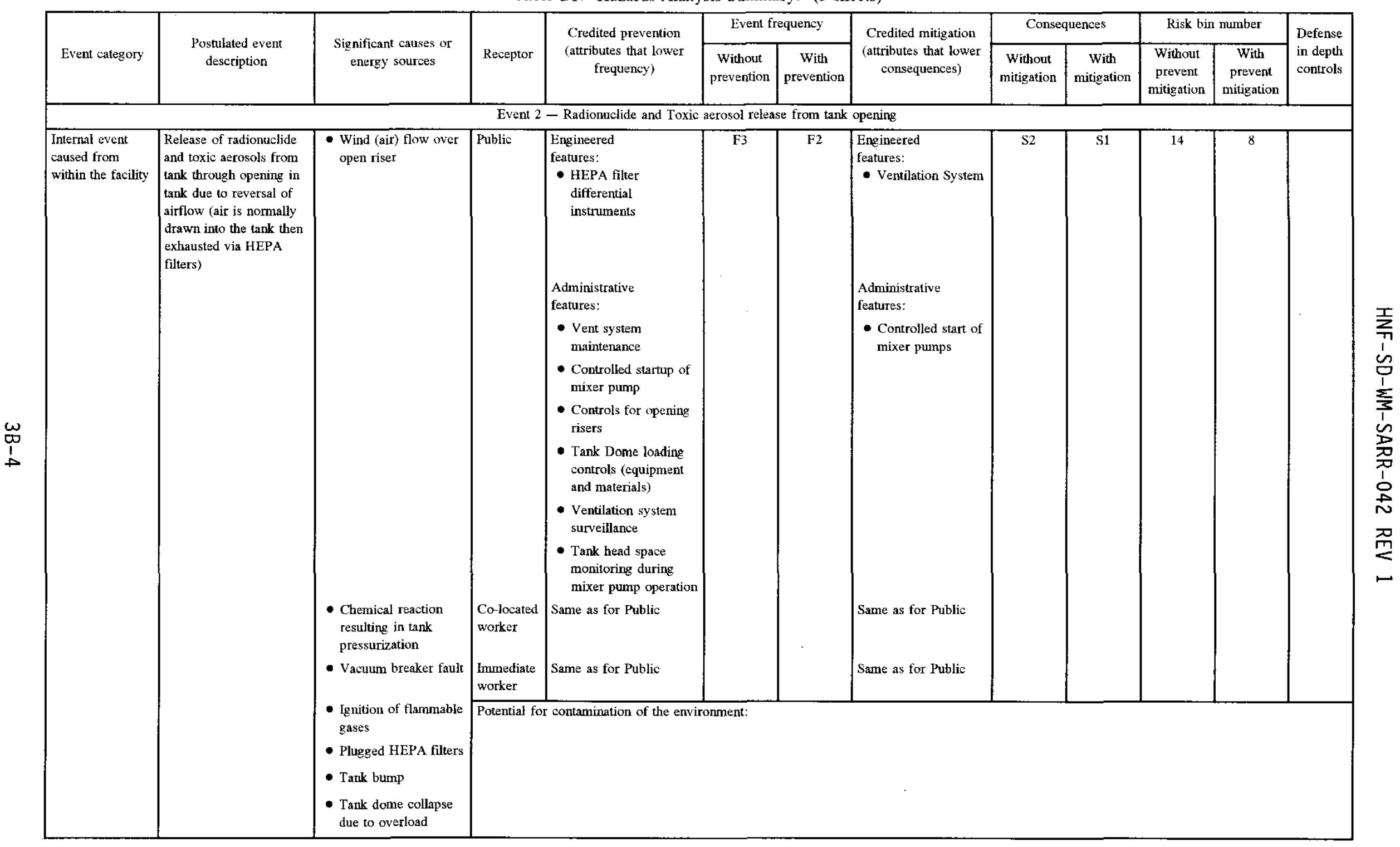


Table B1. Hazards Analysis Summary. (5 sheets)

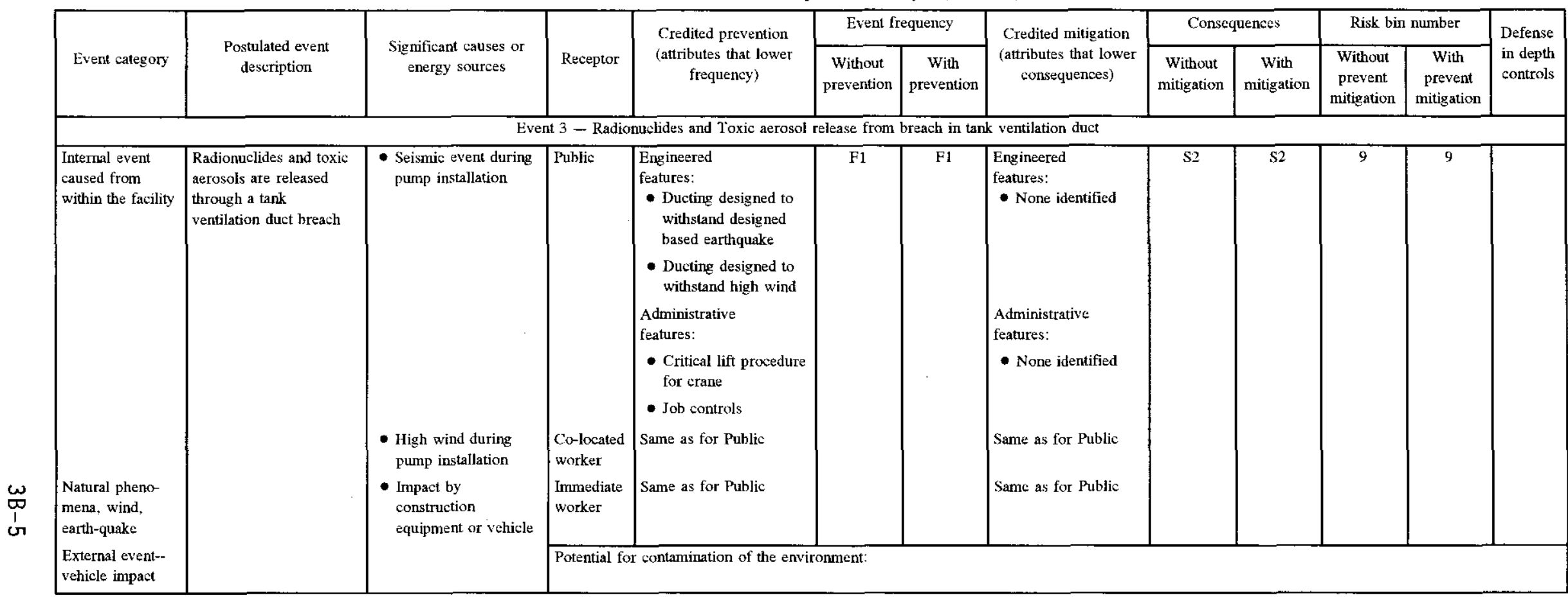


Table B1. Hazards Analysis Summary. (5 sheets)

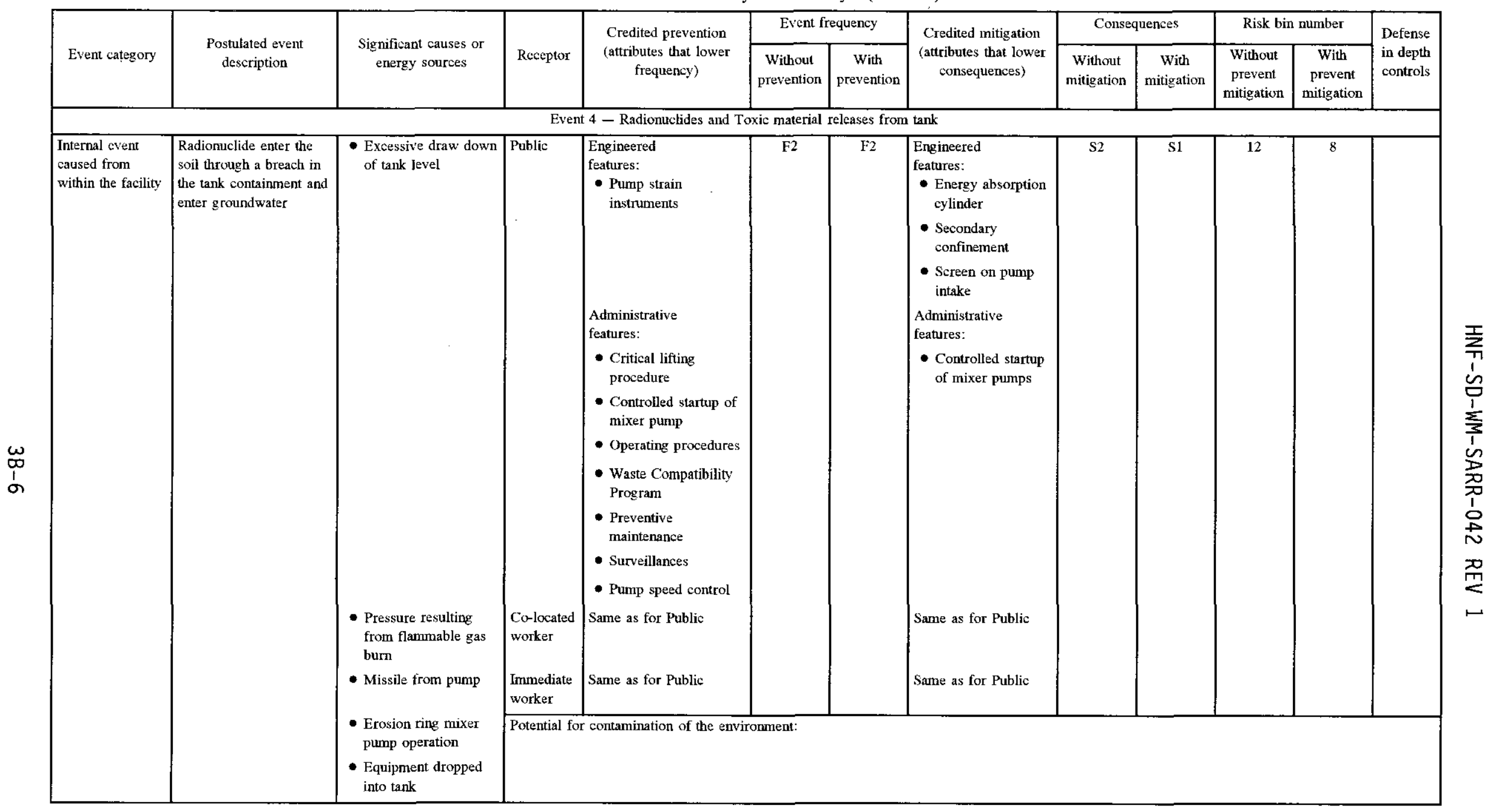


Table B1. Hazards Analysis Summary. (5 sheets)

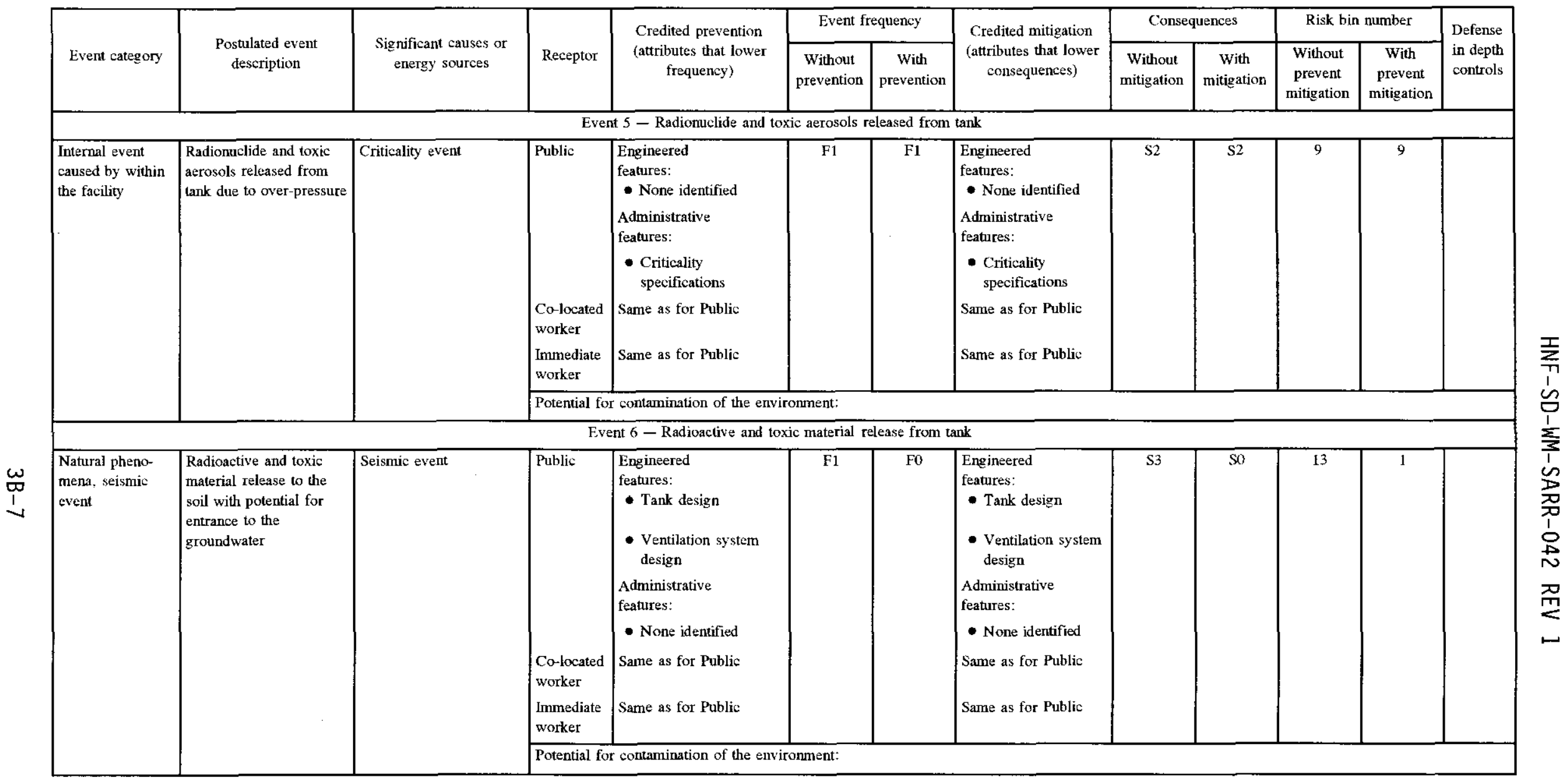


HNF-SD-WM-SARR-042 REV 1

This page intentionally left blank. 


\section{DISTRIBUTION SHEET}

\begin{tabular}{|c|c|c|c|c|c|}
\hline \multirow{2}{*}{$\begin{array}{l}\text { To } \\
\text { Distribution }\end{array}$} & \multirow{2}{*}{\multicolumn{3}{|c|}{$\begin{array}{l}\text { From } \\
\text { E. M. Nordquist }\end{array}$}} & \multicolumn{2}{|l|}{ Page 1 of 1} \\
\hline & & & & \multicolumn{2}{|c|}{ Date June 2, 1997} \\
\hline \multirow{2}{*}{\multicolumn{4}{|c|}{$\begin{array}{l}\text { Project Title/Work Order } \\
\text { Safety Analysis for Tank } 241-A Z-101 \text { Mixer Pump Test } \\
\text { HNF-SD-WM-SARR-042, Revision } 1\end{array}$}} & \multicolumn{2}{|l|}{ EDT No. NA } \\
\hline & & & & \multicolumn{2}{|c|}{ ECN No. 635108} \\
\hline Name & MSIN & $\begin{array}{l}\text { Text } \\
\text { With All } \\
\text { Attach. }\end{array}$ & Text Only & $\begin{array}{l}\text { Attach./ } \\
\text { Appendix } \\
\text { Only }\end{array}$ & $\begin{array}{c}\text { EDT/ECN } \\
\text { Only }\end{array}$ \\
\hline
\end{tabular}

\section{FDH}

S. N. Maruvada

B1-19

C. L. Whaten

H8-67

X

LMHC

D. Alison

S5-03

$T$. L. Bennington

S5-15

M. P. Delozier

S7-84

L. E. Hall

S7-85

M. N. Islam

S5-12

J. G. Kristofzski

R2-12

S5-03

S5- 03

R. K. P'Pool

R2 - 38

R. S. Popielarczyk

S2- -48

W. J. Powell

S7-81

J. L. Rhoades

W. E. Ross

P. L. Smith

G. R. Tardiff

S5-07

R3-01

S5- 05

J. J. Verderber

S5-12

J. H. Wicks

R2-50

NHC

J. N. Alibert

S2-48

S7-82

H6- 35

A. F. Choho

R1-49

J. P. Harris

H5-61

R. P. Marshall

R1-49

P. Mouette

S2-48

E. M. Nordquist

J. E. Van Beek

S2-48

$x(5)$

$x(2)$

H5-61

T. W. Staehr

DESH

W. M. Funderburke

R2-38

G. W. Gault

R1 -44

T. C. Geer

R1 -43

D. M. Hammond

R2-38

C. E. Leach

R1-49

0. M. Serrano

R1-43

$x$

$\begin{array}{ll}\text { A3-88 } & X \\ \text { R1-29 } & X\end{array}$

